\title{
Lithology and hydrothermal alteration control the distribution of copper grade in the Prominent Hill iron oxide-copper-gold deposit (Gawler Craton, South Australia)
}

\section{Journal Article}

Author(s):

Schlegel, Tobias U.; Heinrich, Christoph A. (1)

Publication date:

2015-12

Permanent link:

https://doi.org/10.3929/ethz-b-000109322

Rights / license:

In Copyright - Non-Commercial Use Permitted

Originally published in:

Economic Geology 110(8), https://doi.org/10.2113/econgeo.110.8.1953 
This is the Green Open Access version of: Schlegel T. U. and Heinrich C. A., 2015, Lithology and Hydrothermal Alteration Control the Distribution of Copper Grade in the Prominent Hill Iron OxideCopper-Gold Deposit (Gawler Craton, South Australia): Economic Geology, v. 110, p. 1953-1994.

Original publication see: https://doi.org/10.2113/econgeo.110.8.1953

\title{
Lithology and Hydrothermal Alteration Control the Distribution of Copper Grade in the Prominent Hill Iron Oxide-Copper-Gold Deposit (Gawler Craton, South Australia)
}

\author{
Tobias U. Schlegel1, Christoph A. Heinrich ${ }^{1,2}$
}

${ }^{1}$ Institute of Geochemistry and Petrology, Department of Earth Sciences, ETH Zürich, Clausiusstrasse 25, 8092 Zürich, Switzerland.

${ }^{2}$ Also at: Faculty of Mathematics and Natural Sciences, University of Zürich, 8006 Zürich, Switzerland.

Corresponding author:

Tobias U. Schlegel

E-Mail: tobias.schlegel@erdw.ethz.ch

Phone: +41446323890

Fax: +4144632 1827

\section{Abstract}

The Prominent Hill iron oxide-copper-gold (IOCG) deposit, located in the Gawler craton of South Australia, contains ca. $278 \mathrm{Mt}$ of ore at $0.98 \% \mathrm{Cu}, 0.75 \mathrm{~g} / \mathrm{t} \mathrm{Au}$, and $2.5 \mathrm{~g} / \mathrm{t} \mathrm{Ag}$. In contrast to the predominantly granite-hosted Olympic Dam IOCG deposit, Prominent Hill is mainly within unmetamorphosed sedimentary rocks comprising coarse clastic to laminated argillaceous lithologies with some volcaniclastic components and variable carbonate, including local massive dolomite. Essentially unmetamorphosed sedimentary rocks and structurally underlying mafic to intermediatecomposition lavas, inferred to be members of the lower Gawler Range Volcanics, host the economically mineralized hematite breccias. The volcanic-sedimentary package was downfaulted and tilted along a major E-W fault, north of which similar but regionally low-grade metamorphosed rocks were affected by subeconomic skarn mineralization, and (on a more regional scale of the Mount Woods domain) intruded by granitic and gabbroic bodies. Hydrothermal alteration and mineralization at Prominent Hill involved pervasive and texturally-destructive replacement of formerly calcareous, dolomitic, and siliciclastic breccia components. Hydrothermal alteration minerals comprise hematite, magnetite, siderite, ankerite, quartz, sericite, chlorite, kaolinite, fluorapatite, fluorite, barite, REE-U minerals (including monazite), uraninite, and coffinite, together with $\mathrm{Cu}$ sulfides including chalcopyrite, bornite, and chalcocite in the highest-grade ore.

Brecciation and replacement caused mechanical mixing as well as chemical alteration of primary lithologies, such that sedimentary contacts became obscured. Mass-balance calculations identify Al, $\mathrm{Ti}, \mathrm{Si}$, and $\mathrm{Zr}$ as least-mobile components during hematite-chlorite-sericite to weak hematite-quartz alteration. Because $\mathrm{Zr}$ was not regularly assayed in drill cores, we use concentration ratios of $\mathrm{Ti}, \mathrm{Al}$, and $\mathrm{Si}$ from the deposit-scale assay database to delineate the distribution of lithochemical units prior to hydrothermal alteration and $\mathrm{Cu}$ mineralization. The resulting lithochemical model, based on one horizontal and five vertical cross sections, is used as a basis for mapping alteration patterns calculated 
from molar $(\mathrm{Fe}+\mathrm{Si}) /(\mathrm{Fe}+\mathrm{Si}+\mathrm{Al}), \mathrm{K} / \mathrm{Na}$, and $\mathrm{K} / \mathrm{Al}$ ratios. These chemical patterns, in conjunction with mineral stoichiometry, indicate that the spatial distribution of hematite, chlorite, variably phengitic sericite (and /or illite) \pm kaolinite \pm quartz-bearing alteration is superimposed on the pattern of interpreted lithological contacts. The alteration patterns confirm visual logging results showing that hematite enrichment correlates only partially with the distribution of $\mathrm{Cu}$ grades of $>0.25 \mathrm{wt} \%$. A subvertical body of complete replacement by hematite and quartz with consistent but subeconomic gold enrichment forms a $\mathrm{Cu}$-barren core in the central and eastern parts of the deposit. Zones of increasing $\mathrm{K} / \mathrm{Al}$ and $\mathrm{K} / \mathrm{Na}$ ratios extend upward and westward from this $\mathrm{Cu}$-barren core, transgressively overprinting lithological contacts. The degree of hematite-quartz replacement can be measured by a hematite-quartz alteration index, here termed the $\mathrm{HMSI}$ value $[(\mathrm{Fe}+\mathrm{Si}) /(\mathrm{Fe}+\mathrm{Si}+\mathrm{Al})]$, which inversely correlates with the normal probability for $\mathrm{Cu}$ grade. Areas of highest $\mathrm{Cu}$ grade $(>1 \mathrm{wt} \%)$ spatially correlate with irregular zones having intermediate molar alteration indices: $0.34<\mathrm{K} / \mathrm{Al}<0.40,20<$ $\mathrm{K} / \mathrm{Na}<36$, and $\mathrm{HMSI}<0.98$.

Hematite breccias and $\mathrm{Cu}$ ore deposition developed after tilting of the host sequence into its present steep orientation, as indicated by geopetal structures within the breccia matrix. Thus, the economic mineralization occurred late in the deformational history of the region and after extrusion of the lower Gawler Range Volcanics. The formation of the Prominent Hill orebodies occurred during or after upthrusting of deeper-seated rocks containing subeconomic $\mathrm{Cu}$ in skarns north of the fault. Faulting as well as ore formation may be related to orogenic processes in the central and northern part of the Mount Woods domain. Iron oxide introduction was decoupled from, and at least partly preceded, hydrothermal deposition of high-grade $\mathrm{Cu}$. Geochemical and petrographic data indicate that economic $\mathrm{Cu}$ mineralization occurred together with mildly acidic hematite-chlorite-sericite \pm siderite alteration of originally carbonate-, illite-, and feldspar-bearing sedimentary rocks. The presence of copper enrichment with an intermediate degree of cation leaching from the host rocks indicates that $\mathrm{pH}$ neutralization of initially highly acidic metal-transporting fluids was an essential factor causing $\mathrm{Cu}$ sulfide deposition. Distinct ranges in $\mathrm{Na} / \mathrm{K} / \mathrm{Al}$ ratios and low HMSI values offer potential as exploration indicators pointing towards higher ore grades. These results from Prominent Hill are consistent with recently published mineralogical studies at the giant Olympic Dam deposit, indicating similar ore-depositional controls despite lithologically different host rocks.

Keywords: Prominent Hill, South Australia, iron oxide copper gold (IOCG), Mount Woods inlier, Olympic IOCG province, hematite-quartz alteration, alteration footprint, mobile elements, hematite breccia.

\section{Introduction}

The Olympic Iron Oxide-Copper-Gold (IOCG) province of South Australia (Skirrow et al., 2002; Fig. 1A) hosts the $\mathrm{Cu}-\mathrm{Au} \pm \mathrm{U}$ deposits of Olympic Dam (e.g., Ehrig et al., 2012) and Prominent Hill (Belperio et al., 2007; Freeman and Tomkinson, 2010), as well as more recent discoveries including Carrapateena (Porter, 2010a), Hillside (Conor et al., 2010), and numerous iron oxide prospects containing minor $\mathrm{Cu}$ and $\mathrm{Au}$ (Fig. 1A-C).

The Prominent Hill hematite-associated IOCG deposit is within Precambrian basement of the southern Mount Woods domain and is currently exploited in the Malu open pit, and underground in the Malu and Ankata mines (Fig. 1C). Basement geology of the region (Fig. 1C) is inferred from gravity and aeromagnetic data, and drill hole information, as the deposit is entirely covered by younger strata lying on a Permian erosion surface. The Prominent Hill resource is estimated to contain $278 \mathrm{Mt}$ of ore at $0.98 \% \mathrm{Cu}, 0.75 \mathrm{~g} / \mathrm{t} \mathrm{Au}$, and $2.5 \mathrm{~g} / \mathrm{t} \mathrm{Ag}$ (Freeman and Tomkinson, 2010). Brecciated and mineralized volcanic and sedimentary host rocks experienced intense hematite-quartz and hematite-chloritesericite alteration accompanied by $\mathrm{Cu}-(\mathrm{Fe})$-sulfide, $\mathrm{Au}, \mathrm{U}$, and rare earth element (REE) mineralization (Belperio et al., 2007; Freeman and Tomkinson, 2010). Styles of mineralization include: (a) chalcocite-gold \pm bornite \pm digenite \pm covellite, (b) chalcocite-gold \pm bornite \pm uraninite 


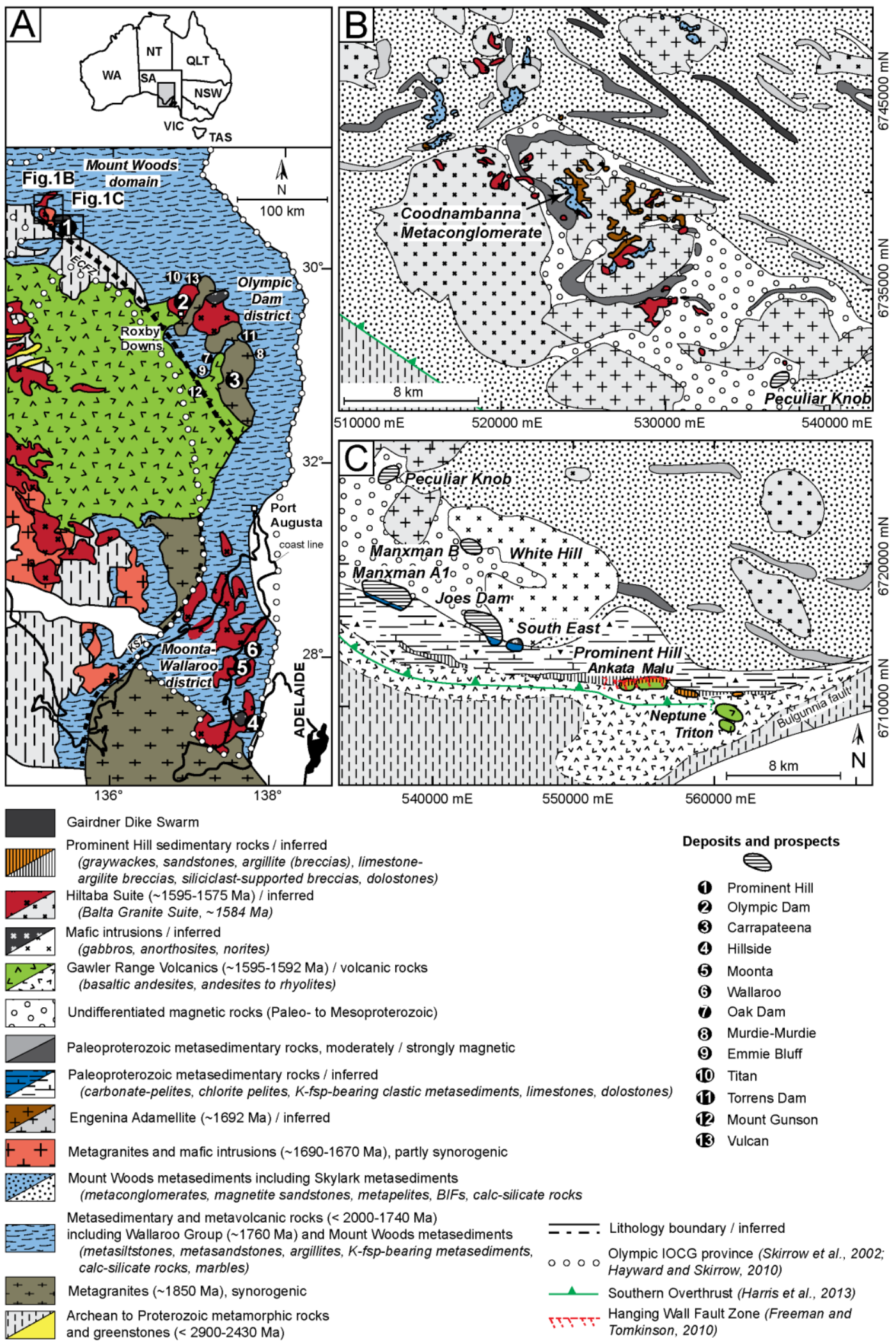

Fig. 1. (A) Interpreted subsurface geology of the eastern Gawler craton showing extent of the Olympic IOCG province, modified from Skirrow et al. (2002), Hayward and Skirrow (2010), and Daly et al. (1998), Ferris et al. (2002), and Hand et al. (2007). (B) Interpreted exposed basement geology of the central and northern Mount Woods domain, underlain by the geophysical interpretation of Betts et al. (2003) (after Forbes et al., 2011). (C) Interpreted subsurface geology of the southern Mount Woods domain, modified from Betts et al. (2003), Freeman and Tomkinson (2010), and Harris et al. (2013). 
\pm fluorite, (c) gold-hematite-quartz-barite, and (d) gold-hematite-carbonate \pm coffinite. The mineralization is generally associated with the hematite breccia matrix. Mineralization styles (c) and (d) occur in distal veins or zones of intense hematite-quartz alteration that contain only low $\mathrm{Cu}$ grades (Belperio et al., 2007).

Although IOCG deposits in the Gawler craton have been a focus of extensive research, their origin and particularly the link among host lithologies, hydrothermal alteration, and $\mathrm{Cu}$ mineralization remains unclear. The Olympic Dam deposit, for example, was discovered using a sediment-hosted, strata-bound $\mathrm{Cu}$ exploration model (Roberts and Hudson, 1983). Subsequent research centered on the magmatic-hydrothermal origin of IOCG deposits in the Gawler craton (Reeve et al., 1990; Oreskes and Einaudi, 1992; Pollard, 2006), but alternative conceptual models include the involvement of nonmagmatic brines with salt components of marine or evaporitic origin (Gow et al., 1994; Haynes et al., 1995; Bastrakov et al., 2007). Research has focused on geochronological constraints (Johnson and Cross, 1995; Skirrow et al., 2007; Ciobanu et al., 2013) and on structural controls of mineralization (Hayward and Skirrow, 2010). However, the possible influence of distinct host rock lithologies and the distribution of iron oxide-bearing alteration in relation to $\mathrm{Cu}$ mineralization have not been studied in detail. At Prominent Hill, the geological factors controlling local $\mathrm{Cu}$ distribution are difficult to recognize because the original character of the host rocks is obscured by intense brecciation and replacement by hydrothermal iron oxides.

In this contribution on Prominent Hill, we present new observations on the geology and lithological structure, and on the hematite-dominant hydrothermal alteration and its relation to $\mathrm{Cu}$ (Fe)-sulfide mineralization, based on petrographic observations and geochemical data. First, the effects of alteration on different lithologies are investigated by sample-scale comparison between altered and mineralized rocks from the mine area with regional background lithologies. Building on previous studies (Belperio, 2002; Carter et al., 2003; Belperio and Freeman, 2004; Belperio et al., 2007; Freeman and Tomkinson, 2010; Harris et al., 2013), petrographic observations provide insight into the formation of the distinctive hematite breccias. These observations serve as a basis for the interpretation of alteration mass balance calculations and support the discrimination between host rock and hydrothermal alteration signatures. Chemical changes are quantified using alteration mass balance calculations (Grant, 1986, 2005; Lopez-Moro, 2012), for: (a) a hematite-chlorite-sericite to hematite-quartz alteration progression, (b) a magnetite-pyrite \pm chalcopyrite \pm quartz alteration sequence, and (c) in individual pairs of least-altered sedimentary host rocks.

Second, these geochemical characteristics are compared to bulk-rock assay data from Prominent Hill, in order to establish a lithochemical model showing the approximate distribution of primary rock types and a superimposed distribution of alteration and mineralization. The lithochemical model is based on ratios for least-mobile elements and their distribution in the Malu deposit area. Combination of the lithochemical model with calculated alteration varieties and their spatial distribution patterns sheds light on how alteration fronts have controlled the local distribution of $\mathrm{Cu}$ grades at Prominent Hill. The geological framework in this paper is the basis for our ongoing project on the deposit, including studies of stable isotopes and fluid chemistry, to be presented in future papers.

\section{Geology of the Olympic IOCG Province}

The Olympic IOCG province (Skirrow et al., 2002) extends through the eastern Gawler craton (e.g., Ferris et al., 2002; Hand et al., 2007). It is bound by the Elizabeth Creek Fault Zone (ECFZ) and the Kalinjala Shear Zone (KSZ) in the west (Fig. 1A) and by the suture of the Gawler craton and the Curnamora craton in the east (Hayward and Skirrow, 2010). Starting at 1900 Ma, rifting-related extension resulted in sedimentation (Hand et al., 2007), the emplacement of the Donington Suite batholith (1850-1730 Ma; Hand et al., 2007), and deposition of the Wallaroo Group sediments and equivalent rocks in the Mount Woods domain between 1790 and 1730 Ma (Conor, 1995; Cowley et al., 2003, Chalmers, 2007). Metasedimentary rocks of the Wallaroo Group are recognized as host 
sequences for some of the IOCG alteration systems in the Olympic IOCG province (Skirrow et al., 2007). These rocks include low-grade metamorphic siltstone, metasandstone interlayered with argillite, alkali-feldspar-bearing metasediments, calc-silicate rocks, and minor calcite and dolomite marbles (Conor, 1995; Cowley et al., 2003).

Between 1604 and 1583 Ma, I- and A-type magmatism formed the Gawler Range Volcanics (GRV; Fanning et al., 1988; Creaser, 1995; Fanning et al., 2007; Allen et al., 2008). The comagmatic (Giles, 1988; Creaser and White, 1991; Creaser, 1996) Hiltaba Suite intrusive rocks were emplaced at generally shallow crustal level between 1595 and 1575 Ma (Fanning et al., 1988; Fanning, 1997; Fanning et al., 2007; Hand et al., 2007). The lower GRV is basaltic to rhyolitic in composition. Thick basalt and andesite flows occur east of the Elizabeth Creek Fault Zone (Fig. 1A; Porter, 2010b). The upper GRV comprises dacitic to rhyolitic lavas. Emplacement of the Hiltaba Suite and GRV was temporally associated with hematite-rich alteration and $\mathrm{Cu}-\mathrm{Au}$ mineralization in the Olympic IOCG province (Ferris et al., 2002; Skirrow et al., 2002, 2007; Ciobanu et al., 2013; Reid et al., 2013). The basement rocks are cut by the Gairdner Dike swarm of Neoproterozoic age ( 827 Ma; Zhao et al., 1994; Wingate et al., 1998), and are partly concealed by Paleozoic and younger siliciclastic strata (Hand et al., 2007).

\section{Geology of the Mount Woods Domain}

The central and northern parts of the Mount Woods domain (also known as Mount Woods inlier; Fig. 1B), include sparsely outcropping Paleo- and Mesoproterozoic metasedimentary rocks, granitoids, and mafic intrusions (Flint and Benbow, 1977; Ambrose and Flint, 1981; Betts et al., 2003; Chalmers, 2007; Freeman and Tomkinson, 2010; Forbes et al., 2011, 2012).

\subsection{Metasedimentary and sedimentary rocks in the Mount Woods domain}

The Skylark metasedimentary rocks are the dominant rocks in the northern and central parts of the Mount Woods domain. They include metaconglomerate, magnetite-bearing metasandstone, quartz- and plagioclase-rich metasandstone, garnet-cordierite-spinel-sillimanite metapelite, quartz-biotite schist, calc-silicate rocks, banded iron formation, and carbonate rocks including marbles and Fe-skarns (Betts et al., 2003; Chalmers, 2007; Freeman and Tomkinson, 2010). A few kilometers north and northeast of Prominent Hill drill cores show magnetite-phlogopite-diopside schist, diopside- and amphibole-bearing metadolostone, K-feldspar-biotite-chlorite-quartzscapolite metasediments, iron-rich carbonate rocks, calc-silicate rocks, marbles, and possible metaevaporites, all metamorphosed to amphibolite facies. These metasedimentary rocks show similarities to the Wandearah Formation, a stratigraphic member of the 1760-1730 Ma Wallaroo Group (Freeman and Tomkinson, 2010). The metasedimentary rocks to the north are separated from unmetamorphosed sedimentary rocks of potentially 1590-1580 Ma depositional age by a reverse fault (Hanging Wall Fault Zone) at Prominent Hill (Belperio et al., 2007; Freeman and Tomkinson, 2010).

No basement rocks crop out in the southern Mount Woods domain (Fig. 1C), thus geological interpretations are based on information from geophysical datasets and exploration drilling (Belperio, 2002; Carter et al., 2003; Belperio et al., 2007; Freeman and Tomkinson, 2010; Harris et al., 2013). Argillaceous, calcareous, and siliciclastic rocks dominate in drill cores. These lithologies are identified in variable proportions in prospects to the east (e.g., Proteus, Caliban) and extend across Prominent Hill towards the west into the area of the Joe`s Dam and Joe`s Dam South East (SE) prospects, and possibly beyond (Fig. 1C).

\subsection{Volcanic rocks in the Mount Woods domain}


Southeast of Prominent Hill, the Neptune and Triton prospects (Fig. 1C; Freeman and Tomkinson, 2010) are located in largely undeformed and auto-brecciated lava flows and sub-volcanic stocks or sills. These magmatic rocks have been correlated with the GRV (Carter et al., 2003; Harris et al., 2013). South of Prominent Hill, the lavas are predominantly mafic and range in composition from basalt to andesite. Towards the west, felsic compositions become more abundant, and dacite and rhyolite are both present. The lavas extend for at least $20 \mathrm{~km}$ along the southern boundary of the Mount Woods inlier (Freeman and Tomkinson, 2010) and are cut by the Southern Overthrust and associated substructures (Harris et al., 2013; Fig. 1C).

\subsection{Relationships among metasedimentary rocks, intrusion, metamorphism, and exhumation}

Detrital zircons in the Skylark metasediments (Fig. 1B) exhibit U-Pb age peaks at $\sim 1850 \mathrm{Ma}$ and $\sim 1750 \mathrm{Ma}$ (Chalmers, 2007). They show a similar age distribution as that of the Wandearah Formation and a volcaniclastic sandstone of the Moonabie Formation, both of which are members of Wallaroo Group metasedimentary rocks of the southwestern Gawler craton. During the Kimban orogeny (1730-1690 Ma), the Skylark metasedimentary rocks were metamorphosed to granulite facies in the north and to amphibolite facies further south (Betts et al., 2003; Chalmers, 2007; Jagodzinski et al., 2007; Freeman and Tomkinson, 2010). The metasediments were intruded by the syn-orogenic Engenina Adamellite at $1692 \pm 25$ Ma (SHRIMP U-Pb zircon ages; Fanning, 1997; Daly et al., 1998; Betts et al., 2003). Magnetite-bearing metasandstones are unconformably overlain by lower metamorphic grade and hematite matrix-bearing Coodnambana metaconglomerate, showing a detrital zircon population of U-Pb ages like those of the underlying Skylark metasediments, but also Hiltaba-GRV-age metamorphic zircon rims with ages of $1595 \pm 10 \mathrm{Ma}$ (SHRIMP U-Pb; Chalmers, 2007). The unconformity indicates that the Skylark metasedimentary rocks were exhumed after the Kimban orogeny (Betts et al., 2003), overlain by the Coodnambana metaconglomerate, and then reburied (Chalmers, 2007). After this cycle, the metasediments were intruded by the Balta Granite (Hiltaba Suite) at $1584 \pm 18 \mathrm{Ma}$ (U-Pb zircon; Fanning, 1997). Apparently contemporaneous gabbroic rocks occur in the White Hill mafic igneous complex (Chalmers, 2007; Freeman and Tomkinson, 2010)

and at Peculiar Knob (Fig. 1B) where a leucogabbro crystallized at $1587 \pm 3 \mathrm{Ma}$ (U-Pb zircon; Jagodzinski, 2005). A dacite porphyry in the hanging wall of the Prominent Hill deposit has a U-Pb zircon age of $1585 \pm 8 \mathrm{Ma}$ (Belperio et al., 2007).

Several stages of continuous metamorphism (Forbes et al., 2011) at $\sim 1658, \sim 1615$, and $\sim 1576$ $\mathrm{Ma}$, or even later, thus overlapping with Hiltaba-GRV times, are indicated by diverse geochronological data. These include ages for metamorphic quartzite recrystallization at 1658 (Holm, 2004), metamorphic monazite growth at $\sim 1615 \mathrm{Ma}$ (EMPA U-Pb, Forbes et al., 2011) in the central Mount Woods inlier, 1595 Ma zircon rims in the Coodnambana metaconglomerate (Chalmers, 2007), and formation of contact-metamorphic zircon rims at $1576 \pm 7$ Ma at Peculiar Knob (SHRIMP U-Pb, Jagodzinski, 2005). The Mount Woods inlier was affected by a major thermal event that occurred after the Skylark metasedimentary rocks were reburied (Chalmers, 2007; Forbes et al., 2011, 2012). Exhumation of the Mount Woods inlier started between 1592 and 1582 Ma (Forbes et al., 2012) during compression, and was localized along a series of reverse faults including the Southern Overthrust (Betts et al., 2003; Forbes et al., 2012; Harris et al., 2013).

\section{Regional Alteration in the Central and Southern Mount Woods Domain}

Outcrops and drill cores from the central Mount Woods domain record widespread hydrothermal alteration (Hampton, 1997; Freeman and Tomkinson, 2010). At Joe's Dam (Fig. 1C), early Na-Ca-Fe alteration with albitization, formation of calc-silicates (actinolite and diopside) and 
magnetite was followed by brecciation and late infill by magnetite, pyrite, and chalcopyrite (Freeman and Tomkinson, 2010). Intensity of iron oxide-rich alteration can vary within a few meters and entirely change the appearance of a rock, without any brecciation visible in hand specimen. Two main styles of iron oxide-dominant alteration are abundant in the region, one characterized by abundant magnetite and the other by abundant hematite.

\subsection{Magnetite-dominant alteration}

Magnetite \pm phlogopite and/or magnetite-K-feldspar-pyrite \pm chalcopyrite \pm pyrrhotite \pm apatite \pm titanite \pm monazite alteration affected both metasedimentary and volcanic rocks. Repeated magnetite and pyrite-rich alteration is widespread and occurred before, during, and after brecciation (Fig. 2). The alteration assemblage is locally associated with low $\mathrm{Cu}$ grades derived from minor chalcopyrite.
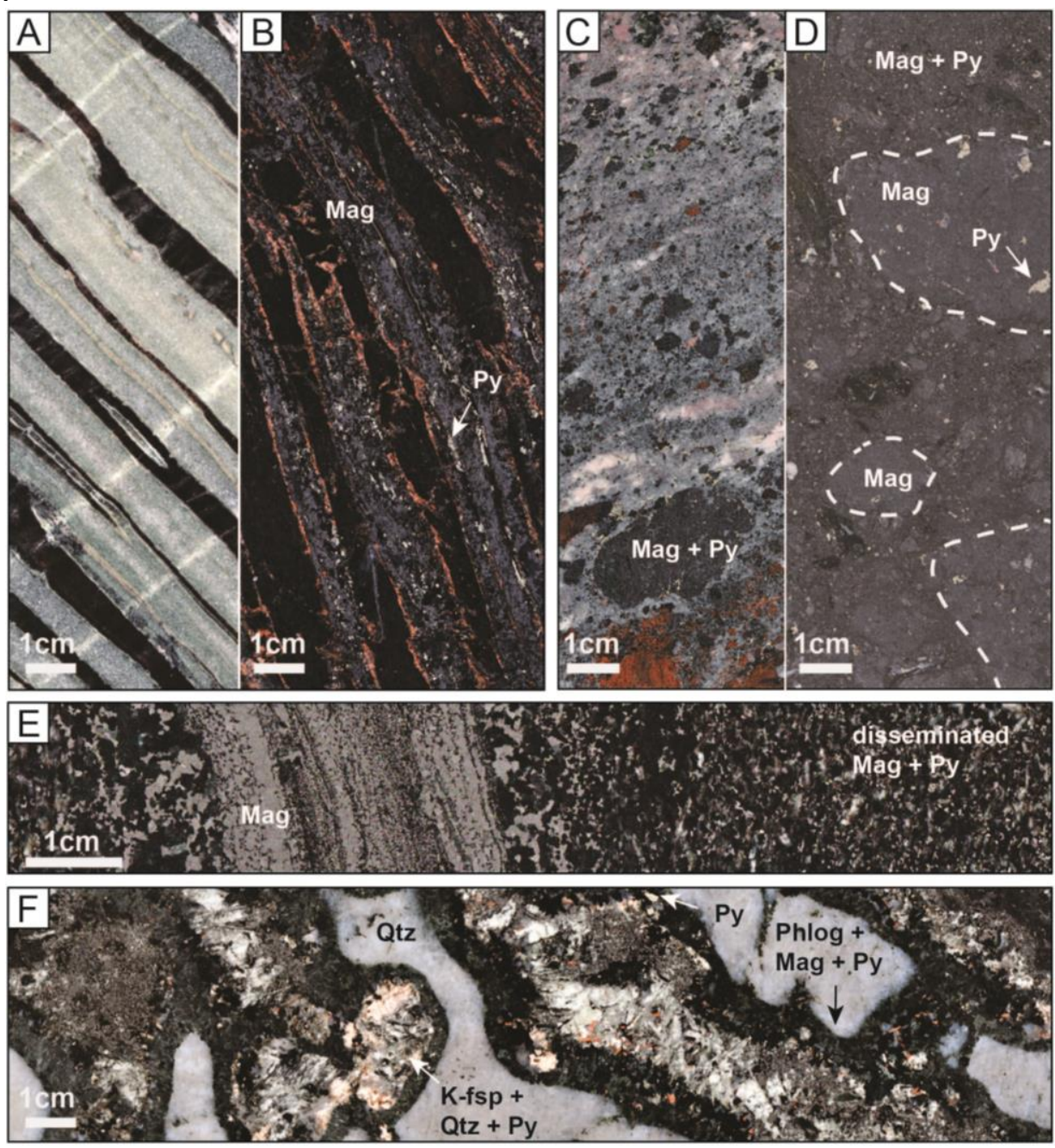

Fig. 2. Regional magnetite-pyrite-rich alteration of (A-D) sedimentary rocks and (E, F) igneous rocks at the Joe's Dam South East prospect. (A) Least-altered limestone-pelite unit, DD11JDMSE001, $391.7 \mathrm{~m}$. (B) Magnetite-pyrite-altered limestonepelite equivalent, DD11JDMSE001, $278.7 \mathrm{~m}$; note that calcareous beds in (A) appear as magnetite and pyrite in (B). (C-D) Two cycles of magnetite-phlogopite-pyrite alteration separated by a period of brecciation. (C) Sub-rounded magnetitephlogopite-pyrite clasts in calcareous breccia matrix show that early magnetite-pyrite alteration occurred prior to brecciation, DD11JDMSE003 $112.4 \mathrm{~m}$. (D) Subsequent magnetite-pyrite replacement of breccia matrix; remnants of earlier alteration are visible as dense magnetite-phlogopite-pyrite clasts (outlined by white dashed lines), DD11JDMSE003, 115.7 m. (E) Disseminated magnetite-pyrite-bearing gabbro showing magnetite bands, DD11JDMSE002, 336.9 m. (F) K-feldsparphlogopite-magnetite-quartz and pyrite-bearing exsolutions in gabbro, DD11JDMSE002, 304.2 m. Mineral abbreviations: K-fsp, K-feldspar; Mag, magnetite; Phlog, phlogopite; Py, pyrite; Qtz, quartz. 
Adjacent to the White Hill mafic intrusive complex (Fig. 1C), contact metamorphism associated with hydrothermal alteration and magmatic fluid expulsion is recorded by the distribution of magnetite-rich metasedimentary rocks (Betts et al., 2003), magnetite- and pyrite-bearing miarolitic cavities in gabbroic rocks (Fig. 2), and veins that cut metasedimentary rocks at Joe's Dam South East (Fig. 1B).

At Joe's Dam South East, interbedded limestone-pelite (Fig. 2A) and its brecciated equivalents contain a magnetite \pm pyrite \pm quartz assemblage that pervasively replaces calcareous beds (Fig. 2B). This alteration occurred in individual stages separated by brecciation (Fig. 2C) and renewed replacement of the calcareous breccia matrix by magnetite and pyrite (Fig. 2D). A spatial relationship between the extent of alteration minerals is indicated in magnetite-phlogopite-pyrite altered rocks. Drill hole DD11JDMSE002, collared at the boundary of the White Hill mafic intrusive complex (Fig. 1B), intersects gabbro showing magnetite banding (Fig. 2E). Intervals in this drill core contain Kfeldspar-phlogopite-magnetite-quartz \pm pyrite \pm pyrrhotite in miarolitic cavities (Fig. 2F). Farther down the hole, K-feldspar-, quartz-, and pyrite-bearing pegmatitic veins cut the deformed interbedded limestone-pelite unit. In drill hole DD11JDMSE001, collared $100 \mathrm{~m}$ to the south, this unit displays increasing amounts of pyrite in calcareous layers that grade into dominantly magnetitepyrite \pm phlogopite-altered interbedded limestone-pelite (Fig. 2B). Farther downhole, weakly altered host rock is mostly absent and massive magnetite-pyrite \pm chalcopyrite replaces the sedimentary protolith. In a $35 \mathrm{~cm}$-thick interval, disseminated calcite, interpreted to be primary, is still visible. The magnetite-pyrite rock is followed by brecciated limestone-pelite, again showing magnetite-poor but some pyrite-rich calcareous beds. These observations demonstrate that hydrothermal pyrite locally extends beyond the limits of hydrothermal magnetite.

\subsection{Hematite-dominant alteration}

Hematite-dominant alteration overprints albite- and magnetite-K-feldspar-altered, undeformed, porphyritic to aphyric basaltic andesitic and andesitic GRV lavas (Carter et al., 2003; Harris et al., 2013) at the Triton prospect (Fig. 1B). The alteration resulted in small-scale re-brecciation and pseudo-brecciation by replacement (Fig. 3). The hematite-chlorite-sericite-kaolinite-fluorite (Fig. 3A-E) to hematite-quartz-apatite-barite alteration sequence (Fig. 3D-F) documents how increasing alteration intensity affected a $\sim 10$ m-long interval of unbrecciated andesite. This interval lacks lithological contacts. Early crystallized amphibole is replaced by chlorite, and is overgrown by euhedral plagioclase phenocrysts that in turn are progressively altered to sericite and chlorite (Figs. 3A-C, 4A). The transition to hematite-quartz alteration resulted in pseudo-brecciation (Fig. 3D-E) and nearly complete replacement of the original rock (Fig. 3F) and destruction of mineral textures (Fig. 4B-D). In this alteration stage, kaolinite is intergrown with sericite (Fig. 4C, left) and replaces plagioclase crystals or infills volcanic amygdales (Fig. 4C, left). Intense hematite-quartz \pm apatite \pm barite alteration (Figs. 3E-F, 4D) led to replacement of feldspars (Fig. 4D) and sericite-kaolinite-filled amygdales (Fig. 4C, right). Late calcite fills remaining pores (Fig. 3F). 

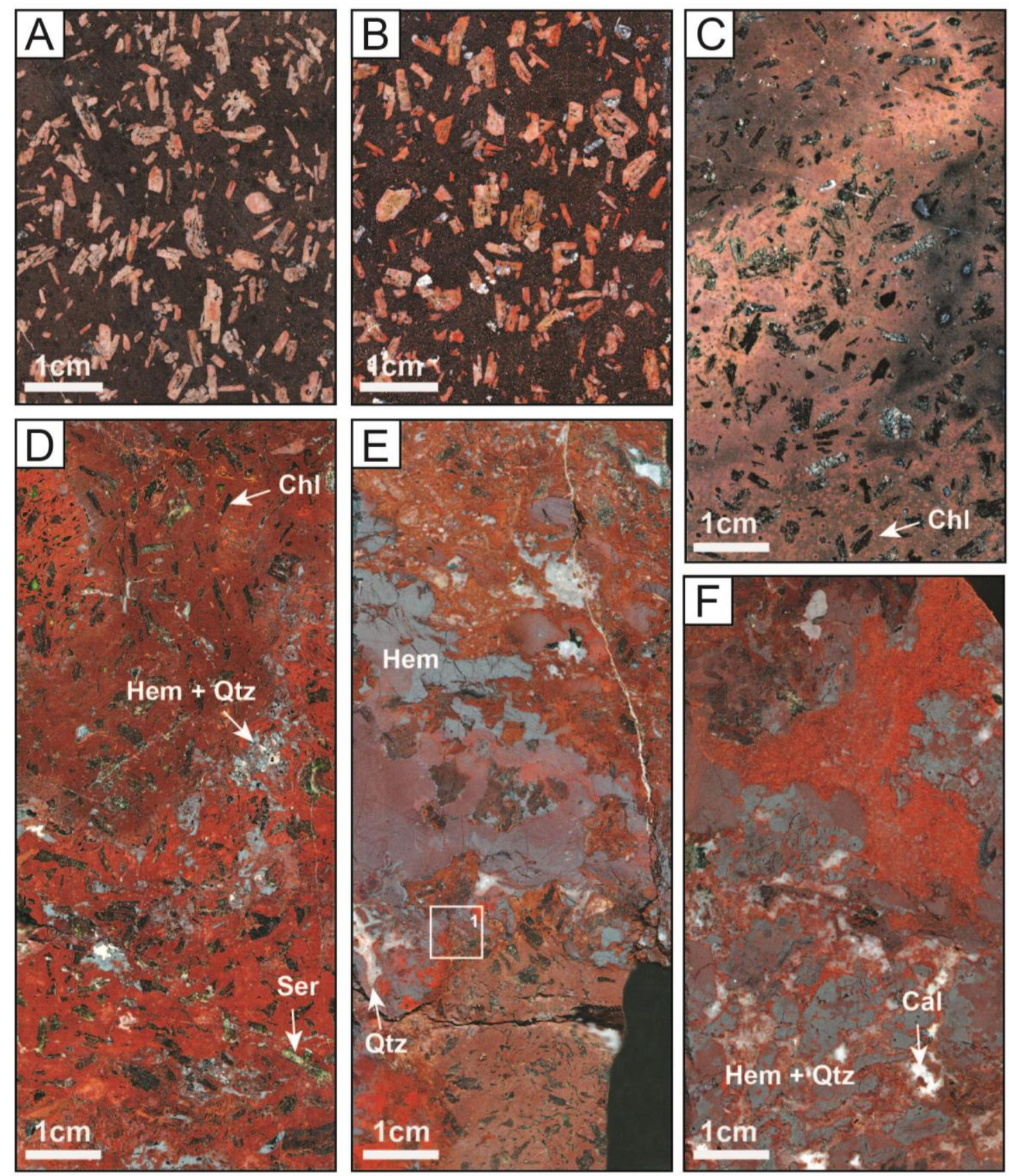

Fig. 3. Regional iron oxide alteration of volcanic rocks in drill hole DD09TRI006 from the Triton prospect. Photographs of rock slabs show progressive of a plagioclase-phyric andesite from hematite-chlorite-sericite-fluorite-barite-kaolinite to hematite-quartz-fluorapatite-barite assemblages. (A) Optically equivalent sample to least-altered andesite precursor, $203.7 \mathrm{~m}$. (B) Hematite-chlorite to sericite-altered plagioclase phenocrysts, $204.8 \mathrm{~m}$. (C) Plagioclase crystals are nearly completely altered to chlorite and sericite, $209.2 \mathrm{~m}$. (D) Chlorite-sericite-kaolinite-bearing example of hematite-quartz alteration replacing plagioclase-phyric volcanic rock, $214.2 \mathrm{~m}$. (E) Pseudo-brecciated interval showing hematite- and quartz-replaced rock next to chlorite- and sericite-altered patches, $212.4 \mathrm{~m}$ (box 1 refers to Fig. 4D). (F) Nearly complete replacement of andesite by hematite-quartz alteration; remnants of original rock texture may be identified in upper left, 213.2 m. Mineral abbreviations: Cal, calcite; Chl, chlorite; Hem, hematite; Qtz, quartz; Ser, sericite. 

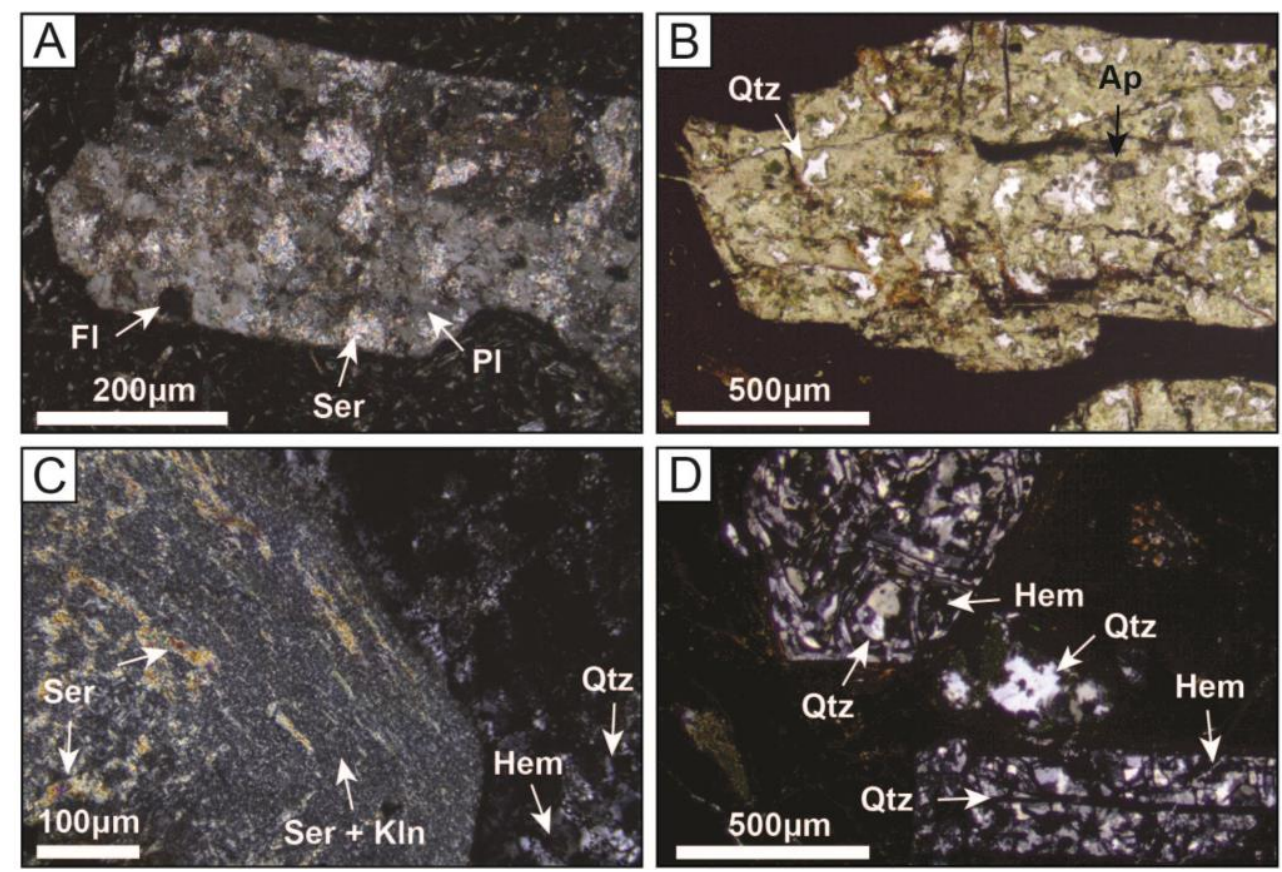

Fig. 4. Photomicrographs showing regional iron oxide alteration by grain-scale replacement of plagioclase-phyric andesite from drill hole DD09TRI006 at Triton prospect. (A) Partly sericite-fluorite-altered plagioclase in medium-grained, feldsparbearing groundmass; cross-polarized light, $203.7 \mathrm{~m}$. (B) Chlorite-sericite-quartz-fluorapatite-altered plagioclase crystals, polarized light, $141.2 \mathrm{~m}$. (C) Volcanic amygdale filled with intergrown sericite and kaolinite (left) that are both replaced by quartz and hematite (right); cross-polarized light, $141.2 \mathrm{~m}$. (D) Near-complete replacement of plagioclase by hematite and quartz, cross-polarized light, $212.4 \mathrm{~m}$. Mineral abbreviations: Ap, apatite; Chl, chlorite; Hem, hematite; Kln, kaolinite; Pl, plagioclase; Qtz, quartz; Ser, sericite.

\section{Geology of the Prominent Hill Deposit}

This section summarizes and complements the deposit geology of Prominent Hill (Fig. 5) as outlined by previous research (Belperio, 2002; Carter et al., 2003; Belperio and Freeman, 2004; Belperio et al., 2007; Freeman and Tomkinson, 2010).

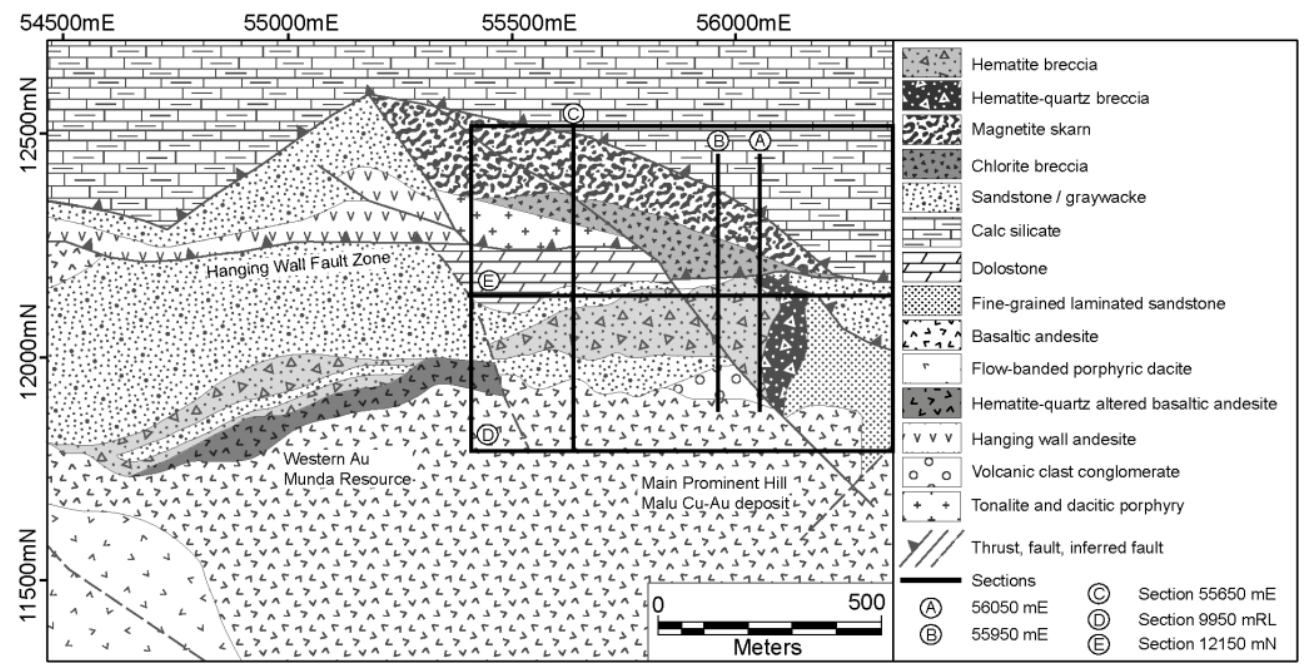

Fig. 5. Simplified geological map of the Prominent Hill deposit area below Phanerozoic cover. A-E mark positions of Prominent Hill type sections mentioned in the text. Section $9950 \mathrm{mRL}$ (D) is located approximately $150 \mathrm{~m}$ below the basement-cover unconformity (modified from Freeman and Tomkinson, 2010). 


\subsection{General structure and major lithologies}

Below the Phanerozoic cover, greenschist-facies metasedimentary and unmetamorphosed sedimentary rocks are separated by an east-west trending, variable steeply north-dipping chlorite breccia, representing the Hanging Wall Fault Zone (HWFZ, Fig. 5). The HWFZ probably is a north-sideup reverse fault (Belperio et al., 2007), with unknown displacement (Freeman and Tomkinson, 2010). North of the HWFZ (in the hanging wall), the metasedimentary rocks are intruded by undeformed granitoids including a 1585 Ma dacite porphyry (Belperio et al., 2007). South of the HWFZ (in the footwall), the sedimentary rocks are bound by a possible unconformity (Freeman and Tomkinson, 2010, Fig. 3, p. 175) to structurally underlying mafic to intermediate-composition lower GRV (Belperio et al., 2007). The sedimentary and volcanic rocks in the footwall host economic $\mathrm{Cu}$ and $\mathrm{Au}$ mineralization, overprinting earlier hydrothermal hematite replacement zones (see below).

Calcareous clastic metasedimentary rocks and granitoids north of the HWFZ: The mostly unbrecciated metasedimentary rocks include carbonate-pelite, chloritic pelite, and K-feldsparbiotite-chlorite-quartz-scapolite clastic metasediments, limestone and dolostone, and possible former evaporites (Freeman and Tomkinson, 2010). Reddish granitoids are quartz-diorite, tonalite, and a felsic K-feldspar-phyric porphyry showing fine-grained dusting by hematite (Belperio et al., 2007).

Sedimentary host rocks south of the HWFZ: The sedimentary host rocks consist of interbedded and brecciated, argillaceous dolostone, argillite (breccias), calcareous matrix-bearing and coarsegrained siliciclastic, clast-supported breccias, medium- to fine-grained graywacke, chlorite- and muscovite-cemented sub-arkose, and laminated and massive limestone and dolostone, as well as quartz-feldspar conglomerate and volcanic-clast conglomerate south of the deposit (Belperio and Freeman, 2004; Belperio et al., 2007; Freeman and Tomkinson, 2010). In addition, brecciated or interbedded limestone-argillite occurs west of the Ankata mineralization (Fig. 1C). The sedimentary rocks appear tabular and dip steeply to the north at Prominent Hill. Breccias are strata-bound and mainly single-stage (Freeman and Tomkinson, 2010), with little evidence of re-fracturing of previously consolidated breccia. Variable brecciation intensity resulted in the formation of clast- or matrix-supported breccia sheets. Sharp breccia contacts are indicated by a sudden change of clast size or type. The brecciation predates the hematite-dominant replacement in the footwall (see below).

Volcanic rocks south of the HWFZ: The volcanic rocks consist of massive or amygdaloidal, plagioclase-phyric basaltic andesite, andesite, and minor dacite. Locally, andesite flows are interlayered with volcaniclastic rocks including lapilli tuff, agglomerate (Belperio et al., 2007), calcareous argillite, and sandstone structurally above.

Pre-mineralization mafic to intermediate-composition and post-mineralization mafic sills and dikes: The hematite-altered sedimentary host rocks are cut by generally unbrecciated basalticandesitic, andesitic, and dioritic sills and dikes that are altered to sericite, chlorite, or hematite. Some of these rocks contain chalcopyrite in the sericite-rich matrix and have sparse amygdules composed of fluorite, barite, and siderite. However, chilled margins are not abundant in the inspected drill core. The latest diabase dikes clearly postdate mineralization, and cut all hanging wall and footwall lithologies; these dikes may represent equivalents of the Gairdner Dike swarm (Freeman and Tomkinson, 2010).

\subsection{Hydrothermal iron oxide alteration varieties, mineralization, and relative timing}

Magnetite skarn north of the HWFZ: The metasedimentary rocks in the hanging wall of the HWFZ are altered to a skarn-like mineral assemblage of magnetite-phlogopite-chlorite-pyrite \pm chalcopyrite \pm actinolite-tremolite \pm serpentine \pm talc \pm scapolite (Freeman and Tomkinson, 2010). Pyrite is abundant and locally reaches up to $20 \mathrm{vol} \%$ (Belperio and Freeman, 2004), but $\mathrm{Cu}$ grade is typically below $0.2 \%$. It is unclear if this magnetite skarn represents a single alteration event or the 
result of episodic Fe $\pm \mathrm{K} \pm \mathrm{Mg}$ alteration, as observed in the Joe’s Dam South East prospect (Fig. 2). Drill holes in the Malu pit area show a variably thick band of martite (hematite pseudomorphs after magnetite) immediately north of the HWFZ. Magnetite skarn zones are separated by meter-scale layers of chlorite breccia, granitoids, and local fault zones. Magnetite-quartz-calcite-fluorite-barite \pm pyrite \pm chalcopyrite veins cut all hanging wall lithologies. Calcite-quartz \pm hematite \pm fluorite \pm chalcopyrite veins have been correlated to the $\mathrm{Cu}$ mineralization in the footwall (Belperio et al., 2007). This, together with the formation of martite, indicates that the magnetite skarn formation predated the hematite-associated economic $\mathrm{Cu}$ mineralization. Veins containing chalcopyrite are common but volumetrically minor within the magnetite skarn.
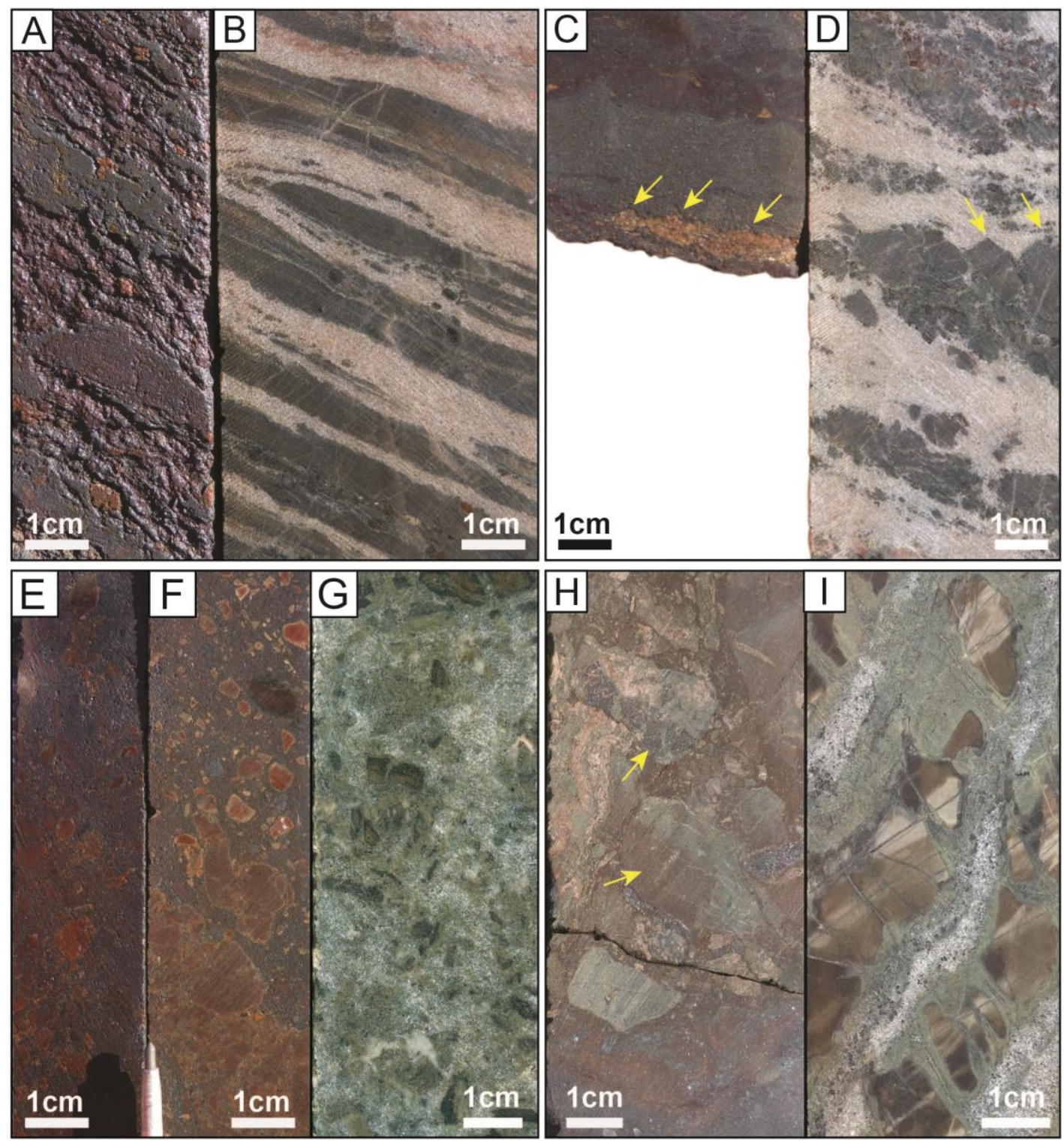

Fig. 6. Textural comparison between hematite breccias from Prominent Hill and calcareous metasedimentary rocks and breccias from the southern Mount Woods domain. (A) Layered hematite breccia, PH04D067, 577 m. (B) Interbedded limestone-argillite from Prominent Hill West, DD08PHW013, 347 m. (C) Hematite breccia showing remnants of boudinaged layers (arrows) in coarser grained hematite matrix, PH05D109, $456.7 \mathrm{~m}$. (D) Limestone-argillite showing boudinage (arrows) from Prominent Hill West, DD08PHW013, 350 m. (E, F) Hematite breccia showing sub-angular to rounded clasts, both PH09D109, $430 \mathrm{~m}$ and $388.4 \mathrm{~m}$, respectively. (G) Calcareous matrix-bearing pelite breccia showing rounded clasts, DD11JDMSE002, 636 m. (H) Hematite breccia with argillaceous clasts partly replaced by hematite (arrows), PH05D109, $494.8 \mathrm{~m}$. (I) Calcareous matrix-supported breccia with boudinaged sub-angular to rounded clasts, DD11JDMSE001 approx. $345 \mathrm{~m}$. 
Hematite breccias south of the HWFZ: The hematite breccias immediately south of the HWFZ are predominantly altered calcareous sedimentary host rocks. These breccias formed by the replacement of calcareous and siliciclastic breccia and rock components. This interpretation is supported by textural comparison between regional, hematite-barren, calcareous (meta-) sedimentary rocks and hematite breccias from Prominent Hill (Fig. 6). Hematite pervasively replaced calcareous and dolomitic lithologies or altered (nearly) the entire rock. The hematite breccias and their least-altered equivalents show layering (Fig. 6A, B), brittle fracturing (Fig. 6C-I), and angular as well as rounded clasts that were probably formed in a sedimentary environment well, before hematite alteration and Cu mineralization (Fig. 6E-I). The replacement commonly resulted in increased porosity (Fig. 6A), and likely enhanced permeability of the hematite breccias, compared to their hematite-barren equivalents (Fig. 6B). The boudinaged and aligned clast fabric remained intact (Fig. 6C, D). Clast types are variable and contain altered host rock components as well as red-dusted granitoid clasts. Breccia clasts appear frayed and are partly or completely replaced by hematite (Fig. 6H, arrows). Additional hydrothermal alteration phases include carbonates (i.e., siderite, ankerite, and dolomite), sericite (likely phengite), chlorite, fluorite, barite, quartz, fluorapatite, REE-minerals (including monazite), uraninite, coffinite, and $\mathrm{Cu}-(\mathrm{Fe})$-sulfides. Chlorite, muscovite, and sericite present in the sedimentary rocks and hematite breccia matrix are not entirely of hydrothermal origin, because they are abundant in calcareoussiliciclastic sedimentary host rocks such as sub-arkose (Fig. 7A, B), in detrital, interstitial muscovitebearing graywacke, and in interbedded, argillaceous-dolostone (Freeman and Tomkinson, 2010). However, chlorite and sericite are also hydrothermal alteration products because feldspars in the host rock and hematite breccia are altered to these minerals.
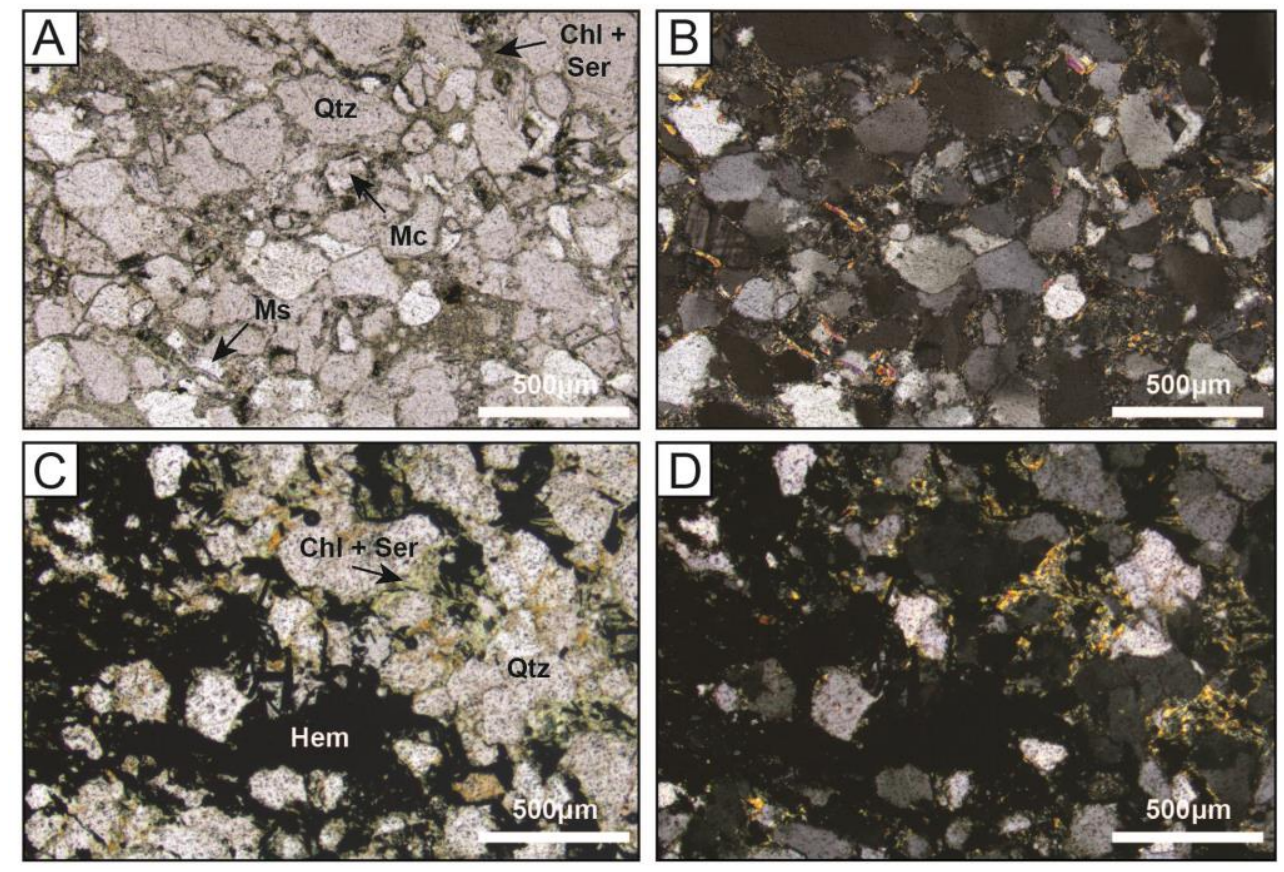

Fig. 7. (A, B) Photomicrographs showing muscovite- and chlorite-cemented quartz grains and feldspars in regional subarkose, (A) polarized light, (B) cross-polarized light; southern Mount Woods domain. (C, D) Hematite replacing finely intergrown sericite and chlorite cement of altered sandstone component in sample from Malu pit, stage 1, 10016 mRL, (C) polarized light, (D) cross-polarized light. Mineral abbreviations: Chl, chlorite; Hem, hematite; Mc, microcline; Qtz, quartz; Ser, sericite.

Two dominant hematite-bearing alteration varieties are present at Prominent Hill. Hematite and quartz replacement (Fig. 8) led to the formation of hematite-quartz breccia, whereas replacement by hematite, chlorite, and sericite (Fig. 9) resulted in hematite-aluminosilicate breccia formation. Together, these two types of hematite breccia represent the Prominent Hill hematite breccia body. 
Careful examination of the drill core has identified not only the two hematite breccia end members, but also the variability of breccia and host rocks affected by varying degrees of hematite-quartz to hematite-chlorite-sericite alteration; transitional varieties were developed in brecciated and unbrecciated host rocks. Significantly, the alteration varieties quantitatively correlate to $\mathrm{Cu}$ and to a lesser extent to Au grades. The footwall volcanic rocks are altered to hematite-quartz to hematitechlorite-sericite-leucoxene-carbonate assemblages and are partly mineralized by $\mathrm{Cu}$.
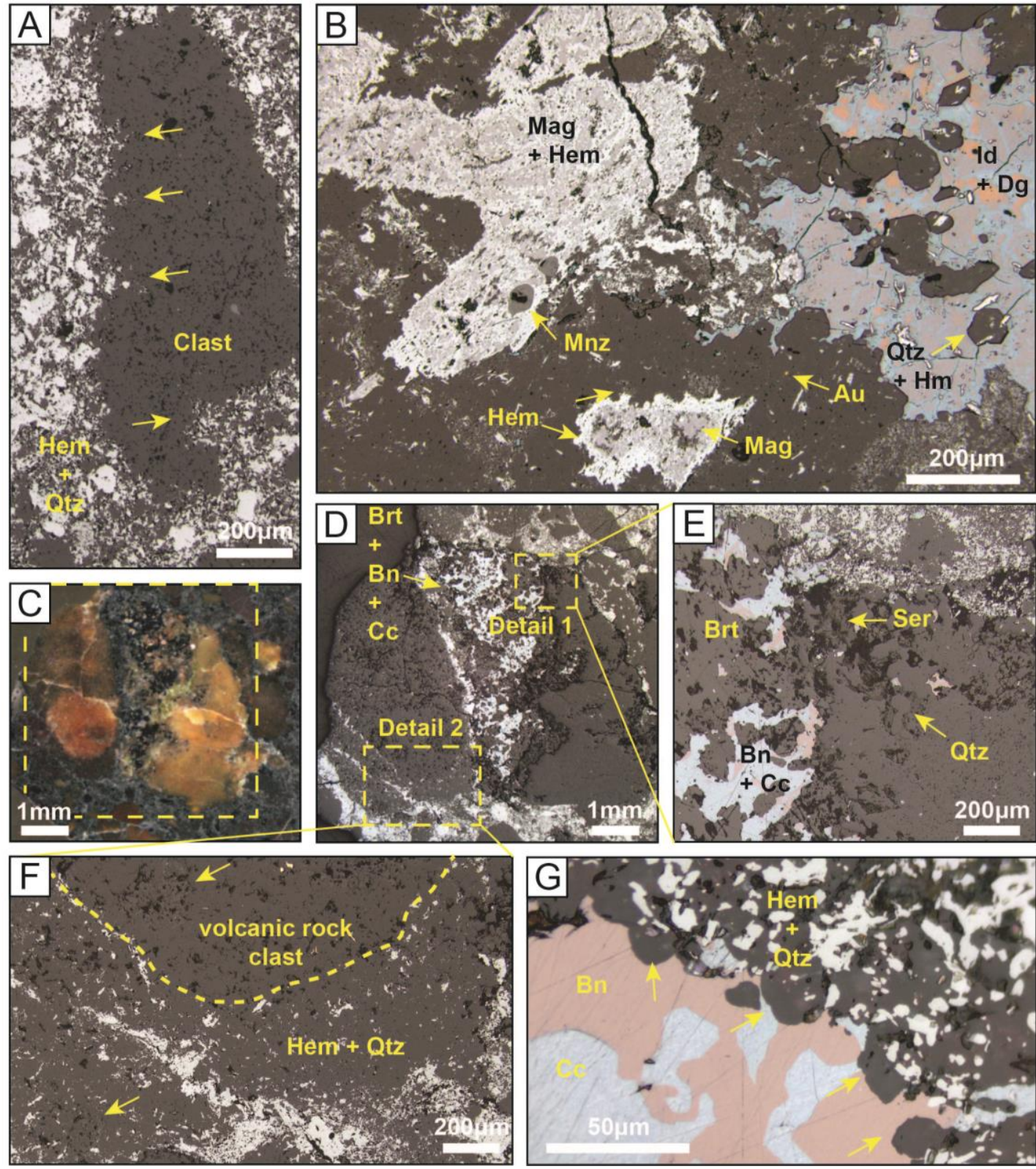

Fig. 8. Photomicrographs of hematite-quartz-altered breccias at Prominent Hill. (A) Hematite-quartz alteration resulted in texture destruction and embayments of clast boundaries (arrows) composed of hematite and quartz; note blurred boundaries, PH05D114, $232.5 \mathrm{~m}$. (B, right) Subhedral and corroded quartz and hematite crystals project into cavity filled with idaite and digenite; (left) magnetite islands surrounded by hematite and monazite; PH05D114, 466.9 m. (C-F) Centimeter-sized breccia clasts showing clast blurring, and color and texture changes; PH05D160, 447.2 m (C) Volcanic clast in normal light and (D) in reflected light. (E) Euhedral quartz forms at hematite-quartz alteration front; quartz is followed paragenetically by sericite, barite, and $\mathrm{Cu}$-(Fe)-sulfides. (F) Hematite-quartz alteration front (dashed line) separates hematite-poor and porous clast center from denser clast rim; arrows mark filled vesicles in precursor volcanic rock. (G) Relationship between subhedral quartz and hematite projecting into cavities (arrows); quartz removal and late infill by bornite and chalcocite; PH05D160, 581.9 m. Mineral abbreviations: Brt, barite; Bn, bornite; Cc, chalcocite; Chl, chlorite; Dg, digenite; Hem, hematite; Id, idaite; Mag, magnetite; Mnz, monazite; Qtz, quartz; Ser, sericite. 

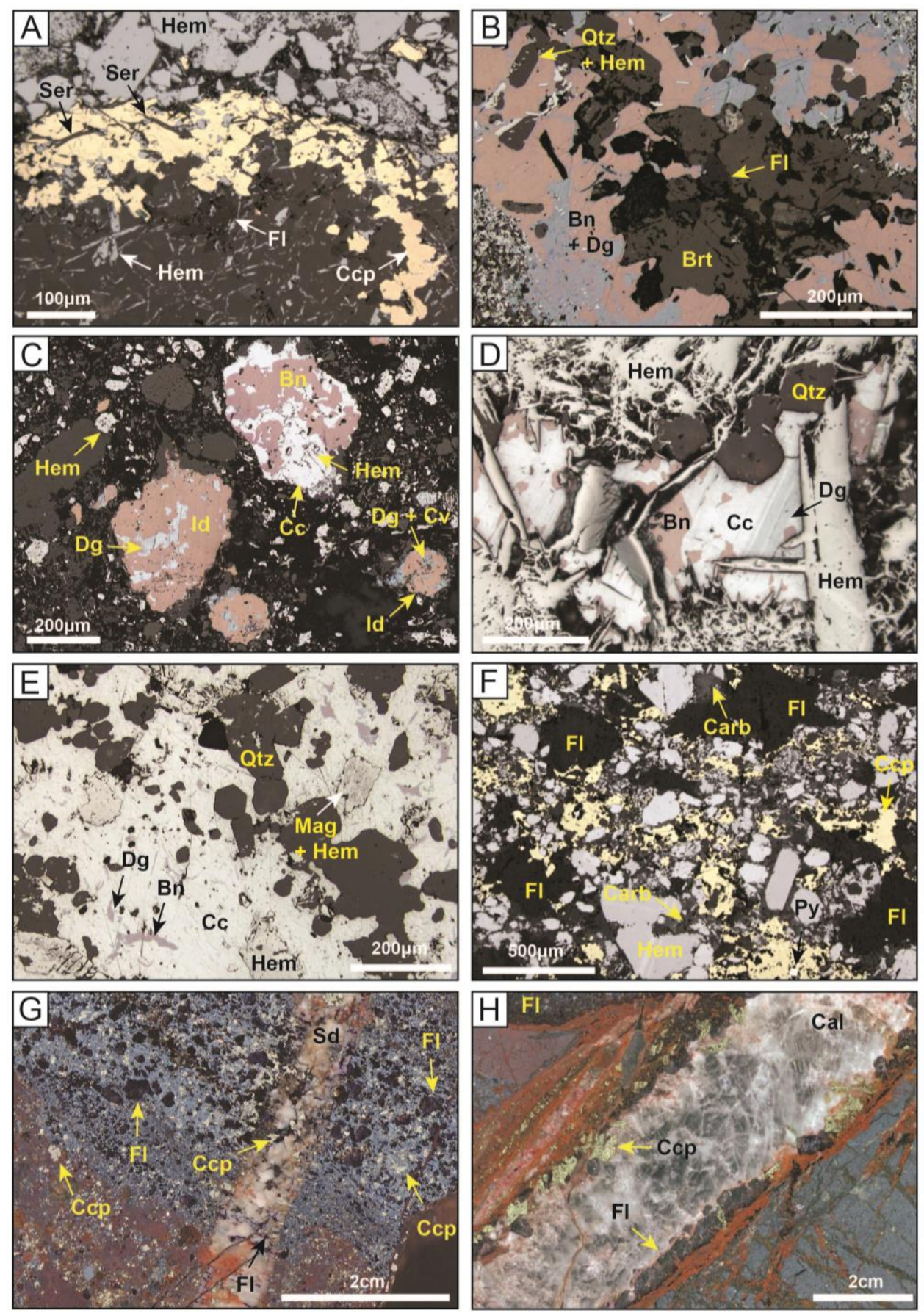

Fig. 9. Hematite-chlorite-sericite \pm carbonate \pm fluorite \pm quartz-altered and mineralized hematite breccias from Prominent Hill. (A) Hematite forms pseudomorphs of plagioclase in volcanic clast; clast rim shows sericite intergrown with chalcopyrite; PH05D114, $407.8 \mathrm{~m}$. (B) Association of $\mathrm{Cu}$-(Fe)-sulfides intergrown with fluorite after formation of euhedral quartz and hematite; PH05D114, $423.1 \mathrm{~m}$. (C) Bornite, chalcocite, covellite, digenite, and idaite are intergrown in variable proportions and assemblages within one sample; PH05D057, 189.3 m. (D) Coarse- to fine-grained and porous breccia matrix contains subhedral quartz and hematite crystals and late infill of chalcocite and bornite (indicated by acute triangular textures); Malu stage 1, $10016 \mathrm{mRL}$. (E) Chalcocite replacing digenite-coated bornite in breccia matrix previously altered to hematite-quartz; PH05D114, 305.9m. (F) Chalcopyrite-fluorite-pyrite-bearing hematite matrix containing fine-grained carbonate within interstices; PH05D169, $367.8 \mathrm{~m}$. (G) Hematite breccia showing patchy fluorite; chalcopyrite is cut by siderite-fluorite-chalcopyrite - pyrite vein, PH09D259, $179.9 \mathrm{~m}$. (H) Hematite-aluminosilicate breccia crosscut by calcite fluorite - chalcopyrite vein; PH05D130, 438.3 m. Mineral abbreviations: Brt, barite; Bn, bornite; Cal, calcite; Cc, chalcocite; Ccp, chalcopyrite; Dg, digenite; Hem, hematite; Fl, fluorite; Id, idaite; Mag, magnetite; Py, pyrite; Qtz, quartz; Ser, sericite. 
Hematite-quartz alteration: In general, the formation of hematite-quartz \pm fluorapatite \pm barite \pm fluorite \pm REE alteration minerals including monazite \pm Au produced a dense intergrowth of finegrained hematite and quartz in altered volcanic rocks. Hematite-quartz alteration in a calcareoussiliciclastic protolith formed cryptocrystalline silica intergrown with hematite, and in cases of intense pervasive alteration, hematitic jasperoid. Most of the Au mineralization is within the margins of the hematite-quartz alteration zone (Belperio et al., 2007) and within the transition to the surrounding hematite-chlorite-sericite-altered rocks (see below). The pervasive alteration style variably replaced unbrecciated host rocks and the breccia body. Within volcanic or sedimentary host rocks, hematitequartz alteration is responsible for substitution of rock components. For example, feldspars (Fig. 4), carbonate (Fig. 6), amphibole, muscovite, sericite, chlorite, were replaced by hematite and/or quartz (Figs. 4, 7 and 8). Destruction of the breccia texture (Fig. 8) is indicated by the presence of frayed and irregularly shaped clasts showing embayments by hematite and quartz into the clasts (Fig. 8A, arrows). In addition to replacement of carbonate and siliceous rock components, other characteristics of the hematite-quartz alteration are (1) euhedral to subhedral quartz and hematite (Fig. 8B, E) in which crystals project into small breccia cavities (Fig. 8B); (2) dull color changes in (semi-) altered clasts (Fig. 8C-D); and (3) reduction of porosity (Fig. 8F). Generally, hematite-quartz-altered rocks and breccias display only weak $\mathrm{Cu}$ mineralization. Where $\mathrm{Cu}-(\mathrm{Fe})$-sulfides are found in the hematitequartz-altered breccia matrix, the mineralization commonly took place after local quartz leaching, as indicated by corroded quartz crystals (Fig. 8B, G).

Hematite alteration and mineralization: Hematite-chlorite-sericite \pm siderite \pm ankerite \pm kaolinite \pm barite \pm fluorite \pm fluorapatite \pm REE minerals (including monazite) $\pm \mathrm{Cu}$-(Fe)-sulfide alteration is associated with $\mathrm{Cu}$-mineralization in the hematite-aluminosilicate breccia matrix (Fig. 9). The hematite-aluminosilicate breccia is generally porous and softer than the hematite-quartz breccia. Matrix textures vary between finely layered, to massive, and fine-grained to millimeter-scale crystalline hematite aggregates, meshes or disk-shaped networks. Dark gray to black colors are typical. In contrast, the earthy hematite matrix is fine-grained, granular, and red to brown.

$\mathrm{Cu}-(\mathrm{Fe})$-sulfide minerals including chalcocite, digenite, bornite, idaite, and chalcopyrite are abundant in the breccia matrix (Fig. 9A-G). Covellite is volumetrically minor. These Cu sulfides are intergrown with fine- to coarse grained hematite, sericite (Fig. 9A), barite, fluorite (Fig. 9B), carbonates (Fig. 9F), and locally quartz (Fig. 9E), or replace euhedral to anhedral pyrite (Belperio et al., 2007; Schlegel, 2010). Hematite forms pseudomorphs after feldspars in volcanic clasts (Fig. 9A). Vermicular and complexly intergrown $\mathrm{Cu}-(\mathrm{Fe})$-sulfide assemblages occur in different samples throughout the deposit (Fig. 9B, C). Triangular acute mineral textures show that the $\mathrm{Cu}-(\mathrm{Fe})$-sulfides formed not only by replacement of pyrite but by infill of previously hematite (-quartz)-altered breccia (Fig. 9D-E). Locally, intense hematite-fluorite-barite alteration is spatially associated with chalcopyrite-pyrite mineralization (Fig. 9F), occurring in patches adjacent to the hematite-only breccia matrix. Discrete accumulations of fluorite and/or barite are intergrown with hematite and $\mathrm{Cu}$-(Fe)-sulfides (Fig. 9G). These gangue minerals contain abundant Ca-Na-dominant fluid inclusion assemblages (Schlegel et al., 2012). Carbonates present in the hematite-fluorite-barite alteration assemblage include calcite and siderite, which are generally fine-grained and fill matrix interstices (Fig. 9F), or constitute major components of veins cutting the hematite breccia (Fig. 9G, H). Significantly, high-grade $\mathrm{Cu}$ mineralization is typically confined to areas of the breccia matrix that contain fine- to coarse-grained crystalline hematite and visible sericite.

$\mathrm{Cu}$-(Fe)-sulfides also replace breccia clasts and massive (unbrecciated) host rock (Fig. 10). The replacements did not homogeneously affect the entire breccia or rock. For example, centimeter-sized clasts are partly or completely replaced by chalcocite (Fig. 10A) or chalcopyrite and fluorite (Fig. 10B). This process resulted in clast rounding and pseudo-brecciation (Fig. 10C-G). High Cu grades also occur in short intervals as chalcocite and bornite-rich replacements of unbrecciated host rock. Where replacement mineralization is observed in hematite-quartz-altered breccia, $\mathrm{Cu}$-(Fe)-sulfides are intergrown with barite and together replace breccia clasts; the matrix, in contrast, remains poor in $\mathrm{Cu}$-sulfides and barite (Fig. 10D-F). The lateral extent of clast replacement is to some extent controlled 
by original textures and clast size. Smaller clasts commonly show complete replacement whereas larger clasts are partially corroded (Fig. 10G).
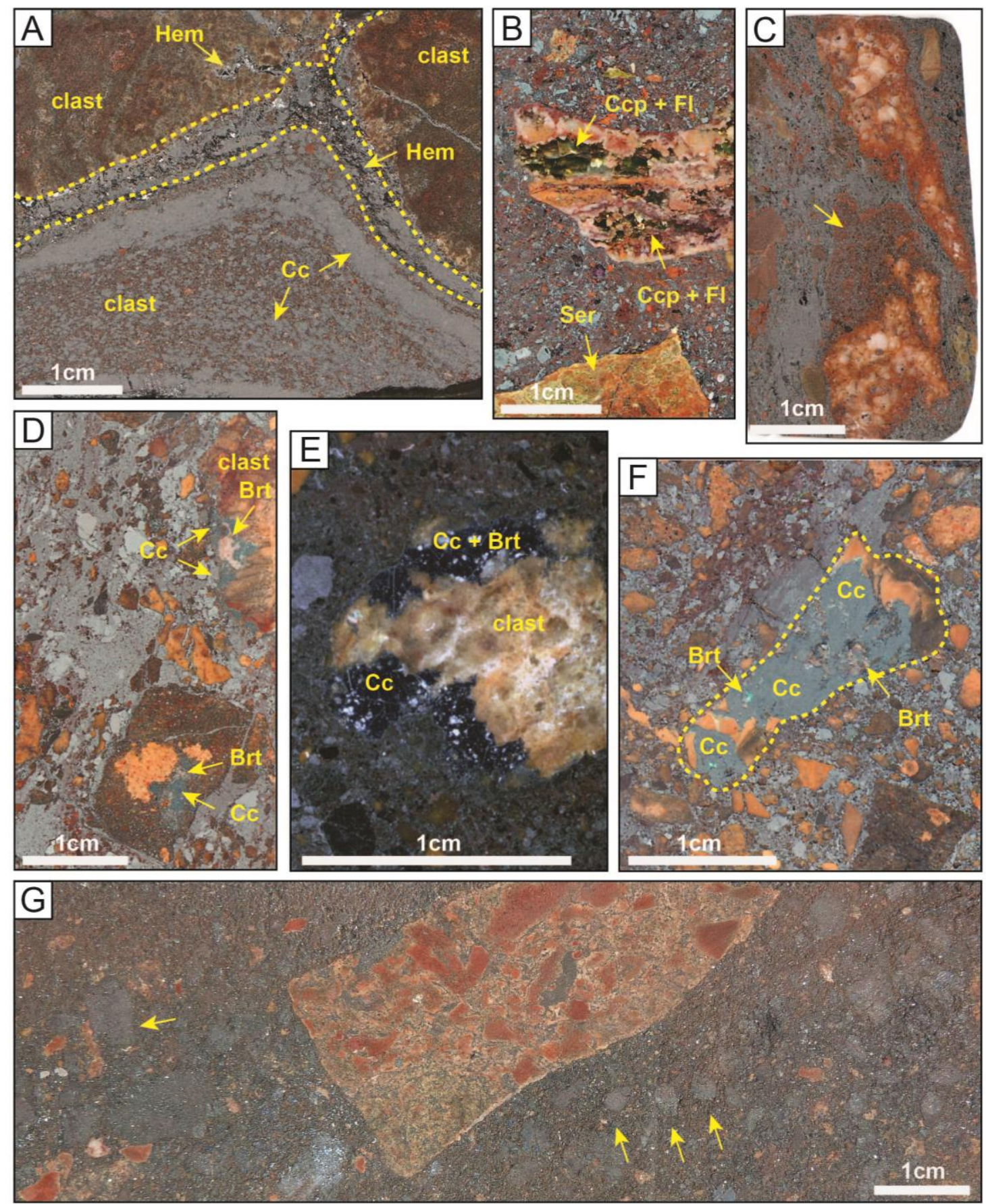

Fig. 10. Hematite and $\mathrm{Cu}-(\mathrm{Fe})$-sulfide replacements of breccia clasts at Prominent Hill. (A) Hand specimen with chalcocite replacing a weakly hematite-altered sandstone clast; clast boundaries are indicated by dashed lines; matrix consists of $\mathrm{Cu}$ sulfide-poor specularite; Malu pit. (B) Chalcopyrite and fluorite partly replace sericite-altered sedimentary rock clast; PH04D057, 186.1 m. (C) Crystalline hematite corrodes hematite-dusted clast (arrow); PH05D130, 408.6 m. (D) Hematitequartz-altered breccia showing clasts partly replaced by chalcocite and barite; note color change due to hematite-quartz alteration (lower center) similar to that in Fig. 8C; PH06D224, $366.1 \mathrm{~m}$. (E) Blurred clast boundary partly replaced by chalcocite and barite; PH05D114, $436.6 \mathrm{~m}$. (F) Chalcocite and barite replacement of breccia clast; dashed line marks minimum clast extent before replacement; PH06D204, $359.5 \mathrm{~m}$. (G) Hand specimen showing diffuse hematite \pm fine-grained chalcocite replacement of clasts including destruction of original texture; note that smaller clasts are completely replaced by hematite (arrows); PH12GC541, approx. 24 m. Mineral abbreviations: Brt, barite; Cc, chalcocite; Ccp, chalcopyrite, Fl, fluorite. 
Variable $\mathrm{Cu}-(\mathrm{Fe})$-sulfide assemblages, with or without pyrite, occur throughout the footwall (Fig. 11) and locally display complex textures. In previously hematite-quartz-altered breccia, chalcocite replaces digenite-coated bornite (Fig. 9E). Fe-depleted rims of chalcocite and digenite surrounding bornite relicts were observed in weakly mineralized, hematite-quartz-altered rocks and in transition zones at depth towards hematite-chlorite-sericite-altered breccia (e.g., Figs. 9E and 11C). However, no conspicuous mine-scale zonation of $\mathrm{Cu}$ - $(\mathrm{Fe})$-sulfide minerals or dependence of mineralogy on depth below the paleo-erosion surface is observed (Fig. 11). The paragenetic sequence of mineral precipitation is therefore derived mainly from smaller-scale petrographic relationships (Fig. 12).

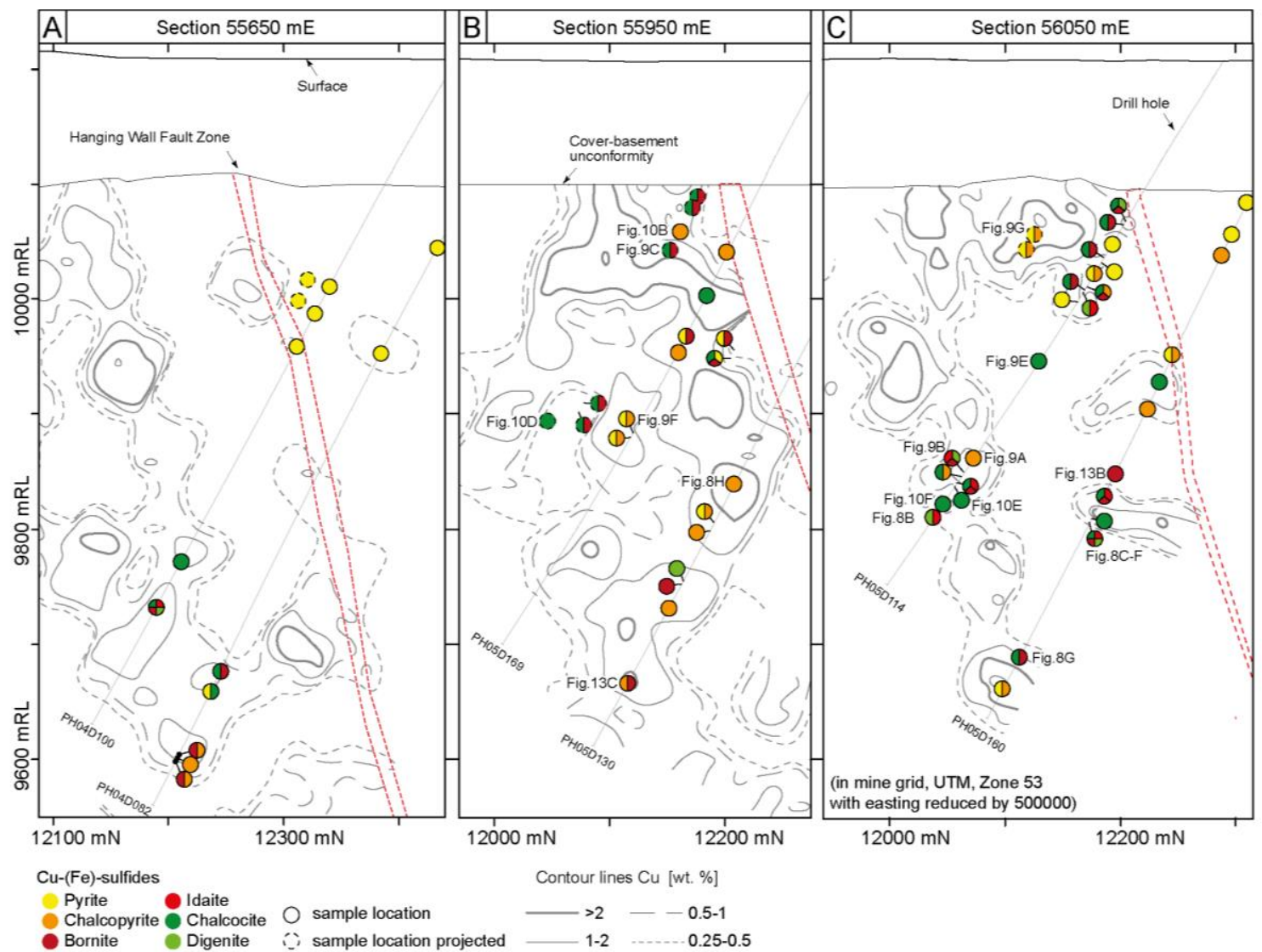

Fig. 11. Cross sections (A) $55650 \mathrm{mE}$, (B) $55950 \mathrm{mE}$, and (C) $56050 \mathrm{mE}$ through the Prominent Hill deposit showing locations and types of $\mathrm{Cu}-(\mathrm{Fe})$-sulfides, and locations of pyrite-bearing petrographic samples on top of the $\mathrm{Cu}$ grade contours.

Veins: An irregular set of veins, with thickness up to $10 \mathrm{~cm}$, cuts the footwall lithologies (Fig. 9G, $\mathrm{H})$. The vein types include: (a) specular hematite-Cu-(Fe)-sulfides \pm quartz, (b) calcite-barite-pyrite \pm fluorite \pm chalcopyrite \pm bornite \pm chalcocite, (c) siderite-quartz-fluorite-barite-chalcopyrite \pm calcite, and (d) barite-bornite-chalcocite \pm hematite. Siderite \pm quartz \pm fluorite \pm chalcopyrite veins, without barite and calcite, are abundant locally. Hematite is the predominant mineral in all vein types. However, the same mineral assemblages also fill porous breccia and centimeter-sized cavities in the breccias. Paragenetically late fluorite-pyrite-pyrrhotite-magnetite-bearing veins are rare, occurring locally in the footwall of the HWFZ (Fig. 12).

Relative timing of mineralization: As reported by Freeman and Tomkinson (2010), economic $\mathrm{Cu}$ mineralization with abundant $\mathrm{Cu}$ sulfides occurred relatively late in the mineral paragenesis (Fig. 12). Hematite-dominant alteration formed in pulses, as indicated by the presence of multiple generations of hematite overgrowths and encrustations. One or more generations of pyrite ( \pm chalcopyrite) likely predate much of the $\mathrm{Au}$ mineralization, which in turn was temporally associated with hematitequartz alteration and late barite-bearing veins. The hematite-aluminosilicate breccias typically 
contain bornite, chalcocite, digenite, and idaite accompanied by barite and/or chalcopyrite as replacements of pyrite (Belperio et al., 2007; Schlegel, 2010). Mineralization occurred in cycles (Fig. 12), as recorded by mutually overprinting generations of $\mathrm{Cu}$-(Fe)-sulfide assemblages (Fig. 9) and by successive veins of diverse mineralogy (Fig. 12). Oriented drill cores (relative to horizontal) contain geopetal structures (Fig. 13) showing that Cu-rich sulfide mineralization formed when the brecciated host strata (Fig. 6) had a steeply dipping attitude, close to the geometry found today. Thus, economic $\mathrm{Cu}$ mineralization occurred after the extrusion of the inferred lower GRV (Belperio et al., 2007) because these strata were tilted steeply prior to alteration and mineralization in the deposit area.

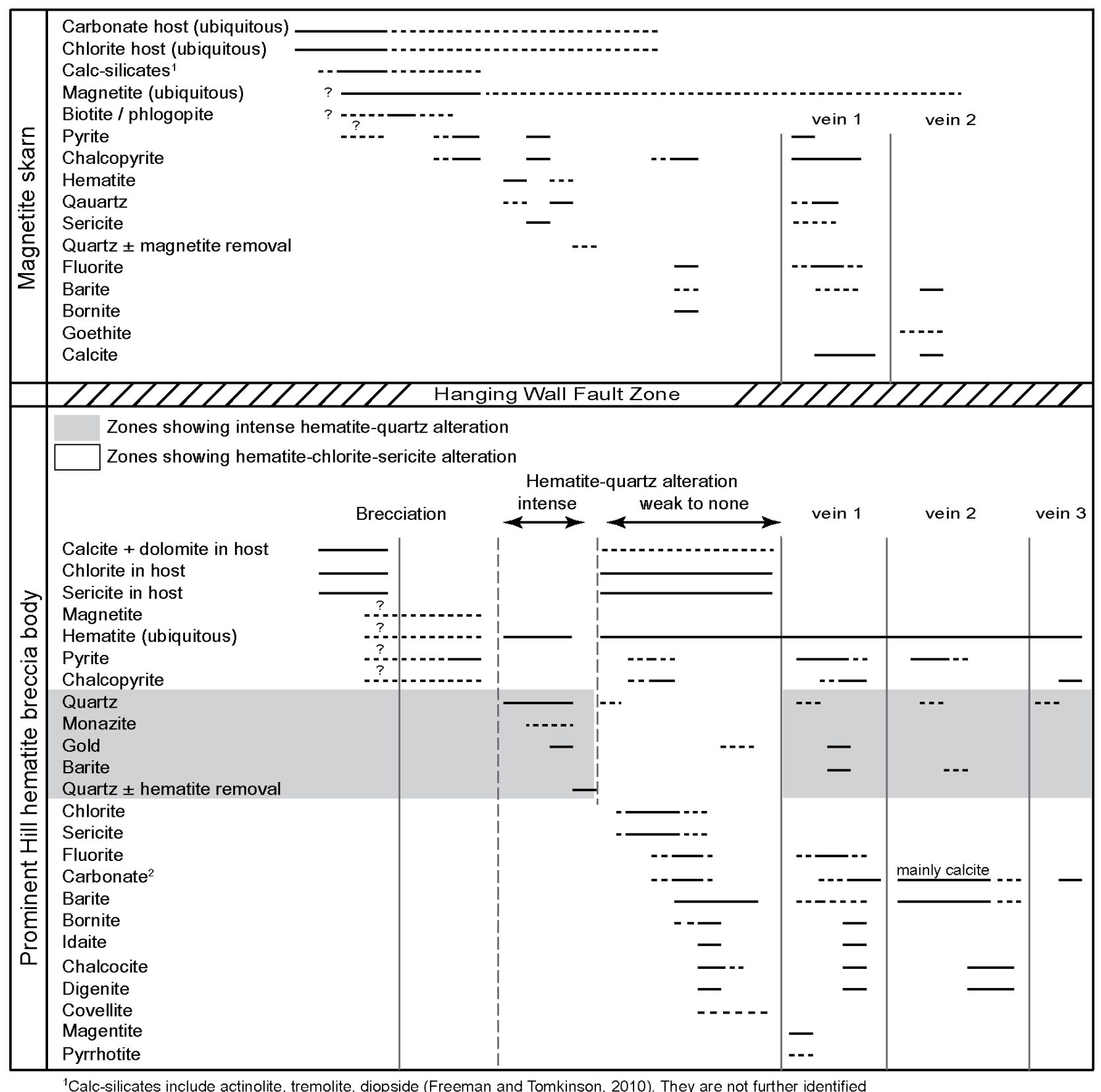

${ }^{1}$ Calc-silicates include actinolite, tremolite, diopside (Freeman and Tomkinson, 2010). They are not further identified

${ }^{2}$ Siderite, ankerite, dolomite, calcite. They are not further identified

Fig. 12. Simplified mineral paragenesis of the Prominent Hill magnetite skarn (top) and hematite breccia body (bottom) with the Hanging Wall Fault Zone separating the hanging wall (subeconomic) from the footwall (economic). 


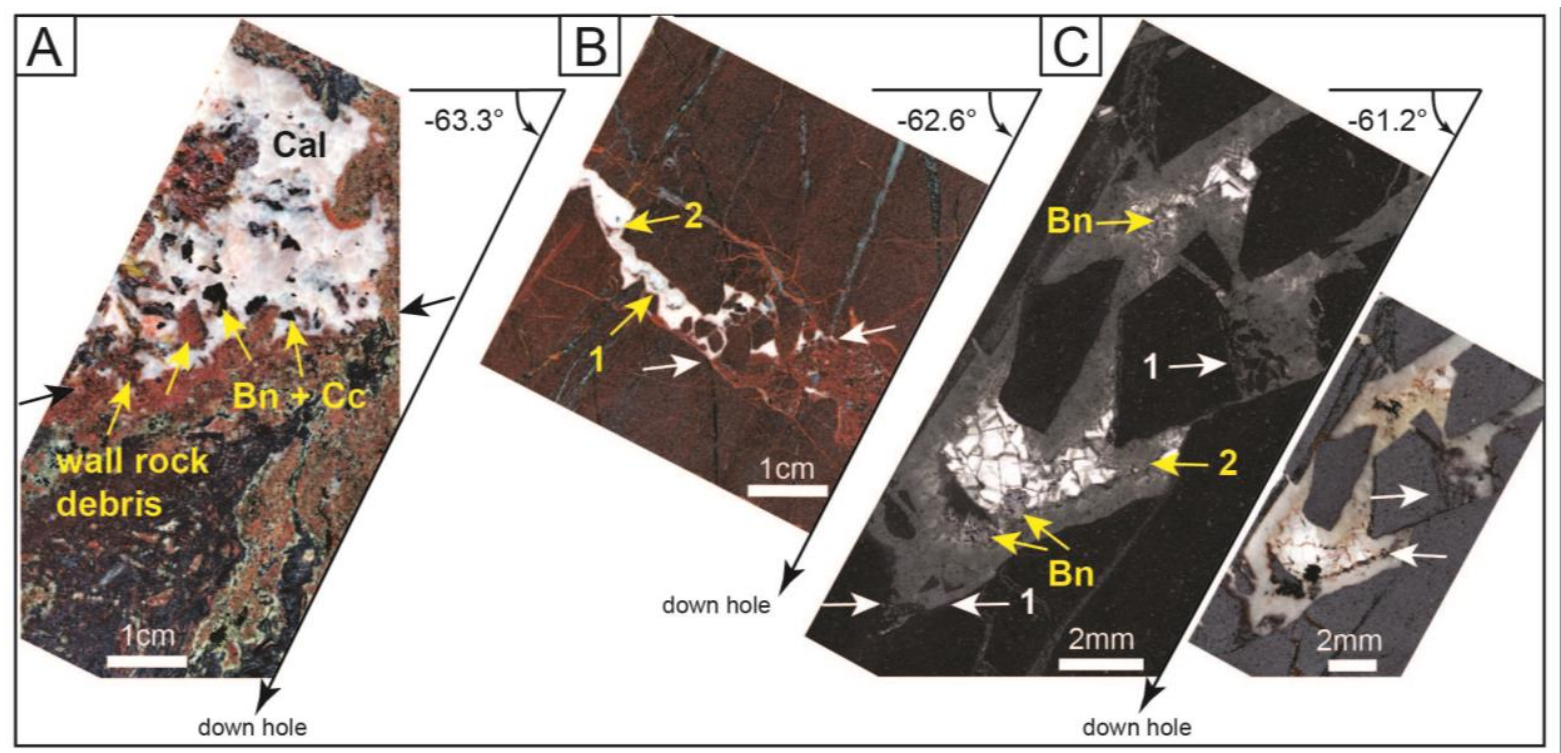

Fig. 13. Geopetal structures in oriented drill core from Prominent Hill indicate that Cu-rich sulfide mineralization occurred after tilting of the host rocks to a steep orientation. (A) Hematite-sericite \pm chlorite-altered graywacke showing cavity with sericite-altered wall rock debris and $\mathrm{Cu}$-sulfides at bottom (yellow arrows), and late calcite infill; PH07D313, 569.4 m. (B) Hematite-quartz-altered sandstone showing cavity partly filled with altered sandstone debris followed by deposition of two calcite generations separated by fine-grained hematite and Cu-sulfide precipitations 1 and 2 (yellow arrows); PH05D160, $402.1 \mathrm{~m}$. (C) Combined transmitted and reflected light image (left) and normal photo (right) of hematite-quartz-altered sandstone with cavity filled by wall rock debris of generation 1 (white arrows) and calcite; sandstone clasts are rimmed by calcite (gray) followed by bornite, hematite, (yellow arrow), and later infill of barite (transparent); PH05D130, 615.4 m. Mineral abbreviations: Bn, bornite; Cal, calcite; Cc, chalcocite.

\section{Geochemistry of the Prominent Hill Deposit}

Intense hematite- and magnetite-dominant alteration nearly completely changed the textures and compositions of original igneous and sedimentary rocks (Figs. 2-10). Hence, the identification of elemental tracers, ideally fingerprinting precursor lithologies within the hematite breccia body, provides insights as to whether the $\mathrm{Cu}$ distribution can be correlated with the distribution of alteration and/or the spatial extent of host lithologies.

In order to establish a chemical lithology model for the Prominent Hill deposit, alterationconservative elements need to be identified. In principle, ratios of such elements will not be affected by brecciation and hydrothermal mass gains or losses, but will retain the value of the protoliths. Among the commonly used candidates for limited mobility, only $\mathrm{Al}, \mathrm{Ti}$, and $\mathrm{Si}$ were regularly assayed in sufficiently small drill core intervals, whereas $\mathrm{Zr}, \mathrm{Hf}$, or $\mathrm{Nb}$ were determined only in a small subset of exploration samples and our own multielement analyses.

\subsection{Sampling, analytical methods, drill holes, and assay database}

Sample descriptions (Table 1), analytical methods, and information on the drill-hole and assay database, as well as results of the alteration mass-balance calculations (Table 2) are provided in the Appendix. Detailed results of the major- and trace element analyses are in the online electronic supplement.

\subsection{Mass transfer during alteration of host rocks}

Major and trace-element concentrations were used to determine the least mobile elements and calculate alteration mass balance for two variably altered but coherent volcanic rock sequences from 
Table 1. Sample description for rocks used in this study.

\begin{tabular}{|c|c|c|c|c|}
\hline Location & $\begin{array}{l}\text { Sample- } \\
\text { No. }\end{array}$ & Hole / Pit & $\begin{array}{l}\text { Depth }[\mathrm{m}] / \\
\text { Location }\end{array}$ & Sample description \\
\hline \multicolumn{5}{|c|}{ Joes Dam SE } \\
\hline & PH516 & DD11JDMSE001 & 278.7 & $\begin{array}{l}\text { Magnetite - pyrite alteration affecting unbrecciated interbedded } \\
\text { limestone-pelite, carbonate replaced by magnetite and pyrite }\end{array}$ \\
\hline & PH517 & DD11JDMSE003 & 124.9 & Argillite \\
\hline & PH518 & & 115.7 & $\begin{array}{l}\text { Magnetite - pyrite rock showing dense magnetite - pyrite clasts from } \\
\text { earlier alteration cycle, magnetite alteration pre and after brecciation }\end{array}$ \\
\hline & PH519 & & 112.4 & $\begin{array}{l}\text { Magnetite - pyrite clast in calcareous breccia matrix, magnetite alteration } \\
\text { pre brecciation and carbonated matrix formation }\end{array}$ \\
\hline & PH551 & DD11JDMSE001 & 391.7 & Interbedded limestone-argillite \\
\hline \multicolumn{5}{|c|}{ Prominent Hill } \\
\hline & PH131 & Pit stage 1 & unkn & Greenish colored hematite breccia showing reworked breccia clasts \\
\hline & PH143 & PH05D130 & 615.4 & $\begin{array}{l}\text { Geopetal in hematite - quartz altered sandstone; cavity filled with altered } \\
\text { wall rock debris, calcite, bornite and barite }\end{array}$ \\
\hline & PH165 & & 408.8 & Pseudo clast in hematite breccia; partly by hematite replaced clast \\
\hline & PH19 & PH07D313 & 569.4 & $\begin{array}{l}\text { Geopetal in oriented drill core, cavity infill consists of wall rock debris } \\
\text { incl. } \mathrm{Cu} \text {-sulfides and barren calcite }\end{array}$ \\
\hline & $\mathrm{PH} 222$ & PH05D169 & 367.8 & $\begin{array}{l}\text { Chalcopyrite - fluorite - pyrite in hematite breccia, patchy fluorite } \\
\text { intergrown with chalcopyrite seems to overprint earlier hematite matrix }\end{array}$ \\
\hline & PH285 & PH05D160 & 403.7 & Hematite - quartz altered sandstone \\
\hline & PH306 & PH05D114 & 466.9 & $\begin{array}{l}\text { Large bornite and chalcocite in highly altered fine grained hematite- } \\
\text { quartz breccia, volcanic rock or sandstone }\end{array}$ \\
\hline & PH310 & & 436.6 & Chalcocite and bornite replaces hematite-quartz breccia clast \\
\hline & PH315 & & 423.1 & Bornite - chalcocite - fluorite and barite bearing hematite breccia matrix \\
\hline & PH316 & & 407.8 & Chalcopyrite in hematite-quartz breccia matrix \\
\hline & PH320 & & 283.9 & $\begin{array}{l}\text { Hematite - quartz altered sandstone showing cavity with red barite } \\
\text { and chalcopyrite }\end{array}$ \\
\hline & PH326 & & 232.5 & $\begin{array}{l}\text { Dense hematite-quartz breccia showing red barite and } \\
\text { chalcocite-bearing vein }\end{array}$ \\
\hline & PH462 & PH09D259 & 179.9 & $\begin{array}{l}\text { Fluorite ( } 40-50 \%) \text { - chalcopyrite-rich hematite breccia cross cut by } \\
\text { siderite - fluorite } \pm \text { quartz and chalcopyrite vein }\end{array}$ \\
\hline & PH505 & PH05D057 & 186.1 & $\begin{array}{l}\text { Cu-poor hematite breccia matrix with fluorite, chalcopyrite and } \\
\text { barite replacing } \mathrm{cm} \text {-scaled clast }\end{array}$ \\
\hline & PH507 & PH06D224 & 359.5 & Chalcocite and barite semi-replaced clast in dense hematite-quartz breccia \\
\hline & PH511 & & 366.1 & Chalcocite and barite semi-replaced clast in dense hematite-quartz breccia \\
\hline & PH82 & PH05D130 & 438.2 & Calcite - fluorite - chalcopyrite vein cutting hematite breccia \\
\hline & PH09 & Pit stage 1 & $10016 \mathrm{mRl}$ & $\begin{array}{l}\text { Hematite breccia, high grade } \mathrm{Cu} \text { ore showing bornite and } \\
\text { chalcocite in breccia matrix }\end{array}$ \\
\hline \multicolumn{5}{|l|}{ Triton } \\
\hline & PH640 & DD09TRI007 & 526.5 & fine-grained massive basalt \\
\hline & PH621 & & 291.2 & Fine grained basaltic andesite \\
\hline & PH645 & DD09TRI006 & 132.9 & Andesite \\
\hline & PH647 & & 141.2 & Hematite altered andesite \\
\hline & PH651 & & 203.7 & Hematite - chlorite altered andesite \\
\hline & PH653 & & 204.8 & Hematite - chlorite - sericite altered andesite \\
\hline & PH654 & & 209.2 & Hematite - chlorite - sericite altered andesite \\
\hline & PH655 & & 212.4 & Hematite - chlorite - sericite to hematite - quartz altered andesite \\
\hline & PH656 & & 214.2 & Hematite - chlorite - sericite to hematite - quartz altered andesite \\
\hline & PH658 & & 280.0 & Magnetite - pyrite \pm quartz \pm apatite altered fine grained andesite \\
\hline & PH659 & & 284.8 & Magnetite - pyrite \pm quartz \pm apatite altered fine grained andesite \\
\hline & PH660 & & 287.0 & Magnetite - pyrite - quartz - apatite altered fine grained andesite \\
\hline & PH661 & & 285.4 & Magnetite - pyrite - quartz - apatite altered fine grained andesite \\
\hline
\end{tabular}


Table 1. (continued)

\begin{tabular}{|c|c|c|c|c|}
\hline Location & $\begin{array}{l}\text { Sample- } \\
\text { Nr. }\end{array}$ & Hole / Pit & $\begin{array}{l}\text { Depth }[\mathrm{m}] / \\
\text { Location }\end{array}$ & Sample description \\
\hline \multicolumn{5}{|l|}{ Triton } \\
\hline & PH662 & DD09TRI006 & 289.6 & Magnetite - pyrite - quartz - apatite altered fine grained andesite \\
\hline & PH678 & & 548.5 & Fine grained basaltic andesite \\
\hline & PH681 & & 618.7 & Fine grained basaltic andesite \\
\hline & XPH656 & & 213.2 & Hematite - quartz altered andesite, late calcite infill in pores \\
\hline \multicolumn{5}{|c|}{ Southern Mount Woods Domain } \\
\hline & PH513 & $\begin{array}{l}\text { Stratigraphic } \\
\text { drill hole }\end{array}$ & 157.9 & Interbedded limestone (60)-argillite (40) breccia \\
\hline & PH534 & & 551.8 & Laminated, impure limestone \\
\hline & PH559 & & 472.9 & Graywacke \\
\hline & PH560 & & $\sim 252$ & Sandstone (Sub-arkose) \\
\hline & PH562 & & 209.7 & Interbedded limestone(30)-argillite(70) breccia \\
\hline & PH684 & & 323.1 & Calcareous matrix-bearing argillite breccia \\
\hline
\end{tabular}

the Triton prospect (Fig. 1C). Short and closely-spaced drill core intervals of a feldspar-phyric andesite showing different stages of hematite-chlorite-sericite to hematite-quartz alteration (Fig. 3) were selected because these intervals resemble the main hematite alteration styles exposed within the mine. In addition, a magnetite-pyrite-quartz-fluorapatite alteration sequence that replaces finegrained andesite, with $\mathrm{Fe}_{2} \mathrm{O}_{3}$ concentrations up to 62 wt \%, was used to evaluate extreme iron enrichment. The volcanic rocks are plausibly assumed to have been homogeneous, but the sedimentary rocks can be locally heterogeneous. As an approximation, two fine-grained hematitequartz-altered sandstones from Prominent Hill were compared chemically to a muscovite-chloritecemented sub-arkose from the regional sedimentary host sequence (Fig. 7A-B).

Selection of least-mobile elements and alteration mass-balance calculations: Mass-balance equations of Gresens (1967) and their depiction in isocon plots (Grant, 1986, 2005; Lopez-Moro, 2012) were used to quantify the effects of hydrothermal processes. Normalization of each element, such that the squared sum of concentrations of altered and least altered rocks equals 1, makes the identification of conservative elements less biased (Fig. 14A-B; Humphris et al., 1998), by avoiding the arbitrary scaling used in isocon diagrams (Mukherjee and Gupta, 2008). Elements that display similar chemical behavior remain in clusters during progressive alteration, and define a fan with the point of origin in normalized $\mathrm{C}_{0}$ (protolith)- $\mathrm{C}_{\mathrm{a}}$ (altered) diagrams (Fig. 14A-B). Gains and losses were calculated from averages of slope values (Lopez-Moro, 2012) for elements that plot outside the fan. Figure 14A shows the results for intense hematite-chlorite-sericite alteration (Fig. 3C) with Si, P, U, $\mathrm{Hf}, \mathrm{Al}, \mathrm{Ti}, \mathrm{Zr}, \mathrm{V}, \mathrm{La}, \mathrm{Nb}$, and $\mathrm{Ce}$ all clustering on the unit circle. This alteration involves major gains in $\mathrm{Fe}, \mathrm{K}, \mathrm{Ba}, \mathrm{Mo}, \mathrm{Pb}$, and $\mathrm{Cr}$ and losses in $\mathrm{Mg}, \mathrm{Mn}, \mathrm{Ca}, \mathrm{Cu}$, and $\mathrm{Sr}$, for example. During hematite-quartz alteration (Fig. 14B; cf. Fig. 3D-F), several elements including Al deviate from the conservative element cluster as defined by Ti and Zr. Partial mobility of most or all elements is indicated during intense hematite-quartz alteration (Fig. 14B); mass changes in sample XPH656 (Fig. 3F) were quantified relative to $\mathrm{Zr}$, even though this element was probably slightly mobile. The magnetitepyrite \pm chalcopyrite \pm quartz alteration sequence was quantified assuming $\mathrm{Ti}$ as the least-mobile element. Despite these ambiguities, the results (Fig. 14C, D; Table 2) show that Ti, Al, Zr, and Si were only weakly mobile during hematite-chlorite-sericite to weak hematite-quartz alteration (Fig. 14C). However, samples showing intense hematite-quartz and magnetite-pyrite-quartz-apatite replacement resulted in partial to complete loss of $\mathrm{Mg}, \mathrm{Na}, \mathrm{K}$, and $\mathrm{Al}$ and major gains in $\mathrm{Fe}$, $\mathrm{Si}$, and $\mathrm{P}$ (Fig. 14C-D). 
Table 2. Results of the simple alteration mass-balance calculation.

\begin{tabular}{|c|c|c|c|c|c|c|c|}
\hline \multirow[t]{2}{*}{ Sample } & \multirow{2}{*}{$\begin{array}{l}\text { PH645 } \\
\text { "Least } \\
\text { altered" }\end{array}$} & \multicolumn{3}{|c|}{ PH651 } & \multicolumn{3}{|c|}{ PH653 } \\
\hline & & Altered & $\begin{array}{l}\text { Gain/Loss } \\
\text { relative to } \mathrm{C}_{\mathrm{i}}{ }^{0}\end{array}$ & $\begin{array}{l}\text { Gain/Loss in } \\
\text { wt. \% or ppm }\end{array}$ & Altered & $\begin{array}{l}\text { Gain/Loss } \\
\text { relative to } \mathrm{C}_{\mathrm{i}}{ }^{0}\end{array}$ & $\begin{array}{l}\text { Gain/Loss in } \\
\text { wt. \% or ppm }\end{array}$ \\
\hline & $\mathrm{C}_{\mathrm{i}}{ }^{0}$ & $\mathrm{C}_{\mathrm{i}}$ & $\Delta \mathrm{C}_{\mathrm{i}} / \mathrm{C}_{\mathrm{i}}{ }^{0}$ & $\Delta \mathrm{C}_{\mathrm{i}}$ & $\mathrm{C}_{\mathrm{i}}$ & $\Delta \mathrm{C}_{\mathrm{i}} / \mathrm{C}_{\mathrm{i}}{ }^{0}$ & $\Delta \mathrm{C}_{\mathrm{i}}$ \\
\hline $\mathrm{SiO}_{2}$ (wt. \%) & 59.71 & 58.68 & 0 & $\mathbf{0}$ & 57.53 & 0 & 0 \\
\hline $\mathrm{TiO}_{2}$ & 1.12 & 1.11 & o & 0 & 1.11 & 0 & 0 \\
\hline $\mathrm{Al}_{2} \mathrm{O}_{3}$ & 15.88 & 15.56 & $\mathbf{0}$ & $\mathbf{0}$ & 15.42 & $\mathbf{0}$ & $\mathbf{0}$ \\
\hline $\mathrm{Fe}_{2} \mathrm{O}_{3}$ & 8.65 & 8.82 & 0.05 & 0.44 & 9.27 & 0.11 & 0.92 \\
\hline $\mathrm{MnO}$ & 1.06 & 1.08 & 0.05 & 0.06 & 1.11 & 0.08 & 0.09 \\
\hline $\mathrm{MgO}$ & 1.83 & 2.43 & 0.37 & 0.68 & 2.29 & 0.30 & 0.54 \\
\hline $\mathrm{CaO}$ & 1.29 & 1.60 & 0.28 & 0.36 & 1.90 & 0.52 & 0.67 \\
\hline $\mathrm{Na}_{2} \mathrm{O}$ & 4.67 & 5.02 & 0.11 & 0.51 & 4.75 & 0.05 & 0.23 \\
\hline $\mathrm{K}_{2} \mathrm{O}$ & 2.83 & 2.27 & -0.17 & -0.49 & 2.68 & -0.02 & -0.05 \\
\hline $\mathrm{P}_{2} \mathrm{O}_{5}$ & 0.42 & 0.42 & $\mathbf{0}$ & $\mathbf{0}$ & 0.41 & $\mathbf{0}$ & $\mathbf{0}$ \\
\hline Sc (ppm) & 10.9 & 10.3 & 0.0 & -0.3 & 11.0 & 0.0 & 0.5 \\
\hline V & 78.0 & 73.8 & 0 & $\mathbf{0}$ & 74.4 & $\mathbf{0}$ & $\mathbf{0}$ \\
\hline $\mathrm{Cr}$ & 8.9 & 16.8 & 0.9 & 8.4 & 14.2 & 0.7 & 5.8 \\
\hline Co & 35.8 & 28.0 & -0.2 & -6.9 & 25.4 & -0.3 & -9.5 \\
\hline $\mathrm{Ni}$ & 16.0 & 22.5 & 0.5 & 7.3 & 10.7 & -0.3 & -4.9 \\
\hline $\mathrm{Cu}$ & 295.9 & 211.7 & -0.3 & -77.7 & 87.9 & -0.7 & -205.2 \\
\hline $\mathrm{Zn}$ & 239.2 & 290.2 & 0.3 & 59.8 & 283.3 & 0.2 & 53.3 \\
\hline Ga & 20.5 & 18.8 & -0.1 & -1.1 & 19.4 & 0.0 & -0.5 \\
\hline $\mathrm{Ge}$ & 4.6 & 5.3 & 0.2 & 0.9 & 4.2 & -0.1 & -0.2 \\
\hline As & 4.7 & 4.1 & -0.1 & -0.5 & 5.3 & 0.2 & 0.8 \\
\hline $\mathrm{Rb}$ & 80.0 & 62.9 & -0.2 & -15.2 & 74.0 & 0.0 & -3.6 \\
\hline $\mathrm{Sr}$ & 675.4 & 383.0 & -0.4 & -280.7 & 436.2 & -0.3 & -225.1 \\
\hline $\mathrm{Y}$ & 48.2 & 45.8 & 0 & 0 & 44.4 & 0.0 & -2.4 \\
\hline $\mathrm{Zr}$ & 351.2 & 333.9 & $\mathbf{0}$ & $\mathbf{0}$ & 334.4 & $\mathbf{0}$ & $\mathbf{0}$ \\
\hline $\mathrm{Nb}$ & 23.4 & 20.9 & -0.1 & -2.0 & 22.0 & 0.0 & -0.8 \\
\hline Mo & 1.7 & 2.6 & 0.6 & 1.1 & 1.2 & -0.3 & -0.4 \\
\hline Sn & 1.9 & 2.1 & 0.2 & 0.3 & 1.6 & -0.1 & -0.3 \\
\hline $\mathrm{Sb}$ & 0.7 & b.d. & - & - & b.d. & - & - \\
\hline $\mathrm{Te}$ & 2.0 & 1.6 & -0.2 & -0.4 & 3.6 & 0.9 & 1.7 \\
\hline Cs & 2.8 & 2.0 & -0.3 & -0.7 & 3.3 & 0.2 & 0.7 \\
\hline $\mathrm{Ba}$ & 1857.6 & 1137.9 & -0.4 & -685.0 & 1478.4 & -0.2 & -331.3 \\
\hline $\mathrm{La}$ & 124.5 & 110.5 & -0.1 & -10.6 & 113.4 & -0.1 & -7.4 \\
\hline $\mathrm{Ce}$ & 244.1 & 211.5 & -0.1 & -26.1 & 220.8 & -0.1 & -16.1 \\
\hline $\operatorname{Pr}$ & 25.8 & 22.3 & -0.1 & -2.8 & 23.3 & -0.1 & -1.7 \\
\hline $\mathrm{Nd}$ & 90.8 & 79.6 & -0.1 & -8.8 & 81.2 & -0.1 & -7.0 \\
\hline $\mathrm{Sm}$ & 13.2 & 12.2 & 0.0 & -0.6 & $\mathrm{x}$ & $\mathrm{x}$ & $\mathrm{x}$ \\
\hline $\mathrm{Eu}$ & 2.7 & 2.5 & 0.0 & -0.1 & 2.4 & -0.1 & -0.2 \\
\hline $\mathrm{Gd}$ & 10.6 & 9.0 & -0.1 & -1.4 & 9.6 & -0.1 & -0.8 \\
\hline $\mathrm{Tb}$ & 1.4 & $\mathrm{x}$ & $\mathrm{x}$ & $\mathrm{x}$ & 1.3 & 0.0 & 0.0 \\
\hline Dy & 8.9 & 7.9 & -0.1 & -0.7 & 8.0 & -0.1 & -0.6 \\
\hline Ho & 1.8 & 1.6 & -0.1 & -0.1 & 1.5 & -0.1 & -0.2 \\
\hline Er & 5.3 & 4.6 & -0.1 & -0.5 & 5.3 & 0.0 & 0.1 \\
\hline $\mathrm{Tm}$ & 0.7 & 0.7 & -0.1 & 0.0 & $\mathrm{x}$ & $\mathrm{x}$ & $\mathrm{x}$ \\
\hline $\mathrm{Yb}$ & 5.1 & 5.1 & 0.0 & 0.2 & 4.0 & -0.2 & -0.9 \\
\hline $\mathrm{Lu}$ & 0.8 & 0.6 & -0.2 & -0.1 & 0.6 & -0.2 & -0.2 \\
\hline $\mathrm{Hf}$ & 8.8 & 7.9 & -0.1 & -0.7 & 8.1 & -0.1 & -0.5 \\
\hline $\mathrm{Ta}$ & 1.4 & 1.6 & 0.2 & 0.2 & 1.6 & 0.2 & 0.2 \\
\hline W & 0.4 & 0.4 & 0.2 & 0.1 & $\mathrm{x}$ & $\mathrm{x}$ & $\mathrm{x}$ \\
\hline $\mathrm{Tl}$ & 0.3 & 0.2 & -0.3 & -0.1 & $\mathrm{x}$ & $x$ & $\mathrm{x}$ \\
\hline $\mathrm{Pb}$ & 12.3 & 8.1 & -0.3 & -4.0 & 11.1 & -0.1 & -0.9 \\
\hline $\mathrm{Bi}$ & 0.6 & 0.6 & 0.0 & 0.0 & b.d. & - & - \\
\hline Th & 36.5 & 33.0 & -0.1 & -2.5 & 33.1 & -0.1 & -2.3 \\
\hline $\mathrm{U}$ & 7.1 & 6.3 & -0.1 & -0.7 & 6.3 & -0.1 & -0.7 \\
\hline
\end{tabular}


Table 2. (Continued)

\begin{tabular}{|c|c|c|c|c|c|c|c|}
\hline \multirow[t]{2}{*}{ Sample } & \multirow{2}{*}{$\begin{array}{l}\text { PH645 } \\
\text { "Least } \\
\text { altered" }\end{array}$} & \multicolumn{3}{|c|}{ PH654 } & \multicolumn{3}{|c|}{ PH656 } \\
\hline & & Altered & $\begin{array}{l}\text { Gain/Loss } \\
\text { relative to } \mathrm{C}_{\mathrm{i}}{ }^{0}\end{array}$ & $\begin{array}{l}\text { Gain/Loss in } \\
\text { wt.\% or ppm }\end{array}$ & Altered & $\begin{array}{l}\text { Gain/Loss } \\
\text { relative to } \mathrm{C}_{\mathrm{i}}{ }^{0}\end{array}$ & $\begin{array}{l}\text { Gain/Loss in } \\
\text { wt.\% or ppm }\end{array}$ \\
\hline & $\mathrm{C}_{\mathrm{i}}{ }^{\mathrm{O}}$ & $\mathrm{C}_{\mathrm{i}}$ & $\Delta \mathrm{C}_{\mathrm{i}} / \mathrm{C}_{\mathrm{i}}{ }^{0}$ & $\Delta \mathrm{C}_{\mathrm{i}}$ & $\mathrm{C}_{\mathrm{i}}$ & $\Delta \mathrm{C}_{\mathrm{i}} / \mathrm{C}_{\mathrm{i}}^{0}$ & $\Delta \mathrm{C}_{\mathrm{i}}$ \\
\hline $\mathrm{SiO}_{2}$ (wt. \%) & 59.71 & 62.84 & $\mathbf{0}$ & $\mathbf{0}$ & 49.79 & -0.23 & -13.96 \\
\hline $\mathrm{TiO}_{2}$ & 1.12 & 1.12 & $\mathbf{0}$ & $\mathbf{0}$ & 1.32 & $\mathbf{0}$ & $\mathbf{0}$ \\
\hline $\mathrm{Al}_{2} \mathrm{O}_{3}$ & 15.88 & 15.45 & $\mathbf{0}$ & 0 & 15.74 & $\mathbf{0}$ & $\mathbf{0}$ \\
\hline $\mathrm{Fe}_{2} \mathrm{O}_{3}$ & 8.65 & 7.74 & -0.11 & -0.95 & 23.13 & 1.46 & 12.60 \\
\hline $\mathrm{MnO}$ & 1.06 & 0.72 & -0.32 & -0.34 & 0.45 & -0.61 & -0.65 \\
\hline MgO & 1.83 & 0.62 & -0.66 & -1.21 & 0.50 & -0.75 & -1.37 \\
\hline $\mathrm{CaO}$ & 1.29 & 0.96 & -0.26 & -0.33 & 0.61 & -0.57 & -0.73 \\
\hline $\mathrm{Na}_{2} \mathrm{O}$ & 4.67 & 3.91 & -0.17 & -0.78 & 0.07 & -0.99 & -4.60 \\
\hline $\mathrm{K}_{2} \mathrm{O}$ & 2.83 & 3.75 & 0.32 & 0.90 & 4.84 & 0.58 & 1.62 \\
\hline $\mathrm{P}_{2} \mathrm{O}_{5}$ & 0.42 & 0.43 & 0.03 & 0.01 & 0.42 & -0.08 & -0.03 \\
\hline Sc (ppm) & 10.9 & 12.0 & 0.1 & 1.1 & 6.9 & -0.4 & -4.5 \\
\hline $\mathrm{V}$ & 78.0 & 75.6 & 0.0 & -2.9 & $\mathrm{x}$ & $\mathrm{x}$ & $\mathrm{x}$ \\
\hline $\mathrm{Cr}$ & 8.9 & 11.2 & 0.3 & 2.3 & 17.3 & 0.8 & 7.0 \\
\hline Co & 35.8 & 25.9 & -0.3 & -10.0 & 19.5 & -0.5 & -17.8 \\
\hline $\mathrm{Ni}$ & 16.0 & 12.0 & -0.3 & -4.0 & 9.7 & -0.4 & -7.1 \\
\hline $\mathrm{Cu}$ & 295.9 & 102.7 & -0.7 & -193.8 & 28.8 & -0.9 & -269.4 \\
\hline $\mathrm{Zn}$ & 239.2 & 125.1 & -0.5 & -114.8 & 115.7 & -0.6 & -132.9 \\
\hline $\mathrm{Ga}$ & 20.5 & 15.8 & -0.2 & -4.8 & 28.6 & 0.3 & 5.8 \\
\hline $\mathrm{Ge}$ & 4.6 & 7.2 & 0.6 & 2.6 & $\mathrm{x}$ & $\mathrm{x}$ & $\mathrm{x}$ \\
\hline As & 4.7 & 5.6 & 0.2 & 0.8 & 14.7 & 1.9 & 8.8 \\
\hline $\mathrm{Rb}$ & 80.0 & 105.5 & 0.3 & 25.0 & 227.2 & 1.6 & 128.8 \\
\hline $\mathrm{Sr}$ & 675.4 & 286.3 & -0.6 & -390.8 & 55.5 & -0.9 & -624.4 \\
\hline Y & 48.2 & 39.8 & -0.2 & -8.6 & 45.4 & -0.1 & -6.5 \\
\hline $\mathrm{Zr}$ & 351.2 & 342.1 & $\mathbf{0}$ & 0 & 416.8 & 0 & $\mathbf{0}$ \\
\hline $\mathrm{Nb}$ & 23.4 & 22.0 & -0.1 & -1.5 & $\mathrm{x}$ & $\mathrm{x}$ & $\mathrm{x}$ \\
\hline Mo & 1.7 & 2.4 & 0.5 & 0.7 & 3.6 & 1.0 & 1.7 \\
\hline $\mathrm{Sn}$ & 1.9 & 2.2 & 0.2 & 0.3 & 1.9 & -0.1 & -0.2 \\
\hline $\mathrm{Sb}$ & 0.7 & 0.7 & 0.1 & 0.1 & 2.1 & 2.0 & 1.3 \\
\hline $\mathrm{Te}$ & 2.0 & b.d. & - & - & b.d. & - & - \\
\hline Cs & 2.8 & 3.8 & 0.4 & 1.0 & 7.8 & 1.6 & 4.4 \\
\hline $\mathrm{Ba}$ & 1857.6 & 3724.0 & 1.0 & 1845.0 & 1460.8 & -0.3 & -515.5 \\
\hline $\mathrm{La}$ & 124.5 & 118.3 & -0.1 & -6.9 & 180.2 & 0.3 & 41.1 \\
\hline $\mathrm{Ce}$ & 244.1 & 227.9 & -0.1 & -17.5 & $\mathrm{x}$ & $\mathrm{x}$ & $\mathrm{x}$ \\
\hline $\mathrm{Pr}$ & 25.8 & 23.7 & -0.1 & -2.2 & 25.1 & -0.1 & -2.7 \\
\hline $\mathrm{Nd}$ & 90.8 & 82.1 & -0.1 & -9.1 & 80.6 & -0.2 & -16.7 \\
\hline $\mathrm{Sm}$ & 13.2 & 11.7 & -0.1 & -1.6 & 9.3 & -0.4 & -4.7 \\
\hline $\mathrm{Eu}$ & 2.7 & 2.1 & -0.2 & -0.6 & 2.3 & -0.2 & -0.5 \\
\hline Gd & 10.6 & 9.4 & -0.1 & -1.3 & 6.9 & -0.4 & -4.3 \\
\hline $\mathrm{Tb}$ & 1.4 & 1.3 & -0.1 & -0.1 & 1.1 & -0.3 & -0.4 \\
\hline Dy & 8.9 & 7.4 & -0.2 & -1.5 & 7.0 & -0.3 & -2.4 \\
\hline Но & 1.8 & 1.5 & -0.2 & -0.3 & 1.4 & -0.3 & -0.5 \\
\hline $\mathrm{Er}$ & 5.3 & 4.5 & -0.2 & -0.8 & 5.6 & 0.0 & -0.2 \\
\hline $\mathrm{Tm}$ & 0.7 & 0.7 & -0.1 & -0.1 & $\mathrm{x}$ & $\mathrm{x}$ & $\mathrm{x}$ \\
\hline $\mathrm{Yb}$ & 5.1 & 4.5 & -0.1 & -0.5 & 6.1 & 0.1 & 0.6 \\
\hline $\mathrm{Lu}$ & 0.8 & 0.7 & -0.1 & -0.1 & $x$ & $\mathrm{x}$ & $\mathrm{x}$ \\
\hline $\mathrm{Hf}$ & 8.8 & $\mathrm{x}$ & $\mathrm{x}$ & $\mathrm{x}$ & $\mathrm{x}$ & $\mathrm{x}$ & $\mathrm{x}$ \\
\hline $\mathrm{Ta}$ & 1.4 & $\mathrm{x}$ & $\mathrm{x}$ & $\mathrm{x}$ & 1.7 & 0.1 & 0.2 \\
\hline W & 0.4 & 0.6 & 0.5 & 0.2 & 1.8 & 3.5 & 1.3 \\
\hline $\mathrm{Tl}$ & 0.3 & 0.5 & 0.7 & 0.2 & 0.7 & 1.4 & 0.4 \\
\hline $\mathrm{Pb}$ & 12.3 & 20.7 & 0.7 & 8.3 & 34.3 & 1.6 & 19.2 \\
\hline $\mathrm{Bi}$ & 0.6 & $\mathrm{x}$ & $\mathrm{x}$ & $\mathrm{x}$ & 1.3 & 0.9 & 0.5 \\
\hline Th & 36.5 & 34.7 & -0.1 & -2.0 & $\mathrm{x}$ & $\mathrm{x}$ & $\mathrm{x}$ \\
\hline $\mathrm{U}$ & 7.1 & $\mathrm{x}$ & $\mathrm{x}$ & $\mathrm{x}$ & 6.8 & -0.1 & -0.9 \\
\hline
\end{tabular}


Table 2. (Continued)

\begin{tabular}{|c|c|c|c|c|c|c|c|}
\hline \multirow[t]{2}{*}{ Sample } & \multirow{2}{*}{$\begin{array}{l}\text { PH645 } \\
\text { "Least } \\
\text { altered" }\end{array}$} & \multicolumn{3}{|c|}{ PH655 } & \multicolumn{3}{|c|}{ XРH656 } \\
\hline & & Altered & $\begin{array}{l}\text { Gain/Loss } \\
\text { relative to } \mathrm{C}_{\mathrm{i}}{ }^{0}\end{array}$ & $\begin{array}{l}\text { Gain/Loss in } \\
\text { wt.\% or ppm }\end{array}$ & Altered & $\begin{array}{l}\text { Gain/Loss } \\
\text { relative to } \mathrm{C}_{\mathrm{i}}{ }^{0}\end{array}$ & $\begin{array}{l}\text { Gain/Loss in } \\
\text { wt.\% or ppm }\end{array}$ \\
\hline & $\mathrm{C}_{\mathrm{i}}{ }^{\mathrm{O}}$ & $\mathrm{C}_{\mathrm{i}}$ & $\Delta \mathrm{C}_{\mathrm{i}} / \mathrm{C}_{\mathrm{i}}{ }^{0}$ & $\Delta \mathrm{C}_{\mathrm{i}}$ & $\mathrm{C}_{\mathrm{i}}$ & $\Delta \mathrm{C}_{\mathrm{i}} / \mathrm{C}_{\mathrm{i}}^{0}$ & $\Delta \mathrm{C}_{\mathrm{i}}$ \\
\hline $\mathrm{SiO}_{2}$ (wt. \%) & 59.71 & 47.98 & -0.05 & -2.84 & 43.88 & 2.20 & 131.37 \\
\hline $\mathrm{TiO}_{2}$ & 1.12 & 0.95 & $\mathbf{0}$ & $\mathbf{0}$ & 0.22 & -0.13 & -0.14 \\
\hline $\mathrm{Al}_{2} \mathrm{O}_{3}$ & 15.88 & 8.08 & -0.40 & -6.30 & 2.71 & -0.26 & -4.10 \\
\hline $\mathrm{Fe}_{2} \mathrm{O}_{3}$ & 8.65 & 35.66 & 3.89 & 33.62 & 49.45 & 23.91 & 206.7 \\
\hline $\mathrm{MnO}$ & 1.06 & 0.26 & -0.71 & -0.75 & 0.35 & 0.44 & 0.46 \\
\hline MgO & 1.83 & 0.35 & -0.77 & -1.41 & 0.15 & -0.65 & -1.19 \\
\hline $\mathrm{CaO}$ & 1.29 & 0.83 & -0.24 & -0.31 & 0.67 & 1.25 & 1.62 \\
\hline $\mathrm{Na}_{2} \mathrm{O}$ & 4.67 & 0.06 & -0.98 & -4.60 & 0.04 & -0.96 & -4.50 \\
\hline $\mathrm{K}_{2} \mathrm{O}$ & 2.83 & 2.57 & 0.08 & 0.22 & 0.69 & 0.06 & 0.16 \\
\hline $\mathrm{P}_{2} \mathrm{O}_{5}$ & 0.42 & 0.50 & 0.42 & 0.17 & 0.23 & 1.35 & 0.57 \\
\hline Sc (ppm) & 10.9 & 5.9 & -0.4 & -3.9 & 2.0 & -0.2 & -2.3 \\
\hline V & 78.0 & 53.9 & -0.2 & -14.1 & 51.4 & 1.9 & 145.9 \\
\hline $\mathrm{Cr}$ & 8.9 & 12.0 & 0.6 & 5.3 & 24.5 & 11.0 & 97.7 \\
\hline Co & 35.8 & 9.9 & -0.7 & -24.0 & 13.3 & 0.6 & 22.1 \\
\hline $\mathrm{Ni}$ & 16.0 & 7.9 & -0.4 & -6.6 & 18.8 & 4.1 & 65.9 \\
\hline $\mathrm{Cu}$ & 295.9 & 94.9 & -0.6 & -183.4 & 157.1 & 1.3 & 388.2 \\
\hline $\mathrm{Zn}$ & 239.2 & 76.4 & -0.6 & -148.6 & 73.7 & 0.3 & 81.9 \\
\hline $\mathrm{Ga}$ & 20.5 & 15.7 & -0.1 & -1.9 & 6.1 & 0.3 & 6.0 \\
\hline $\mathrm{Ge}$ & 4.6 & 8.1 & 1.1 & 5.0 & 5.1 & 3.8 & 17.4 \\
\hline As & 4.7 & 166.1 & 40.8 & 192.2 & 70.4 & 64.0 & 301.7 \\
\hline $\mathrm{Rb}$ & 80.0 & 124.0 & 0.8 & 67.0 & 34.4 & 0.9 & 70.0 \\
\hline $\mathrm{Sr}$ & 675.4 & 82.0 & -0.9 & -578.2 & 50.3 & -0.7 & -456.2 \\
\hline Y & 48.2 & 31.1 & -0.2 & -11.3 & 10.8 & 0.0 & -1.3 \\
\hline $\mathrm{Zr}$ & 351.2 & 294.7 & 0 & 0 & 80.6 & 0 & 0 \\
\hline $\mathrm{Nb}$ & 23.4 & 19.0 & 0.0 & -0.9 & 4.3 & -0.2 & -4.9 \\
\hline Mo & 1.7 & 13.0 & 8.3 & 13.8 & 12.6 & 32.0 & 53.0 \\
\hline $\mathrm{Sn}$ & 1.9 & 3.3 & 1.1 & 2.1 & 2.0 & 3.7 & 7.0 \\
\hline $\mathrm{Sb}$ & 0.7 & 7.9 & 13.1 & 8.7 & 4.9 & 31.2 & 20.5 \\
\hline $\mathrm{Te}$ & 2.0 & b.d. & - & - & b.d. & - & - \\
\hline Cs & 2.8 & 3.6 & 0.5 & 1.5 & 1.5 & 1.3 & 3.7 \\
\hline $\mathrm{Ba}$ & 1857.6 & 779.0 & -0.5 & -934.2 & 612.8 & 0.4 & 810.7 \\
\hline $\mathrm{La}$ & 124.5 & 143.7 & 0.4 & 45.8 & 25.3 & -0.1 & -14.5 \\
\hline $\mathrm{Ce}$ & 244.1 & 214.7 & 0.0 & 10.4 & 44.1 & -0.2 & -51.9 \\
\hline $\mathrm{Pr}$ & 25.8 & 20.1 & -0.1 & -2.0 & 4.6 & -0.2 & -5.7 \\
\hline $\mathrm{Nd}$ & 90.8 & 65.0 & -0.2 & -13.7 & 17.0 & -0.2 & -16.9 \\
\hline $\mathrm{Sm}$ & 13.2 & 7.5 & -0.3 & -4.4 & 2.6 & -0.2 & -2.0 \\
\hline $\mathrm{Eu}$ & 2.7 & 2.2 & 0.0 & -0.1 & 0.8 & 0.4 & 1.0 \\
\hline $\mathrm{Gd}$ & 10.6 & 6.5 & -0.3 & -2.9 & 2.2 & -0.1 & -0.9 \\
\hline $\mathrm{Tb}$ & 1.4 & 0.7 & -0.4 & -0.5 & 0.3 & 0.0 & 0.0 \\
\hline Dy & 8.9 & 4.8 & -0.4 & -3.2 & 1.9 & -0.1 & -0.6 \\
\hline Но & 1.8 & 1.1 & -0.3 & -0.5 & 0.3 & -0.2 & -0.3 \\
\hline $\mathrm{Er}$ & 5.3 & 3.3 & -0.3 & -1.4 & 1.2 & 0.0 & -0.2 \\
\hline $\mathrm{Tm}$ & 0.7 & 0.5 & -0.2 & -0.1 & 0.2 & 0.3 & 0.2 \\
\hline $\mathrm{Yb}$ & 5.1 & 3.7 & -0.1 & -0.7 & 0.9 & -0.2 & -1.0 \\
\hline $\mathrm{Lu}$ & 0.8 & 0.6 & 0.0 & 0.0 & 0.2 & 0.2 & 0.1 \\
\hline $\mathrm{Hf}$ & 8.8 & 7.7 & 0.0 & 0.3 & 2.5 & 0.2 & 2.0 \\
\hline $\mathrm{Ta}$ & 1.4 & 1.1 & 0.0 & 0.0 & 0.2 & -0.5 & -0.6 \\
\hline $\mathrm{W}$ & 0.4 & 5.7 & 16.8 & 6.4 & 5.9 & 67.0 & 25.4 \\
\hline $\mathrm{Tl}$ & 0.3 & 0.3 & 0.3 & 0.1 & 0.0 & -0.4 & -0.1 \\
\hline $\mathrm{Pb}$ & 12.3 & 61.3 & 4.9 & 60.3 & 48.9 & 16.3 & 200.4 \\
\hline $\mathrm{Bi}$ & 0.6 & 3.2 & 5.3 & 3.2 & 3.5 & 24.3 & 14.7 \\
\hline Th & 36.5 & 23.6 & -0.2 & -8.5 & 7.2 & -0.1 & -5.3 \\
\hline $\mathrm{U}$ & 7.1 & 6.8 & 0.1 & 0.9 & 4.4 & 1.7 & 12.2 \\
\hline
\end{tabular}


Table 2. (Continued)

\begin{tabular}{|c|c|c|c|c|c|c|c|}
\hline \multirow[t]{2}{*}{ Sample } & \multirow{2}{*}{$\begin{array}{l}\text { PH621 } \\
\text { "Least } \\
\text { altered" }\end{array}$} & \multicolumn{3}{|c|}{ PH658 } & \multicolumn{3}{|c|}{ ХРН659B } \\
\hline & & Altered & $\begin{array}{l}\text { Gain/Loss } \\
\text { relative to } \mathrm{C}_{\mathrm{i}}{ }^{0}\end{array}$ & $\begin{array}{l}\text { Gain/Loss in } \\
\text { wt.\% or ppm }\end{array}$ & Altered & $\begin{array}{l}\text { Gain/Loss } \\
\text { relative to } \mathrm{C}_{\mathrm{i}}{ }^{0}\end{array}$ & $\begin{array}{l}\text { Gain/Loss in } \\
\text { wt.\% or ppm }\end{array}$ \\
\hline & $\mathrm{C}_{\mathrm{i}}{ }^{\mathrm{O}}$ & $\mathrm{C}_{\mathrm{i}}$ & $\Delta \mathrm{C}_{\mathrm{i}} / \mathrm{C}_{\mathrm{i}}^{0}$ & $\Delta \mathrm{C}_{\mathrm{i}}$ & $\mathrm{C}_{\mathrm{i}}$ & $\Delta \mathrm{C}_{\mathrm{i}} / \mathrm{C}_{\mathrm{i}}^{0}$ & $\Delta \mathrm{C}_{\mathrm{i}}$ \\
\hline $\mathrm{SiO}_{2}$ (wt. \%) & 51.37 & 56.82 & 0 & $\overline{0}$ & 56.09 & 0.14 & 7.44 \\
\hline $\mathrm{TiO}_{2}$ & 1.12 & 1.04 & $\mathbf{0}$ & $\mathbf{0}$ & 1.06 & $\mathbf{0}$ & $\mathbf{0}$ \\
\hline $\mathrm{Al}_{2} \mathrm{O}_{3}$ & 16.52 & 13.06 & -0.21 & -3.49 & 11.28 & -0.28 & -4.69 \\
\hline $\mathrm{Fe}_{2} \mathrm{O}_{3}$ & 10.59 & 11.49 & 0.08 & 0.87 & 16.53 & 0.64 & 6.74 \\
\hline $\mathrm{MnO}$ & 0.55 & 0.37 & -0.34 & -0.19 & 0.77 & 0.45 & 0.25 \\
\hline MgO & 5.24 & 1.08 & -0.79 & -4.16 & 1.22 & -0.76 & -3.96 \\
\hline $\mathrm{CaO}$ & 3.69 & 0.71 & -0.81 & -2.99 & 1.67 & -0.53 & -1.94 \\
\hline $\mathrm{Na}_{2} \mathrm{O}$ & 3.72 & 0.08 & -0.98 & -3.64 & 0.07 & -0.98 & -3.65 \\
\hline $\mathrm{K}_{2} \mathrm{O}$ & 3.95 & 7.39 & 0.86 & 3.41 & 5.89 & 0.56 & 2.22 \\
\hline $\mathrm{P}_{2} \mathrm{O}_{5}$ & 0.39 & 0.38 & $\mathbf{0}$ & $\mathbf{0}$ & 0.34 & -0.10 & -0.04 \\
\hline Sc (ppm) & 21.96 & 11.81 & -0.46 & -10.18 & 7.35 & -0.65 & -14.25 \\
\hline $\mathrm{V}$ & 154.28 & 65.66 & -0.58 & -88.80 & 117.66 & -0.20 & -30.91 \\
\hline $\mathrm{Cr}$ & 146.97 & 6.70 & -0.95 & -140.29 & 9.84 & -0.93 & -136.65 \\
\hline Co & 31.26 & 39.60 & 0.26 & 8.24 & 114.67 & 2.85 & 88.97 \\
\hline $\mathrm{Ni}$ & 49.00 & 9.95 & -0.80 & -39.09 & 29.81 & -0.36 & -17.75 \\
\hline $\mathrm{Cu}$ & 11.60 & 374.60 & 31.21 & 361.98 & 1712.50 & 153.79 & 1783.95 \\
\hline $\mathrm{Zn}$ & 319.41 & 143.05 & -0.55 & -176.74 & 203.76 & -0.33 & -105.76 \\
\hline $\mathrm{Ga}$ & 15.58 & 17.33 & 0.11 & 1.70 & 10.51 & -0.29 & -4.55 \\
\hline $\mathrm{Ge}$ & 5.02 & 5.83 & 0.16 & 0.79 & 3.72 & -0.22 & -1.13 \\
\hline As & 13.00 & 5.54 & -0.58 & -7.48 & 65.89 & 4.31 & 56.08 \\
\hline $\mathrm{Rb}$ & 108.49 & 202.79 & 0.86 & 93.75 & 105.51 & 0.02 & 2.14 \\
\hline $\mathrm{Sr}$ & 529.11 & 69.65 & -0.87 & -459.65 & 50.90 & -0.90 & -475.75 \\
\hline Y & 23.68 & 43.25 & 0.82 & 19.45 & 33.53 & 0.48 & 11.47 \\
\hline $\mathrm{Zr}$ & 175.38 & 386.39 & 1.20 & 209.96 & 403.10 & 1.41 & 247.27 \\
\hline $\mathrm{Nb}$ & 9.19 & 24.91 & 1.70 & 15.65 & 25.51 & 1.91 & 17.56 \\
\hline Mo & 2.50 & 4.55 & 0.82 & 2.04 & 7.86 & 2.30 & 5.75 \\
\hline $\mathrm{Sn}$ & 1.41 & 2.69 & 0.91 & 1.28 & 3.94 & 1.93 & 2.72 \\
\hline $\mathrm{Sb}$ & 3.08 & 1.65 & -0.47 & -1.43 & 1.68 & -0.43 & -1.32 \\
\hline $\mathrm{Te}$ & 1.63 & b.d. & - & - & b.d. & - & - \\
\hline Cs & 0.77 & 2.41 & 2.11 & 1.63 & 0.11 & -0.85 & -0.65 \\
\hline $\mathrm{Ba}$ & 1835.38 & 2830.12 & 0.54 & 987.06 & 6076.36 & 2.47 & 4535.66 \\
\hline $\mathrm{La}$ & 38.28 & 146.73 & 2.82 & 108.04 & 109.52 & 2.00 & 76.54 \\
\hline $\mathrm{Ce}$ & 78.16 & 263.21 & 2.36 & 184.34 & 186.25 & 1.50 & 117.12 \\
\hline $\mathrm{Pr}$ & 8.97 & 26.60 & 1.96 & 17.56 & 16.78 & 0.96 & 8.62 \\
\hline $\mathrm{Nd}$ & 35.11 & 90.81 & 1.58 & 55.46 & 52.55 & 0.57 & 19.99 \\
\hline $\mathrm{Sm}$ & 6.01 & 12.75 & 1.12 & 6.71 & 6.41 & 0.12 & 0.71 \\
\hline $\mathrm{Eu}$ & 1.63 & 2.71 & 0.66 & 1.08 & 2.82 & 0.82 & 1.33 \\
\hline Gd & 4.60 & 9.89 & 1.15 & 5.27 & 6.49 & 0.48 & 2.20 \\
\hline $\mathrm{Tb}$ & 0.75 & 1.34 & 0.77 & 0.58 & 0.84 & 0.16 & 0.12 \\
\hline Dy & 4.02 & 7.97 & 0.97 & 3.92 & 5.49 & 0.43 & 1.73 \\
\hline Но & 0.92 & 1.82 & 0.96 & 0.89 & 1.25 & 0.42 & 0.38 \\
\hline $\mathrm{Er}$ & 2.52 & 4.88 & 0.93 & 2.34 & 4.15 & 0.72 & 1.82 \\
\hline $\mathrm{Tm}$ & 0.33 & 0.80 & 1.40 & 0.47 & 0.56 & 0.75 & 0.25 \\
\hline $\mathrm{Yb}$ & 2.40 & 5.33 & 1.22 & 2.92 & 4.87 & 1.13 & 2.70 \\
\hline $\mathrm{Lu}$ & 0.32 & 0.79 & 1.44 & 0.47 & 0.82 & 1.64 & 0.53 \\
\hline $\mathrm{Hf}$ & 4.30 & 10.16 & 1.35 & 5.83 & 9.91 & 1.41 & 6.09 \\
\hline $\mathrm{Ta}$ & 0.64 & 1.49 & 1.34 & 0.85 & 1.89 & 2.13 & 1.35 \\
\hline $\mathrm{W}$ & 0.47 & 0.56 & 0.17 & 0.08 & 4.14 & 8.16 & 3.87 \\
\hline $\mathrm{Tl}$ & 0.53 & 1.36 & 1.56 & 0.83 & 0.82 & 0.61 & 0.32 \\
\hline $\mathrm{Pb}$ & 8.87 & 13.11 & 0.47 & 4.20 & 8.40 & -0.01 & -0.07 \\
\hline $\mathrm{Bi}$ & 0.06 & 0.55 & 7.52 & 0.48 & 0.40 & 5.51 & 0.35 \\
\hline Th & 6.89 & 39.59 & 4.73 & 32.59 & 31.21 & 3.75 & 25.83 \\
\hline $\mathrm{U}$ & 0.94 & 9.22 & 8.78 & 8.25 & 9.46 & 9.55 & 8.98 \\
\hline
\end{tabular}


Table 2. (Continued)

\begin{tabular}{|c|c|c|c|c|c|c|c|}
\hline \multirow[t]{2}{*}{ Sample } & \multirow{2}{*}{$\begin{array}{l}\text { PH621 } \\
\text { "Least } \\
\text { altered" }\end{array}$} & \multicolumn{3}{|c|}{ PH659A } & \multicolumn{3}{|c|}{ ХРH660 } \\
\hline & & Altered & $\begin{array}{l}\text { Gain/Loss } \\
\text { relative to } \mathrm{C}_{\mathrm{i}}{ }^{0}\end{array}$ & $\begin{array}{l}\text { Gain/Loss in } \\
\text { wt.\% or ppm }\end{array}$ & Altered & $\begin{array}{l}\text { Gain/Loss } \\
\text { relative to } \mathrm{C}_{\mathrm{i}}{ }^{0}\end{array}$ & $\begin{array}{l}\text { Gain/Loss in } \\
\text { wt.\% or ppm }\end{array}$ \\
\hline & $\mathrm{C}_{\mathrm{i}}{ }^{\mathrm{O}}$ & $\mathrm{C}_{\mathrm{i}}$ & $\Delta \mathrm{C}_{\mathrm{i}} / \mathrm{C}_{\mathrm{i}}{ }^{0}$ & $\Delta \mathrm{C}_{\mathrm{i}}$ & $\mathrm{C}_{\mathrm{i}}$ & $\Delta \mathrm{C}_{\mathrm{i}} / \mathrm{C}_{\mathrm{i}}^{0}$ & $\Delta \mathrm{C}_{\mathrm{i}}$ \\
\hline $\mathrm{SiO}_{2}$ (wt. \%) & 51.37 & 56.09 & 0.14 & 7.44 & 43.31 & 0.68 & 34.69 \\
\hline $\mathrm{TiO}_{2}$ & 1.12 & 1.06 & $\mathbf{0}$ & $\mathbf{0}$ & 0.56 & $\mathbf{0}$ & 0 \\
\hline $\mathrm{Al}_{2} \mathrm{O}_{3}$ & 16.52 & 11.28 & -0.28 & -4.69 & 5.99 & -0.28 & -4.62 \\
\hline $\mathrm{Fe}_{2} \mathrm{O}_{3}$ & 10.59 & 16.53 & 0.64 & 6.74 & 38.82 & 6.28 & 66.55 \\
\hline $\mathrm{MnO}$ & 0.55 & 0.77 & 0.45 & 0.25 & 0.74 & 1.66 & 0.92 \\
\hline MgO & 5.24 & 1.22 & -0.76 & -3.96 & 1.09 & -0.59 & -3.08 \\
\hline $\mathrm{CaO}$ & 3.69 & 1.67 & -0.53 & -1.94 & 2.53 & 0.36 & 1.32 \\
\hline $\mathrm{Na}_{2} \mathrm{O}$ & 3.72 & 0.07 & -0.98 & -3.65 & 0.04 & -0.98 & -3.65 \\
\hline $\mathrm{K}_{2} \mathrm{O}$ & 3.95 & 5.89 & 0.56 & 2.22 & 1.56 & -0.22 & -0.86 \\
\hline $\mathrm{P}_{2} \mathrm{O}_{5}$ & 0.39 & 0.34 & -0.10 & -0.04 & 1.03 & 4.17 & 1.64 \\
\hline Sc (ppm) & 21.96 & 7.35 & -0.65 & -14.25 & 4.64 & -0.58 & -12.73 \\
\hline $\mathrm{V}$ & 154.28 & 117.66 & -0.20 & -30.91 & 323.45 & 3.17 & 488.45 \\
\hline $\mathrm{Cr}$ & 146.97 & 9.84 & -0.93 & -136.65 & 12.01 & -0.84 & -123.10 \\
\hline Co & 31.26 & 114.67 & 2.85 & 88.97 & 313.48 & 18.93 & 591.66 \\
\hline $\mathrm{Ni}$ & 49.00 & 29.81 & -0.36 & -17.75 & 53.22 & 1.16 & 56.74 \\
\hline $\mathrm{Cu}$ & 11.60 & 1712.50 & 153.79 & 1783.95 & 4791.00 & 819.72 & 9508.70 \\
\hline $\mathrm{Zn}$ & 319.41 & 203.76 & -0.33 & -105.76 & 190.36 & 0.18 & 58.86 \\
\hline Ga & 15.58 & 10.51 & -0.29 & -4.55 & 12.98 & 0.66 & 10.21 \\
\hline $\mathrm{Ge}$ & 5.02 & 3.72 & -0.22 & -1.13 & 7.86 & 2.11 & 10.60 \\
\hline As & 13.00 & 65.89 & 4.31 & 56.08 & 312.21 & 46.71 & 607.40 \\
\hline $\mathrm{Rb}$ & 108.49 & 105.51 & 0.02 & 2.14 & 28.42 & -0.48 & -52.02 \\
\hline $\mathrm{Sr}$ & 529.11 & 50.90 & -0.90 & -475.75 & 26.04 & -0.90 & -477.36 \\
\hline Y & 23.68 & 33.53 & 0.48 & 11.47 & 18.38 & 0.54 & 12.84 \\
\hline $\mathrm{Zr}$ & 175.38 & 403.10 & 1.41 & 247.27 & 170.68 & 0.93 & 163.78 \\
\hline $\mathrm{Nb}$ & 9.19 & 25.51 & 1.91 & 17.56 & 4.19 & -0.09 & -0.87 \\
\hline Mo & 2.50 & 7.86 & 2.30 & 5.75 & 22.22 & 16.69 & 41.65 \\
\hline $\mathrm{Sn}$ & 1.41 & 3.94 & 1.93 & 2.72 & 4.41 & 5.23 & 7.35 \\
\hline $\mathrm{Sb}$ & 3.08 & 1.68 & -0.43 & -1.32 & 3.38 & 1.18 & 3.63 \\
\hline $\mathrm{Te}$ & 1.63 & b.d. & - & - & 2.40 & 1.93 & 3.14 \\
\hline Cs & 0.77 & 0.11 & -0.85 & -0.65 & - & - & - \\
\hline $\mathrm{Ba}$ & 1835.38 & 6076.36 & 2.47 & 4535.66 & 1079.69 & 0.17 & 310.08 \\
\hline $\mathrm{La}$ & 38.28 & 109.52 & 2.00 & 76.54 & 158.35 & 7.22 & 276.38 \\
\hline $\mathrm{Ce}$ & 78.16 & 186.25 & 1.50 & 117.12 & 248.11 & 5.31 & 414.85 \\
\hline $\mathrm{Pr}$ & 8.97 & 16.78 & 0.96 & 8.62 & 22.16 & 3.91 & 35.07 \\
\hline $\mathrm{Nd}$ & 35.11 & 52.55 & 0.57 & 19.99 & 67.21 & 2.80 & 98.44 \\
\hline $\mathrm{Sm}$ & 6.01 & 6.41 & 0.12 & 0.71 & 6.93 & 1.29 & 7.75 \\
\hline $\mathrm{Eu}$ & 1.63 & 2.82 & 0.82 & 1.33 & 2.66 & 2.25 & 3.66 \\
\hline Gd & 4.60 & 6.49 & 0.48 & 2.20 & 5.22 & 1.26 & 5.77 \\
\hline $\mathrm{Tb}$ & 0.75 & 0.84 & 0.16 & 0.12 & 0.63 & 0.67 & 0.51 \\
\hline Dy & 4.02 & 5.49 & 0.43 & 1.73 & 3.89 & 0.92 & 3.70 \\
\hline Но & 0.92 & 1.25 & 0.42 & 0.38 & 0.72 & 0.56 & 0.52 \\
\hline $\mathrm{Er}$ & 2.52 & 4.15 & 0.72 & 1.82 & 2.27 & 0.79 & 1.99 \\
\hline $\mathrm{Tm}$ & 0.33 & 0.56 & 0.75 & 0.25 & 0.27 & 0.61 & 0.20 \\
\hline $\mathrm{Yb}$ & 2.40 & 4.87 & 1.13 & 2.70 & 1.84 & 0.52 & 1.25 \\
\hline $\mathrm{Lu}$ & 0.32 & 0.82 & 1.64 & 0.53 & 0.35 & 1.12 & 0.36 \\
\hline $\mathrm{Hf}$ & 4.30 & 9.91 & 1.41 & 6.09 & 4.44 & 1.05 & 4.51 \\
\hline $\mathrm{Ta}$ & 0.64 & 1.89 & 2.13 & 1.35 & 0.20 & -0.37 & -0.23 \\
\hline $\mathrm{W}$ & 0.47 & 4.14 & 8.16 & 3.87 & 4.44 & 17.60 & 8.34 \\
\hline $\mathrm{Tl}$ & 0.53 & 0.82 & 0.61 & 0.32 & 0.18 & -0.33 & -0.18 \\
\hline $\mathrm{Pb}$ & 8.87 & 8.40 & -0.01 & -0.07 & 11.60 & 1.60 & 14.17 \\
\hline $\mathrm{Bi}$ & 0.06 & 0.40 & 5.51 & 0.35 & 1.60 & 48.92 & 3.12 \\
\hline Th & 6.89 & 31.21 & 3.75 & 25.83 & 15.14 & 3.36 & 23.19 \\
\hline $\mathrm{U}$ & 0.94 & 9.46 & 9.55 & 8.98 & 5.30 & 10.20 & 9.59 \\
\hline
\end{tabular}


Table 2. (Continued)

\begin{tabular}{|c|c|c|c|c|c|c|c|}
\hline \multirow[t]{2}{*}{ Sample } & \multirow{2}{*}{$\begin{array}{l}\text { PH621 } \\
\text { "Least } \\
\text { altered" }\end{array}$} & \multicolumn{3}{|c|}{ PH661 } & \multicolumn{3}{|c|}{ PH662 } \\
\hline & & Altered & $\begin{array}{l}\text { Gain/Loss } \\
\text { relative to } \mathrm{C}_{\mathrm{i}}{ }^{0}\end{array}$ & $\begin{array}{l}\text { Gain/Loss in } \\
\text { wt.\% or ppm }\end{array}$ & Altered & $\begin{array}{l}\text { Gain/Loss } \\
\text { relative to } \mathrm{C}_{\mathrm{i}}{ }^{0}\end{array}$ & $\begin{array}{l}\text { Gain/Loss in } \\
\text { wt.\% or ppm }\end{array}$ \\
\hline & $\mathrm{C}_{\mathrm{i}}{ }^{\mathrm{O}}$ & $\mathrm{C}_{\mathrm{i}}$ & $\Delta \mathrm{C}_{\mathrm{i}} / \mathrm{C}_{\mathrm{i}}{ }^{0}$ & $\Delta \mathrm{C}_{\mathrm{i}}$ & $\mathrm{C}_{\mathrm{i}}$ & $\Delta \mathrm{C}_{\mathrm{i}} / \mathrm{C}_{\mathrm{i}}^{0}$ & $\Delta \mathrm{C}_{\mathrm{i}}$ \\
\hline $\mathrm{SiO}_{2}$ (wt. \%) & 51.37 & 51.86 & 0.81 & 41.65 & 26.29 & -0.51 & -26.34 \\
\hline $\mathrm{TiO}_{2}$ & 1.12 & 0.62 & $\mathbf{0}$ & 0 & 1.17 & $\mathbf{0}$ & 0 \\
\hline $\mathrm{Al}_{2} \mathrm{O}_{3}$ & 16.52 & 5.92 & -0.36 & -5.89 & 0.80 & -0.95 & -15.75 \\
\hline $\mathrm{Fe}_{2} \mathrm{O}_{3}$ & 10.59 & 30.47 & 4.16 & 44.06 & 61.53 & 4.53 & 48.00 \\
\hline $\mathrm{MnO}$ & 0.55 & 0.77 & 1.49 & 0.83 & 0.33 & -0.44 & -0.24 \\
\hline MgO & 5.24 & 1.16 & -0.60 & -3.16 & 0.65 & -0.88 & -4.62 \\
\hline $\mathrm{CaO}$ & 3.69 & 2.47 & 0.20 & 0.74 & 3.42 & -0.12 & -0.44 \\
\hline $\mathrm{Na}_{2} \mathrm{O}$ & 3.72 & 0.04 & -0.98 & -3.65 & 0.02 & -1.00 & -3.71 \\
\hline $\mathrm{K}_{2} \mathrm{O}$ & 3.95 & 1.26 & -0.43 & -1.70 & 0.01 & -1.00 & -3.95 \\
\hline $\mathrm{P}_{2} \mathrm{O}_{5}$ & 0.39 & 0.80 & 2.64 & 1.04 & 1.55 & 2.75 & 1.08 \\
\hline Sc (ppm) & 21.96 & 3.59 & -0.71 & -15.52 & 3.56 & -0.85 & -18.57 \\
\hline $\mathrm{V}$ & 154.28 & 208.90 & 1.43 & 220.43 & 538.07 & 2.32 & 358.11 \\
\hline $\mathrm{Cr}$ & 146.97 & 9.69 & -0.88 & -129.59 & 25.48 & -0.83 & -122.70 \\
\hline Co & 31.26 & 278.79 & 15.00 & 468.81 & 105.84 & 2.22 & 69.53 \\
\hline $\mathrm{Ni}$ & 49.00 & 35.30 & 0.29 & 14.32 & 49.66 & -0.03 & -1.71 \\
\hline $\mathrm{Cu}$ & 11.60 & 3004.60 & 463.61 & 5377.86 & 10127 & 830.32 & 9631.77 \\
\hline $\mathrm{Zn}$ & 319.41 & 190.20 & 0.07 & 21.77 & 46.85 & -0.86 & -274.80 \\
\hline Ga & 15.58 & 10.69 & 0.23 & 3.59 & 11.47 & -0.30 & -4.65 \\
\hline $\mathrm{Ge}$ & 5.02 & 5.83 & 1.08 & 5.43 & 6.96 & 0.32 & 1.60 \\
\hline As & 13.00 & 254.47 & 34.10 & 443.45 & 79.56 & 4.83 & 62.76 \\
\hline $\mathrm{Rb}$ & 108.49 & 22.77 & -0.62 & -67.65 & 0.37 & -1.00 & -108.13 \\
\hline $\mathrm{Sr}$ & 529.11 & 31.32 & -0.89 & -472.94 & 40.82 & -0.93 & -490.24 \\
\hline Y & 23.68 & 20.48 & 0.55 & 13.06 & 19.91 & -0.20 & -4.72 \\
\hline $\mathrm{Zr}$ & 175.38 & 222.61 & 1.28 & 223.92 & 118.81 & -0.35 & -62.24 \\
\hline $\mathrm{Nb}$ & 9.19 & 11.34 & 1.21 & 11.15 & 8.30 & -0.14 & -1.29 \\
\hline Mo & 2.50 & 24.13 & 16.34 & 40.78 & 14.62 & 4.58 & 11.43 \\
\hline Sn & 1.41 & 3.76 & 3.79 & 5.33 & 4.06 & 1.75 & 2.46 \\
\hline $\mathrm{Sb}$ & 3.08 & 3.10 & 0.81 & 2.48 & 4.26 & 0.32 & 0.97 \\
\hline $\mathrm{Te}$ & 1.63 & 2.68 & 1.95 & 3.18 & b.d. & - & - \\
\hline Cs & 0.77 & b.d. & - & - & 0.06 & -0.93 & -0.72 \\
\hline $\mathrm{Ba}$ & 1835.38 & 1628.34 & 0.59 & 1085.43 & 1003.29 & -0.48 & -879.98 \\
\hline $\mathrm{La}$ & 38.28 & 122.53 & 4.74 & 181.50 & 115.82 & 1.88 & 72.01 \\
\hline $\mathrm{Ce}$ & 78.16 & 188.39 & 3.32 & 259.76 & 211.81 & 1.58 & 123.54 \\
\hline $\mathrm{Pr}$ & 8.97 & 16.69 & 2.34 & 20.96 & 19.57 & 1.08 & 9.67 \\
\hline $\mathrm{Nd}$ & 35.11 & 51.44 & 1.63 & 57.15 & 60.11 & 0.63 & 22.13 \\
\hline $\mathrm{Sm}$ & 6.01 & 5.25 & 0.57 & 3.41 & 6.79 & 0.08 & 0.46 \\
\hline $\mathrm{Eu}$ & 1.63 & 2.68 & 1.96 & 3.19 & 2.89 & 0.69 & 1.12 \\
\hline Gd & 4.60 & 4.66 & 0.82 & 3.77 & 5.27 & 0.09 & 0.42 \\
\hline $\mathrm{Tb}$ & 0.75 & 0.63 & 0.50 & 0.38 & 0.67 & -0.16 & -0.12 \\
\hline Dy & 4.02 & 3.36 & 0.50 & 1.99 & 3.88 & -0.08 & -0.33 \\
\hline Но & 0.92 & 0.76 & 0.47 & 0.43 & 0.61 & -0.37 & -0.34 \\
\hline $\mathrm{Er}$ & 2.52 & 2.01 & 0.43 & 1.09 & 1.97 & -0.26 & -0.64 \\
\hline $\mathrm{Tm}$ & 0.33 & 0.37 & 0.98 & 0.33 & 0.29 & -0.16 & -0.05 \\
\hline $\mathrm{Yb}$ & 2.40 & 2.44 & 0.83 & 1.99 & 1.38 & -0.45 & -1.08 \\
\hline $\mathrm{Lu}$ & 0.32 & 0.30 & 0.68 & 0.22 & 0.20 & -0.41 & -0.13 \\
\hline $\mathrm{Hf}$ & 4.30 & 5.79 & 1.41 & 6.07 & 3.55 & -0.21 & -0.92 \\
\hline $\mathrm{Ta}$ & 0.64 & 0.67 & 0.89 & 0.57 & 0.64 & -0.04 & -0.03 \\
\hline $\mathrm{W}$ & 0.47 & 2.90 & 9.99 & 4.73 & 10.04 & 19.18 & 9.09 \\
\hline $\mathrm{Tl}$ & 0.53 & 0.14 & -0.52 & -0.28 & b.d. & - & - \\
\hline $\mathrm{Pb}$ & 8.87 & 10.46 & 1.12 & 9.89 & 11.83 & 0.27 & 2.39 \\
\hline $\mathrm{Bi}$ & 0.06 & 0.93 & 25.16 & 1.61 & 1.90 & 27.34 & 1.74 \\
\hline Th & 6.89 & 12.72 & 2.31 & 15.93 & 11.46 & 0.58 & 4.02 \\
\hline $\mathrm{U}$ & 0.94 & 5.04 & 8.62 & 8.10 & 7.74 & 6.84 & 6.43 \\
\hline
\end{tabular}



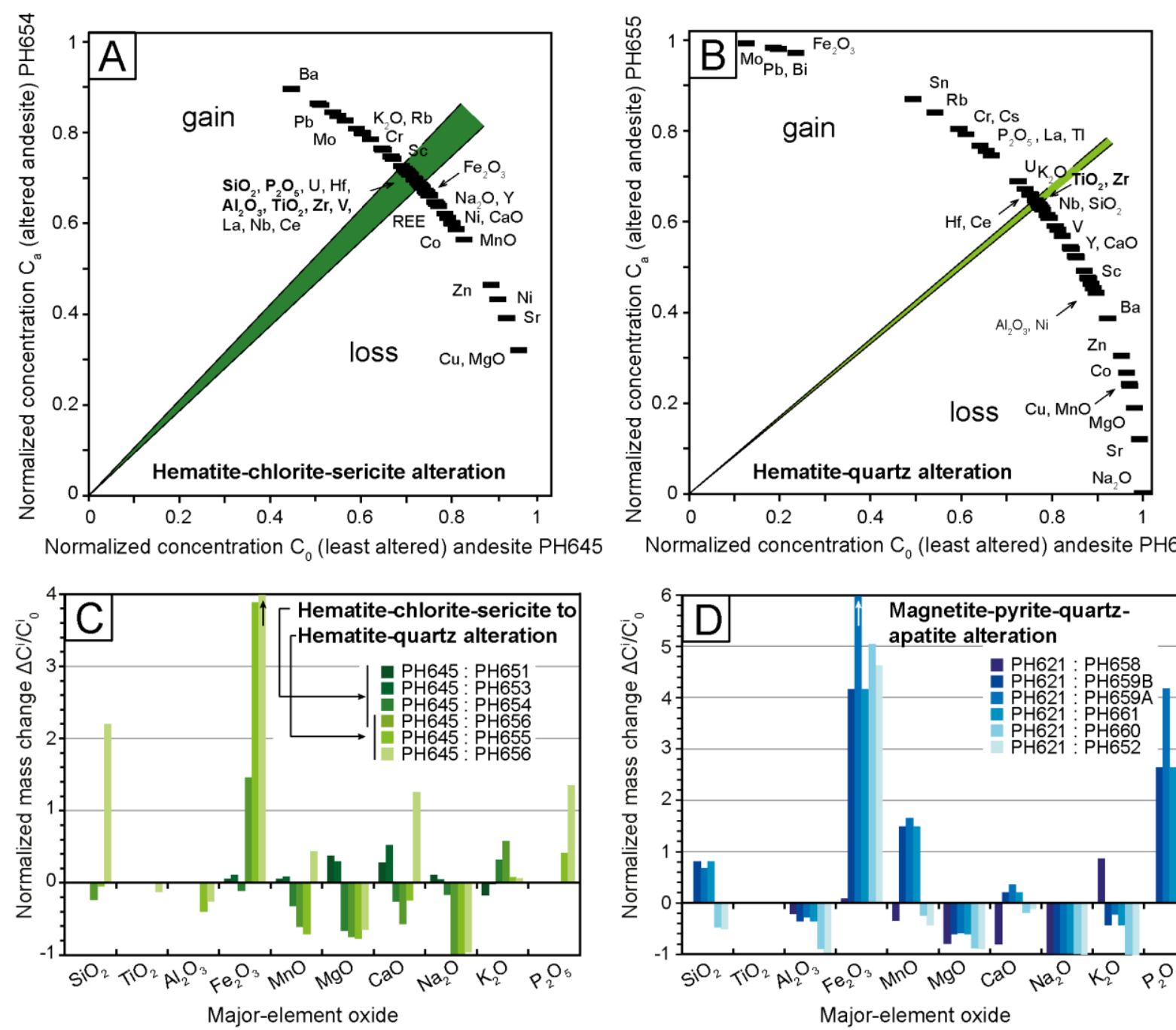

Normalized concentration $\mathrm{C}_{0}$ (least altered) andesite PH645
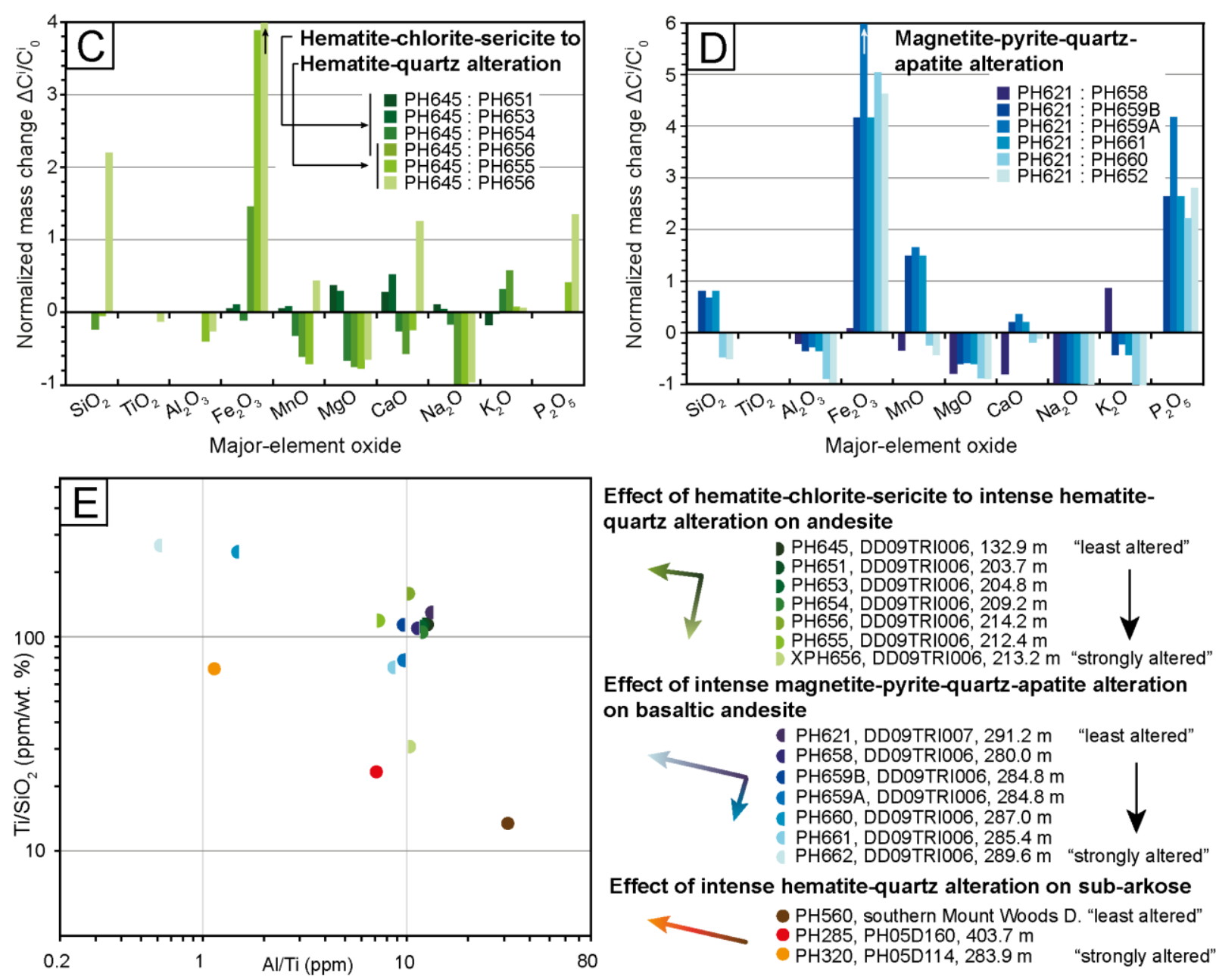

Effect of hematite-chlorite-sericite to intense hematitequartz alteration on andesite

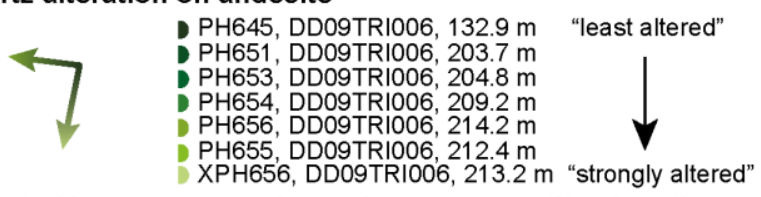

Effect of intense magnetite-pyrite-quartz-apatite alteration on basaltic andesite

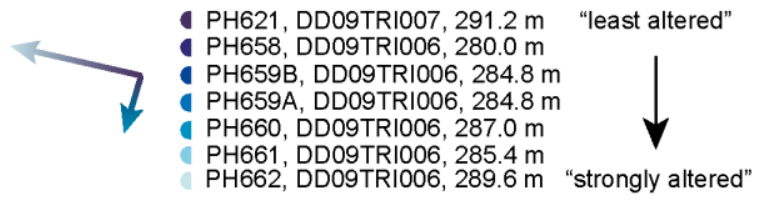

Effect of intense hematite-quartz alteration on sub-arkose

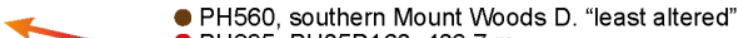
- PH285, PH05D160, $403.7 \mathrm{~m}$ PH320, PH05D114, $283.9 \mathrm{~m} \quad$ "strongly altered"

Fig. 14. Sample-scale alteration mass balance based on whole-rock XRF and LA-ICPMS data of adjacent drill core samples. Rescaled concentration data for (A) hematite-chlorite-sericite alteration and (B) hematite-quartz alteration allow identification of most conservative elements (bold), using method of Humphris et al. (1998). (C, D) Results for hematitechlorite-sericite to hematite-quartz alteration (Fig. 3) and magnetite-pyrite \pm quartz alteration of mafic volcanic rocks from the Triton prospect. (E) Al-Ti-SiO 2 plot showing effects for iron oxide-bearing alteration compared to those for least-altered reference samples (see text for discussion). 
The variation in ratios of least-mobile elements is summarized using an $\mathrm{Al} / \mathrm{Ti}$ vs. $\mathrm{Ti} / \mathrm{SiO}_{2}$ diagram (Fig. 14E). This plot confirms that the effect of hematite-chlorite-sericite to weak hematite-quartz alteration, compared to the least-altered andesites, is negligible. However, significant variations occur during local and intense hematite-quartz- and magnetite-quartz alteration leading to significantly lower $\mathrm{Al} / \mathrm{Ti}$ ratios and slightly variable $\mathrm{Ti} / \mathrm{SiO}_{2}$ ratios due to $\mathrm{Al}$ loss and $\mathrm{SiO}_{2}$ mobility. Intense hematite-quartz alteration of the sub-arkose is characterized by a decrease in the Al/Ti ratio by a factor $\sim 30$ if we assume that the precursor sandstone had a similar Ti concentration as the hematitequartz-altered sandstone. Even if the altered sandstone (PH320; Fig. 13E) was originally a quartz arenite, instead of the sub-arkose (PH560; Fig. 14E), the Al/Ti ratio would be lower by a factor between 4 and 12 when compared to average quartz arenites having $\mathrm{Al} / \mathrm{Ti}$ ratios between $\sim 4$ and $\sim 13$ (Pettijohn et al., 1987). Comparing the dispersion of volcanic and sedimentary rocks samples in the $\mathrm{Al}-\mathrm{Ti}-\mathrm{SiO}_{2}$ ratio diagram (Fig. 14E) with the variability of assay data for volcanic and sedimentary rocks (Fig. 15A) indicates that the least-mobile element ratios can be used to establish a model for the primary lithology distribution prior to hematite alteration. However, lithochemical interpretation of unaltered host rocks is only possible for sample intervals that show hematite-chlorite-sericite to weak hematite-quartz alteration, because the $\mathrm{Al}$ and $\mathrm{Si}$ were mobile during intense hematite-quartz alteration.

\subsection{Chemical lithology model}

Protolith recognition by core logging is most reliable distal from the most intense magnetite- and hematite-dominant alteration zones, based on preserved macroscopic textures. Even in most intensely altered breccias, the distinction of clast protolith between fine-grained and equigranular sedimentary rocks and phenocryst-bearing magmatic rocks is possible, regardless of whether the precise type of sediment or igneous rock can no longer be determined visually. We therefore have assumed that each host rock interval logged by company geologists was correctly assigned to either a sedimentary or magmatic protolith, including massive dolostones and equigranular or very crystalrich intrusive rocks. Logging data from five cross sections (coordinates in mine grid, UTM Zone 53 with easting reduced by 500000), matched with their assay data, were loaded into ioGAS software. As a first-order division of lithologies, drill core intervals logged as dolostone or intrusive rock were considered separately from the other sedimentary and magmatic rocks. Thus, drill core intervals were divided into four host rock units, specifically (a) siliciclastic rocks including carbonate-bearing varieties (cf. Fig. 6); (b) dolostones; (c) volcanic rocks including (sub-volcanic) sills and dikes; and (d) intrusive rocks; a fifth unit represents the hematite breccia body with logged intervals of hematitealuminosilicate breccia and hematite-quartz breccia. These rock units form distinct but partly overlapping data clusters in diagrams that plot ratios for least-mobile elements (Fig. 15A-F; Table 3 in Appendix).

\subsection{Assay data distribution in the $\mathrm{Al} / \mathrm{Ti}-\mathrm{Ti} / \mathrm{SiO}_{2}$ diagram}

Sedimentary rocks show generally lower $\mathrm{Ti} / \mathrm{SiO}_{2}$ ratios compared to volcanic host rocks (Fig. 15A-D). Siliciclastic rocks display a largely bimodal distribution (Fig. 15B). The majority have high $\mathrm{Al} / \mathrm{Ti}$ ratios and form distinct data cluster S1, separated from a smaller population termed S2. At higher $\mathrm{Ti} / \mathrm{SiO}_{2}$ ratios (S3), the compositional distribution of siliciclastic rocks overlaps with those of the volcanic rocks. A distinct data concentration with significantly lower Al/Ti ratios plots as diffuse cluster S4; These are separated from higher Al/Ti ratio-bearing siliciclastic rocks by a linear data field showing increasing Al/Ti ratios (Fig. 15B). The dolostone is a rigid rock unit (Fig. 15C) and is logged most reliably. Most data for the volcanic unit form a narrow, elliptical distribution around clusters V1 and V2 (Fig. 15D). Accumulations of data having lower density occur in clusters V3 and V4, and in a weak accumulation in V5 with significantly lower $\mathrm{Al} / \mathrm{Ti}$ ratios. The data distribution of logged 
intrusive rock intervals (Fig. 15E) shows distinct clusters consistent with logged lithologies. The dense data population of the hematite breccia body (Fig. 15F) essentially matches those of clusters S1 and S2 and delineates the linear data field that extends towards cluster S4. Comparison of data from the hematite breccia body and the host rocks shows that the majority of the breccias coincide with the data distribution for the siliciclastic rocks (Fig. 15G).
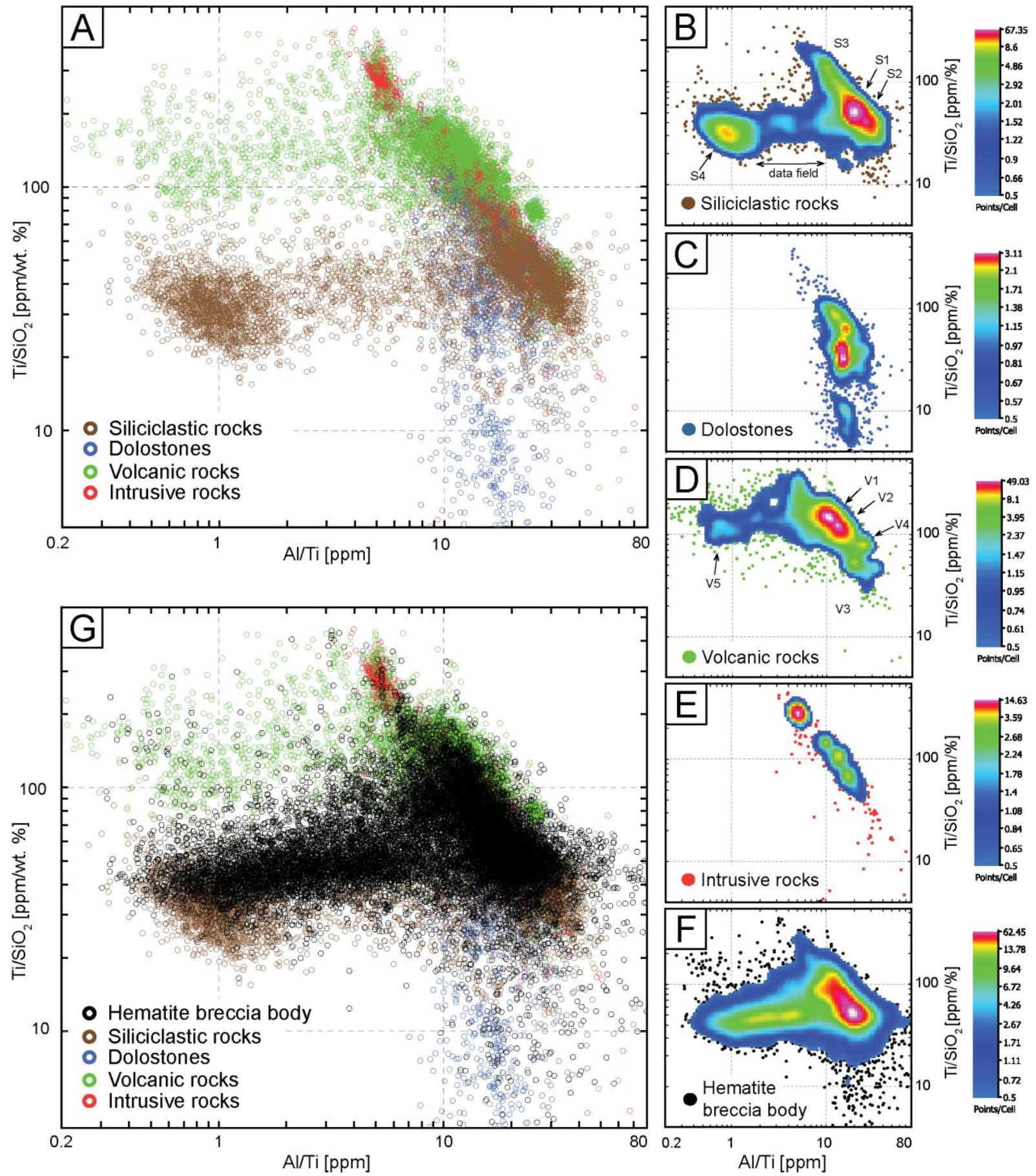

Fig. 15. Combined assay data for five exploration sections visualizing (A) logged dill hole intervals grouped according to main rock types. (B-E) Diagrams showing data density distribution of individual subunits including (F) hematite breccia body. Diagrams for each subunit identify data clusters. (G) Composition of hematite breccia body intervals superimposed on those of main rock units; note majority of the hematite breccia body coincides with data for sedimentary host rock sequence. 
Table 3. Clustered data for volcanic and sedimentary rocks at Prominent Hill.

\begin{tabular}{lccc}
\hline \hline Subunit (abundance) & Data cluster & Data density high in: \\
\hline \hline Volcanic rocks (22 \%) & \multicolumn{4}{c}{$\mathrm{Al} / \mathrm{Ti}[\mathrm{ppm}]$} & $\mathrm{Ti} / \mathrm{SiO}_{2}$ [ppm/wt. \%] \\
& $\mathrm{V} 1$ & 10 & 154 \\
& $\mathrm{~V} 2$ & 14 & 114 \\
& $\mathrm{~V} 3$ & 20 & 52 \\
& $\mathrm{~V} 4$ & 25 & 81 \\
& $\mathrm{~V} 5$ & 0.8 & 117 \\
\hline Siliciclastic rocks (29\%) & $\mathrm{S} 1$ & 20 & 51 \\
& $\mathrm{~S} 2$ & 28 & 42 \\
& $\mathrm{~S} 3$ & - & 30 \\
\hline Dolostone (4 \%) & $\mathrm{S} 4$ & 0.85 & 50 \\
\hline Intrusive rock (4 \%) & \multicolumn{3}{c}{ logged intervals used for lithochemical model } \\
\hline Hematite breccias (41 \%) & \multicolumn{3}{c}{ logged intervals used for lithochemical model } \\
\hline
\end{tabular}

\subsection{Subdivision of siliciclastic, volcanic, and intrusive rocks based on Al-Ti- Si ratios}

By plotting numerous multi-component diagrams among the elements found to be least mobile based on small-scale mass-balance studies (Fig. 14), we evaluated the geochemical data from the mine area and compared these with data for regional sedimentary and volcanic reference samples. This approach allowed the subdivision of all siliciclastic sedimentary rocks and volcanic rocks from the deposit according to distinct data clusters observed in plots of ratios for least-mobile elements (Fig. 16). The attribution of these chemical groups to specific sedimentary or igneous protoliths is difficult-not least owing to effects from the mechanical mixing of different rock types within the breccias. Nevertheless, most data clusters are indicative of one dominant lithology, or group of lithologies. Data clusters and density minima among clusters were identified by $\mathrm{Al} / \mathrm{Ti}$ and $\mathrm{Ti} / \mathrm{SiO}_{2}$ frequency distribution analysis; these minima were used to define the rock classification boundaries shown in Figure 16.

Subdivision of siliciclastic rocks: Many of the regional siliciclastic rocks show the same leastmobile element ratios as those at Prominent Hill and act as reference samples for the classification scheme (Fig. 16A). However, it was not possible to differentiate individual siliciclastic rocks from Prominent Hill. Instead, these were considered as a group for interpretation and delineation of mappable lithological units (Fig. 16A).

Data cluster S1 coincides compositionally with varieties of carbonate-argillite breccias, graywacke, and argillite reference samples. For cluster S2, the majority of rocks are logged as sandstone. The $\mathrm{Al} / \mathrm{Ti}$ ratio of the sub-arkose reference sample overlaps with that in cluster $\mathrm{S} 2$, but the reference sample has a lower $\mathrm{Ti} / \mathrm{SiO}_{2}$ ratio that may reflect diverse Ti detrital sources for regional and local sandstone samples. The chlorite-bearing limestone reference rock shows similar $\mathrm{Al}-\mathrm{Ti}_{-}-\mathrm{SiO}_{2}$ ratios as the sub-arkose. However, limestone was only recorded locally in the hematite breccia body, thus cluster S2 is interpreted to represent predominantly sandstone, possibly including some impure limestone. Due to the compositional similarity with volcanic rocks, subunit S3 may represent intervals of volcaniclastic rocks; these are, however, termed "sedimentary rock (high $\mathrm{Ti} / \mathrm{SiO}_{2}$ )." Drill core intervals recorded in cluster $\mathrm{S} 4$ have $\mathrm{Al} / \mathrm{Ti}$ ratios $\sim 1$ and low $\mathrm{Al}$ contents between $\sim 0.2$ and $\sim 0.4$ wt $\%$. For comparison, quartz-arenites show average Al/Ti ratios between $\sim 4$ and $\sim 13$ and average $\mathrm{Al}$ and Ti contents of 0.6 and $0.1 \mathrm{wt} \%$ (Pettijohn et al., 1987). Similar to hematite-quartz-altered sandstone reference samples (Fig. 14E), the data in cluster S4 represent intense hematite-quartz- 
altered and Al-depleted siliciclastic rocks in clusters S1-3 and not a specific lithology. Rocks represented in cluster S4 are termed "hematite-quartz rock (sedimentary protolith)."

Subdivision of volcanic rocks: Within the volcanic rock group, five lithologies were determined (Fig. 16B). The bulk of the volcanic rocks approximate (a) least-altered reference samples from the southern Mount Woods domain, and (b) average compositions of lower GRV as summarized in Blissett et al. (1993). Clusters V1 to V4 correspond to a series of basaltic to intermediate-composition volcanic rocks (Fig. 16B). Many of the rocks represented in cluster V5 contain $<0.5 \mathrm{wt} \% \mathrm{Al}$, but mostly high $\mathrm{Fe}$ contents $>25 \mathrm{wt} \%$. In addition, data for cluster V5 plot in the area where intense iron oxide \pm quartz alteration resulted in Al depletion (Fig. 14E). Volcanic rocks in cluster V5 are simply termed "hematite-quartz rock (volcanic protolith)."

Subdivision of intrusive rocks: Intrusive rocks were not further classified. Logged intrusive rocks include quartz microdiorite and quartz-diorite, and herein are simply classified as quartz diorite. Logged granite and tonalite are grouped collectively as granitoids.
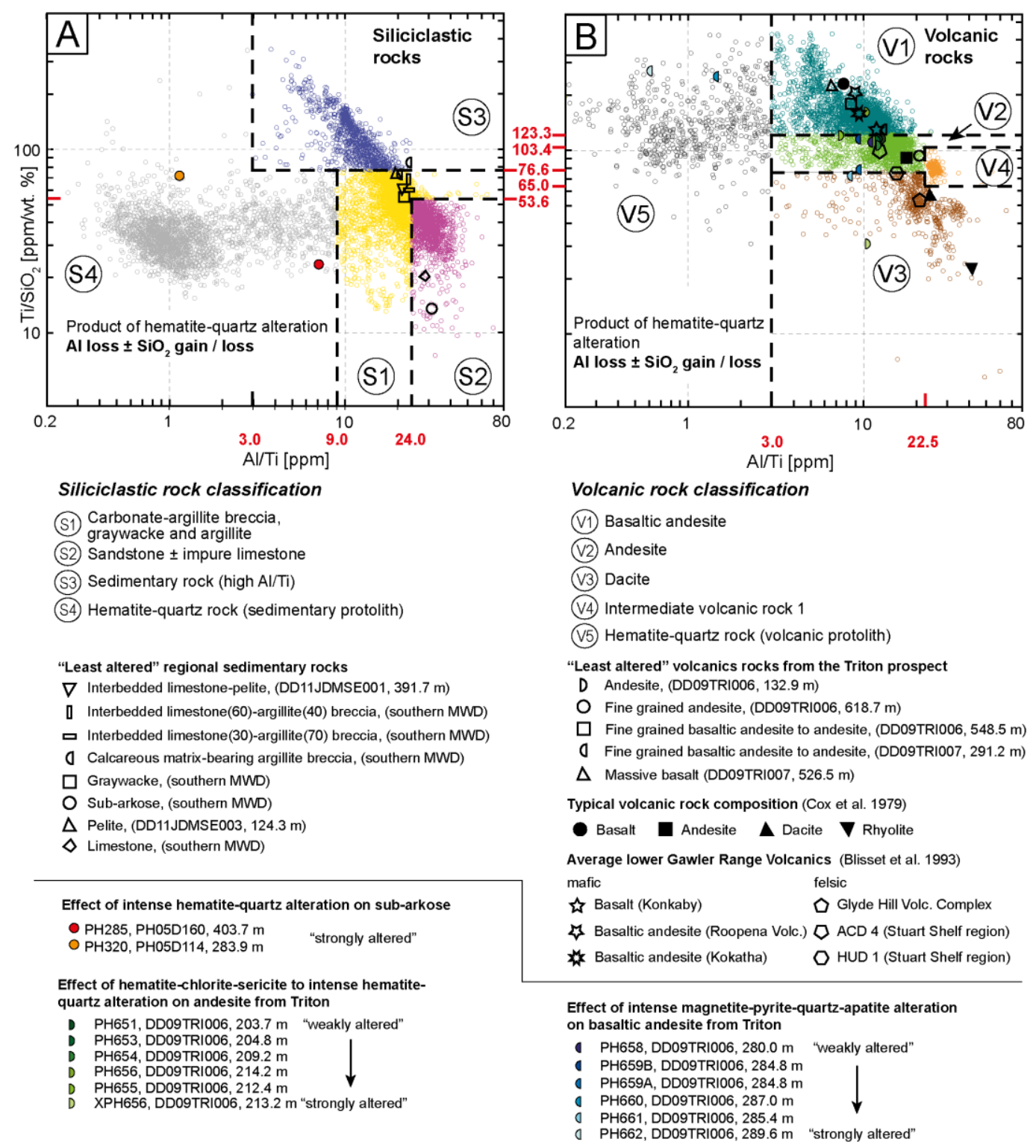

Fig. 16. Classification of (A) siliciclastic and (B) volcanic host rocks in to mappable chemical lithology groups according to $\mathrm{Al}-\mathrm{Ti}_{-} \mathrm{SiO}_{2}$ subdivisions. Compositions of various least-altered and altered local, regional, and typical rocks are given for reference. MWD, Mount Woods Domain. 


\subsection{Towards a three-dimensional lithochemical model for Prominent Hill}

The lithochemical model for Prominent Hill (Fig. 17) is an interpretation of the extent and geometry of geologically logged and chemically classified sedimentary, magmatic, and strongly iron oxide-quartz-altered rocks (Fig. 16). This interpretation is based on correlations between drill core intervals that contain the host rock lithologies and the hematite breccia body having the same Al-Ti$\mathrm{SiO}_{2}$ signature. It was guided by the lithochemical subdivision defined in Figures 15 and 16, supplemented by our core observations and by company logging that help to define some of the tentative boundaries. Reconstructions were made for three sections (see Appendix for details), which were subsequently assembled onto a perspective grid, thus maximizing the visibility of geological information.

Because the host rocks have overlapping $\mathrm{Al}-\mathrm{Ti}_{-} \mathrm{SiO}_{2}$ ratios (Fig. 15), some intervals of hematitealuminosilicate breccia could be classified as having either a sedimentary or a volcanic precursor. Wherever host rocks are in contact with intervals of hematite-aluminosilicate breccia, the breccia is typically correlated to the adjacent siliciclastic or volcanic rock neighbor, unless $\mathrm{Al}-\mathrm{Ti}^{-\mathrm{SiO}_{2}}$ ratios indicate a lithologic change. For the scale of reconstruction, a change of lithology has to be consistent over several meters to tens of meters. Many of the altered mafic sills and dikes could not be traced between adjacent drill holes, or the reconstruction resolution precluded their inclusion. To avoid discrimination in the reconstructions, green stars are used to mark locations of sills and dikes that occur in drill core (Fig. 17). At the structural base of the sedimentary host rock package, volcanic units begin to dominate, hence correlation between hematite breccia and volcanic rocks is considered appropriate.

Based on $\mathrm{Al}-\mathrm{Ti}-\mathrm{SiO}_{2}$ ratios, spatial vicinity, local logging indications, and petrography, the hematite breccias are mainly derived from sedimentary protoliths. Figure 17 shows an approximately elliptical shaped zone of hematite-quartz rocks that extend from the Permian erosion surface to depths below $9200 \mathrm{mRL}$ (meter relative level) and plunging steeply to the ENE (Fig. 17). Hematitequartz-altered rocks having a likely volcanic protolith occur at the contact between the sedimentary host rock package and structurally underlying volcanic rocks. The bulk of the hematitealuminosilicate breccia formed within carbonate-argillite breccias, graywacke, argillite, and sandstone. These siliciclastic rocks are locally intercalated with minor volcaniclastic material showing high $\mathrm{Ti} / \mathrm{SiO}_{2}$ ratios and with andesitic volcanic rocks with overlapping compositions (Fig. 17). We conclude from this lithogeochemical study that much of the $\mathrm{Cu}$ mineralized hematite breccia body formed from alteration of immature (i.e., feldspathic) and variably carbonate-bearing siliciclastic sedimentary rocks with a significant volcanic component. Lithochemical mapping also indicates that brecciation and mineralization formed essentially in situ without major mechanical mixing of breccia components.

\section{Correlations Between Hydrothermal Alteration and $\mathrm{Cu}$ Mineralization}

Hydrothermal modifications of the rock package shown in Figure 17 were mapped by concentration ratios including elements that were clearly mobile, i.e., $\mathrm{Fe}, \mathrm{Cu}, \mathrm{Na}$, $\mathrm{K}$, and $\mathrm{Ca}$ (Figs. 1821). We express concentrations of these mobile elements in molar units, in order to facilitate their interpretation in terms of major mineralogical changes associated with hydrothermal alteration and mineralization.

\subsection{The hematite-quartz alteration index (HMSI-value)}

The hematite-quartz alteration index (HMSI), defined as the molar $(\mathrm{Fe}+\mathrm{Si}) /(\mathrm{Fe}+\mathrm{Si}+\mathrm{Al})$ ratio, was found to be a useful measure for the degree of this type of alteration. High HMSI values indeed 


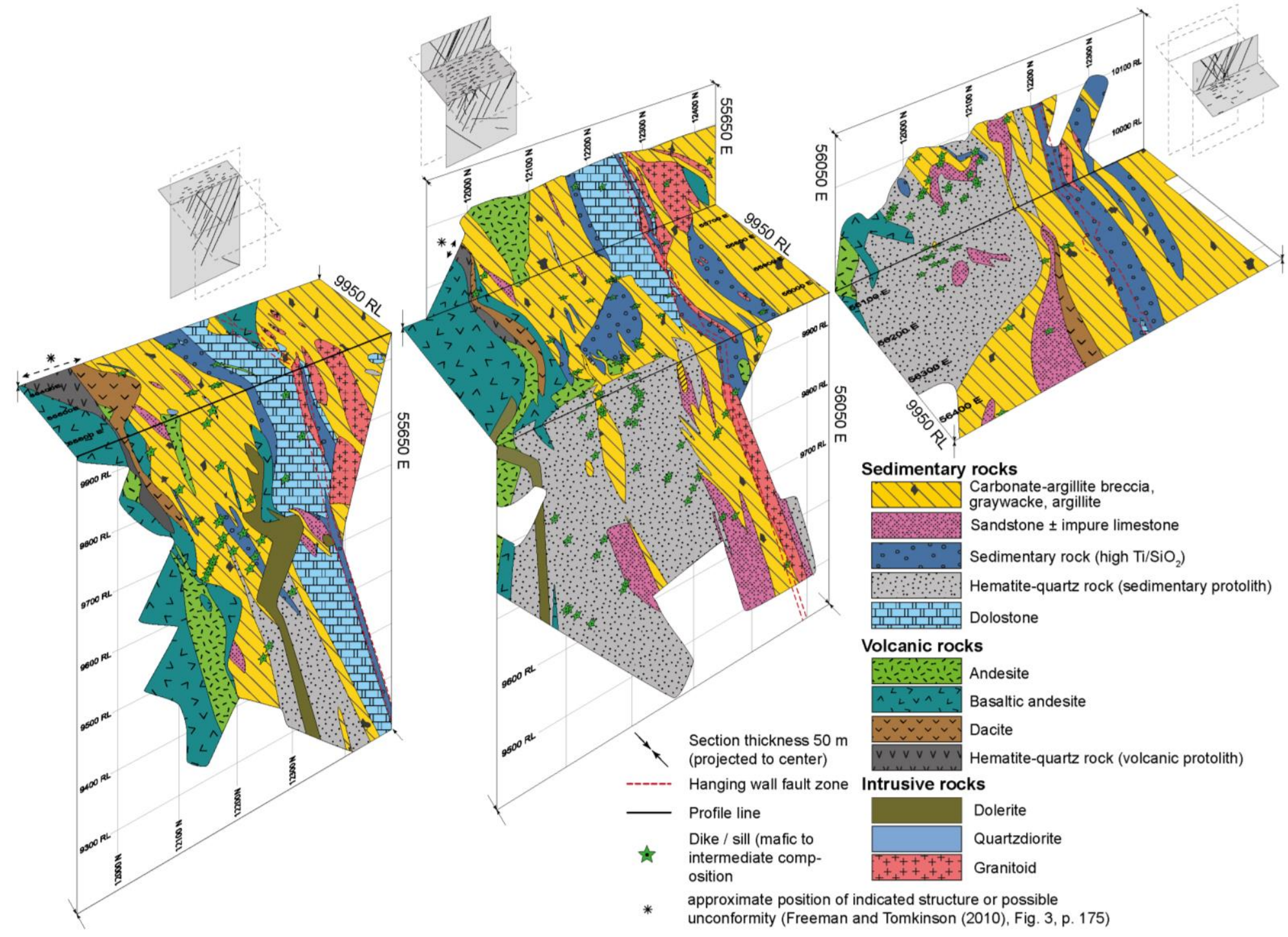

Fig. 17. Interpreted distribution of Prominent Hill host rocks outside zones of intense hematite-quartz alteration. Reconstructions are based on distribution of Al-Ti-SiO 2 ratios and chemical rock classification provided in Figure 16. Gray icons next to the colored sections indicate drill core density for each section and allow separation between areas having higher confidence from areas with lower confidence. All coordinates are in the mine grid, UTM Zone 53 with easting reduced by 500000. 
correspond to logged intervals of hematite-quartz breccia. Low HMSI values more likely reflect hematite-aluminosilicate breccia and weakly altered host rock (Fig. 18A). By comparing logged hematite breccia types with each other in a cumulative frequency diagram (Fig. 18B), the hematitequartz breccia intervals show the greatest probability for high HMSI values. The inflection at HMSI $\sim 0.975$ (Fig. 18B) separates the hematite-aluminosilicate breccia from the hematite-quartz breccia, and is interpreted to mark the transition between the two alteration types.
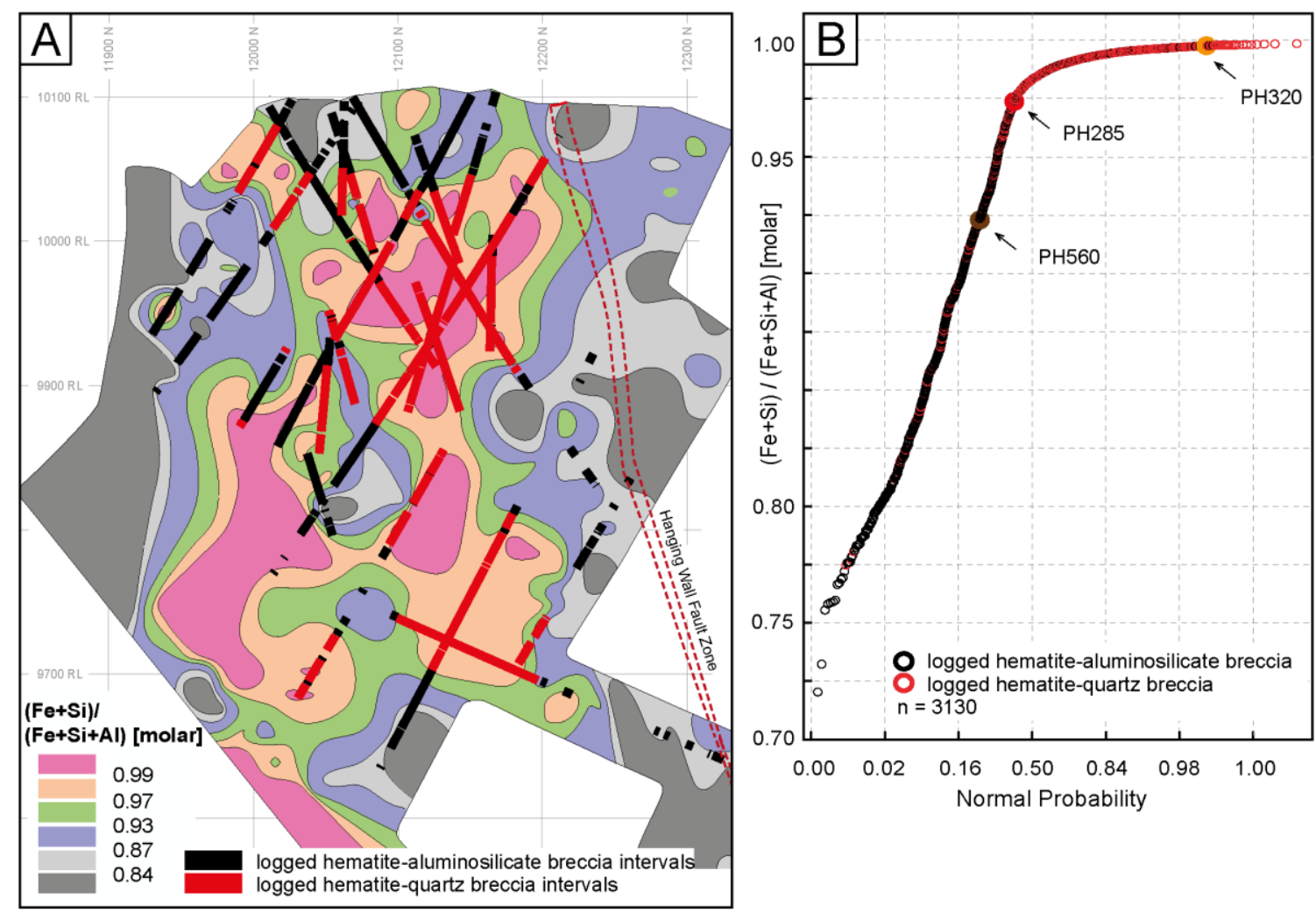

Fig. 18. (A) Cross section at $56050 \mathrm{mE} \pm 25 \mathrm{~m}$ showing logged intervals of hematite-aluminosilicate breccia (black) and hematite-quartz breccia (red) superimposed on distribution of molar $(\mathrm{Fe}+\mathrm{Si}) /(\mathrm{Fe}+\mathrm{Si}+\mathrm{Al})$ ratios (HMSI values). HMSI value accurately maps gradients in variable intensity of hematite-quartz alteration. (B) Diagram showing normal probability vs. molar HMSI value of logged hematite-aluminosilicate breccia and hematite-quartz breccia, in combination with data for sedimentary reference samples used in Figure 14E. Hematite-quartz breccia intervals show distinctively higher HMSI value probabilities.

\subsection{Relationships among $\mathrm{Cu}$ grade, hematite-quartz, and hematite- chlorite-sericite alteration}

High-grade $\mathrm{Cu}$ mineralization at Prominent Hill (>1 wt \%) occurs mainly in the hematitealuminosilicate breccia subtype and to some extent in less-altered host rocks. Copper grades show a positive correlation with whole-rock molar $\mathrm{K} / \mathrm{Al}$ values, ranging from that of the muscovite endmember $\left(\mathrm{KAl}_{3} \mathrm{Si}_{3} \mathrm{O}_{10}(\mathrm{OH})_{2}\right.$ with $\mathrm{K} / \mathrm{Al}=0.33$ ) to that of phengite solid solution (K/Al up to $\sim 0.38$; Fig. 19). This correlation is independent of the lithological subunit (Fig. 19) and overlaps with the range of white mica compositions found in Cu ores at Olympic Dam (Roberts and Hudson, 1983; Tappert et al., 2013). In general, intervals at Prominent Hill affected by intense hematite-quartz alteration (high HMSI values) show lower molar K/Al ratios, mainly below 0.28 (Fig. 19). 

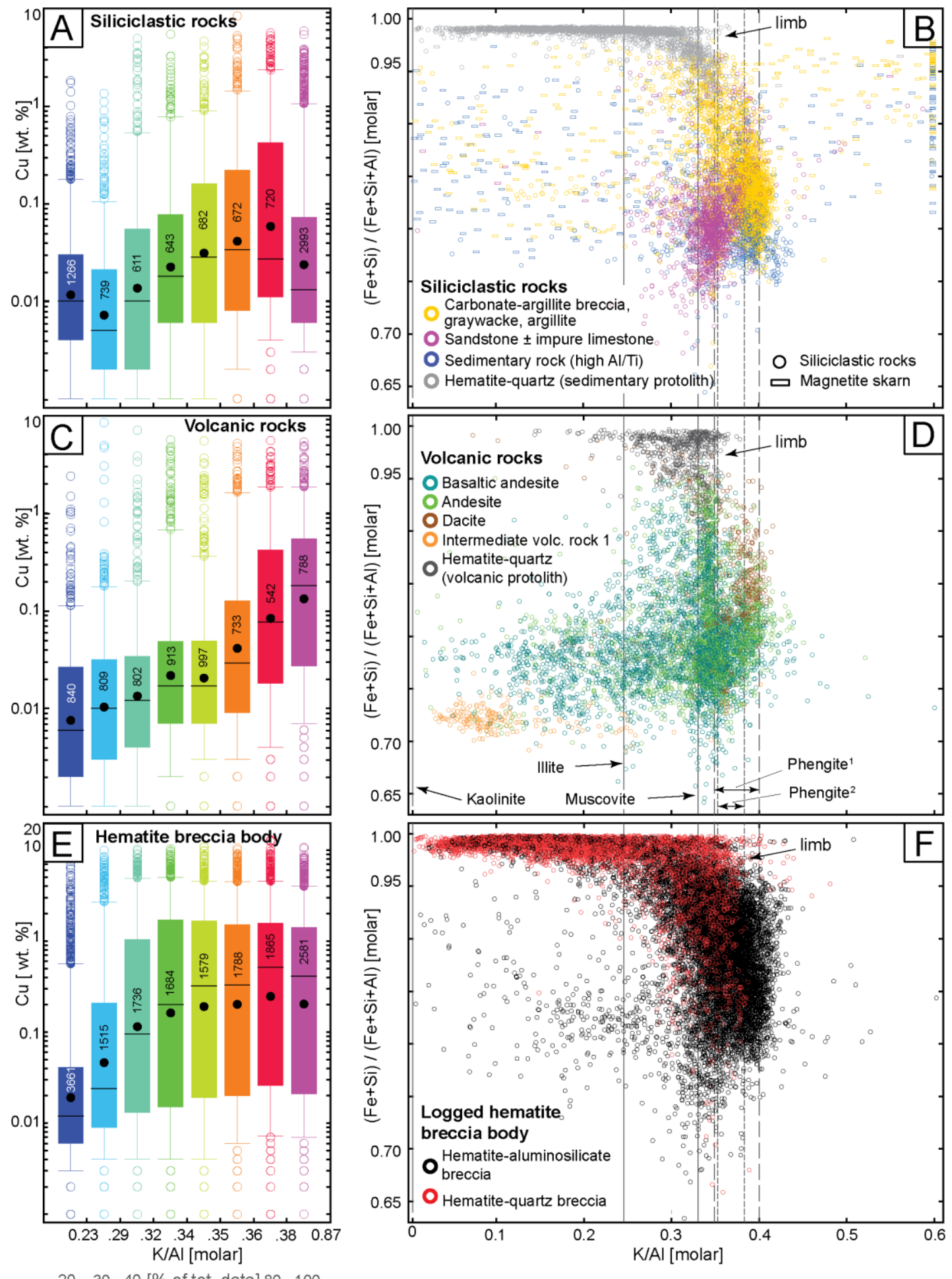

Fig. 19. Relationships among chemical lithology groups, $\mathrm{Cu}$ grade, and alteration at Prominent Hill. (Left column) Percentile box plots colored after molar $\mathrm{K} / \mathrm{Al}$ ratio indicating intensity of hematite-chlorite-sericite alteration. Black circle, mean; black line, median; central box, $50 \%$ of data from Q1 to Q3, whiskers represent $5 \%$ and $95 \%$ values; circle, outlier in bottom or top $5 \%$ of data. (Right column) Relationship between hematite-sericite-chlorite alteration indicated by molar $\mathrm{K} / \mathrm{Al}$ ratio vs. hematite-quartz alteration indicated by molar $(\mathrm{Fe}+\mathrm{Si}) /(\mathrm{Fe}+\mathrm{Si}+\mathrm{Al})$ ratio (HMSI value); vertical lines represent phengite; 1), range of phengite compositions in altered but Cu-barren Roxby Downs Granite from Olympic Dam (Tappert et al., 2013); 2), range of phengite compositions in Cu-mineralized hematite breccia from Olympic Dam (Roberts and Hudson, 1983; Tappert et al., 2013), illite point represents composition of $\mathrm{K}_{0.65} \mathrm{Al}_{2} \mathrm{Al}_{0.65} \mathrm{Si}_{3.5} 0_{10}(\mathrm{OH})_{2}$, kaolinite $\mathrm{Al}_{2} \mathrm{Si}_{2} \mathrm{O}_{5}(\mathrm{OH})_{2}(\mathrm{see} \mathrm{text} \mathrm{for}$ discussion). 
Siliciclastic rocks: The siliciclastic rocks show a correlation between Cu grades of $>0.01 \mathrm{wt} \%$ and molar K/Al values of 0.32 to 0.38 (Fig. 19A). A portion of the carbonate-argillite breccia, graywacke, argillite group, and the high $\mathrm{Al} / \mathrm{Ti}$ sedimentary rocks (groups S1 and S3; Fig. 16A) contain < $0.25 \mathrm{wt}$ $\% \mathrm{Cu}$ with HMSI values $<0.975$, but display higher $\mathrm{K} / \mathrm{Al}$ ratios up to 0.8. Data for these rock intervals project to a K/Al ratio of 0.6 (Fig. 19B). Many data points represent magnetite skarn intervals with likely phlogopite and preserved K-feldspar. The sandstone (S2; Fig. 16A) shows K/Al $\sim 0.34$ and is clearly offset from the data for the carbonate-argillite breccia, graywacke, and argillite group (Fig. 19B). Results for the carbonate-argillite breccia, graywacke, and argillite group as well as the sandstone show a trend between HMSI $\sim 0.77$ and 0.97 , whereas K/Al ratios remain constant or decrease slightly. In both lithologic groups, higher HMSI values are characterized by low $\mathrm{SiO}_{2}$ and high Fe contents. This inverse trend is anticipated when comparing it with results of alteration mass balance calculations for the weakest hematite-quartz alteration, which is characterized by $\mathrm{SiO}_{2}$ leaching and contemporaneous addition of iron oxide (Fig. 14B, C).

The bulk of the Al-poor hematite-quartz rock (sedimentary protolith) (S4; Fig. 16A) is equally distributed between molar K/Al ratios of 0.05 and 0.35 (Fig. 19B). Besides a few drill core intervals with $\mathrm{Cu}$ grade above $0.1 \mathrm{wt} \%$, this unit lacks a peak of higher $\mathrm{Cu}$ values linked to a specific $\mathrm{K} / \mathrm{Al}$ ratio. The highest HMSI values are close to unity, which is partly due to: (a) high $\mathrm{SiO}_{2}$ contents, mostly between 60 to 85 wt \% $\mathrm{SiO}_{2}$; (b) intermediate Fe contents commonly between 15 and $38 \mathrm{wt} \%$; and (c) the lowest $\mathrm{Al}$ contents of the entire data set. Much of the data in the limb grading from low K/Al values towards 0.33 (Fig. 19B) show Al/Ti ratios between $\sim 2$ and $\sim 9$ and appear in the abovementioned data field trending towards carbonate-argillite breccia, argillite, graywacke, and sandstone (Fig. 16B).

Volcanic rocks: The volcanic units are variably K-altered and have molar K/Al ratios up to 0.41 with $1 \%$ of the data showing ratios up to 0.63 (Fig. 19C, D). Unlike the sedimentary rocks, Cu grades $>0.01 \mathrm{wt} \%$ in the volcanic rocks correlate with high $\mathrm{K} / \mathrm{Al}$ ratios and display an increase above $\mathrm{K} / \mathrm{Al}$ $=0.35$ (Fig. 19C). The majority of basaltic andesite and andesite intervals (V1-2; Fig. 16B) plot at molar K/Al $\sim 0.35$ and HMSI $\sim 0.78$, showing broadly orthogonal trends towards lower K/Al ratios and higher HMSI values (Fig. 19D). Sixty percent of basaltic andesite and andesite samples have K/Al ratios between 0.32 and 0.41 , and low HMSI values between 0.73 and 0.92 excluding lower and upper $5 \%$ statistical outliers. These drill core intervals represent sericite-stable and weakly hematitequartz-altered volcanic rocks. Moreover, they show significantly higher $\mathrm{Cu}$ grades than the remaining $40 \%$ of the analyzed intervals, with $\mathrm{K} / \mathrm{Al}$ ratios below 0.32 . The dacite (V3; Fig. 16B) shows a trend of increasing Fe contents and a HMSI value of $\sim 0.97$ where the latter values approach 1 and $\mathrm{K} / \mathrm{Al}$ ratios decrease to <0.2 (Fig. 19D). Intermediate-composition volcanic rock 1 (V4; Fig. 16B) and some intervals of basaltic andesite and andesite show $\mathrm{K} / \mathrm{Al}<0.25$, low HMSI values $<0.9$ (Fig. 19D), molar $(2 \mathrm{Ca}+\mathrm{Na}+\mathrm{K}) / \mathrm{Al}$ between $\sim 0.8$ and $\sim 1.2$ (Warren et al., 2007), and molar $\mathrm{Na} / \mathrm{Al}$ ratios $>0.31$. These rocks are weakly sericite-altered and have typically low $\mathrm{Cu}$ contents $(<0.1 \mathrm{wt} \%)$. The other extreme is represented by the hematite-quartz rock having a volcanic protolith (V5; Fig. 16B), which has K/Al ratios of $\sim 0.25$ to 0.36 and HMSI values from $\sim 0.97$ to 0.99 (Fig. 19D). The unit displays the lowest $\mathrm{Cu}$ grades $(<0.01 \mathrm{wt} \%)$ of all volcanic rocks. Drill core intervals of the hematite-quartz rock (volcanic protolith) show intermediate to high $\mathrm{Fe}_{2} \mathrm{O}_{3}$ contents ( $\sim 20$ to $66 \mathrm{wt} \%$ ) with a large data population having 25 to $38 \mathrm{wt} \% \mathrm{Fe}$ and low $\mathrm{SiO}_{2}$ contents of 42 to $55 \mathrm{wt} \%$. In contrast to the hematite-quartz rock (volcanic protolith), the dacite contains abundant $\mathrm{Cu}$ (typically $>0.02 \mathrm{wt} \%$ ) and lower average HMSI values. Both units occur in the vicinity of the structural contact between the altered volcanic rocks and sedimentary host rocks (Fig. 17).

Hematite breccia body: Copper grades $>0.1 \mathrm{wt} \%$ within the hematite breccia body occur typically in rocks having molar $\mathrm{K} / \mathrm{Al}$ ratios between 0.32 and 0.41 (Fig. 19E). Only $2 \%$ of the data show higher ratios up to 0.60 . Below $\mathrm{K} / \mathrm{Al}=0.29, \mathrm{Cu}$ grades are significantly lower and logged hematite-quartz breccias predominate over hematite-aluminosilicate breccia (Fig. 19F). In turn, Cu grades $>0.5$ wt $\%$ in the hematite-aluminosilicate breccia are mostly accompanied by molar K/Al ratios of $\sim 0.3$ to 0.41 and show a broad peak between the K/Al ratio of muscovite and that of white mica, as determined 
for the Cu mineralized hematite-sericite breccia at Olympic Dam (Fig. 19F; Roberts and Hudson, 1983; Tappert et al., 2013).

Intensity of hematite-quartz alteration inversely correlates with Cu grade: Inspection of the entire dataset and of results for individual lithologic groups reveals an inverse correlation between the HMSI value and $\mathrm{Cu}$ grade probability. The probability of a specific $\mathrm{Cu}$ grade within a HMSI value range (or a geologic unit) to be less than a threshold is calculated by counting the number of samples below the threshold and dividing by the total number of samples (cf. Rossi and Deutsch, 2014 and references therein). High $\mathrm{Cu}$ grade probabilities correlate with low and intermediate HMSI values and appear to be partly independent of iron contents (Fig. 20A). For example, $\sim 50 \%$ of rock intervals with $0.83<$ HMSI $<0.98$ contain $\mathrm{Cu}>0.1 \mathrm{wt} \%$. In contrast, only $\sim 7 \%$ of intervals having HMSI values $>0.995$ contain $\mathrm{Cu}>0.1 \mathrm{wt} \%$ (Fig. 20A).
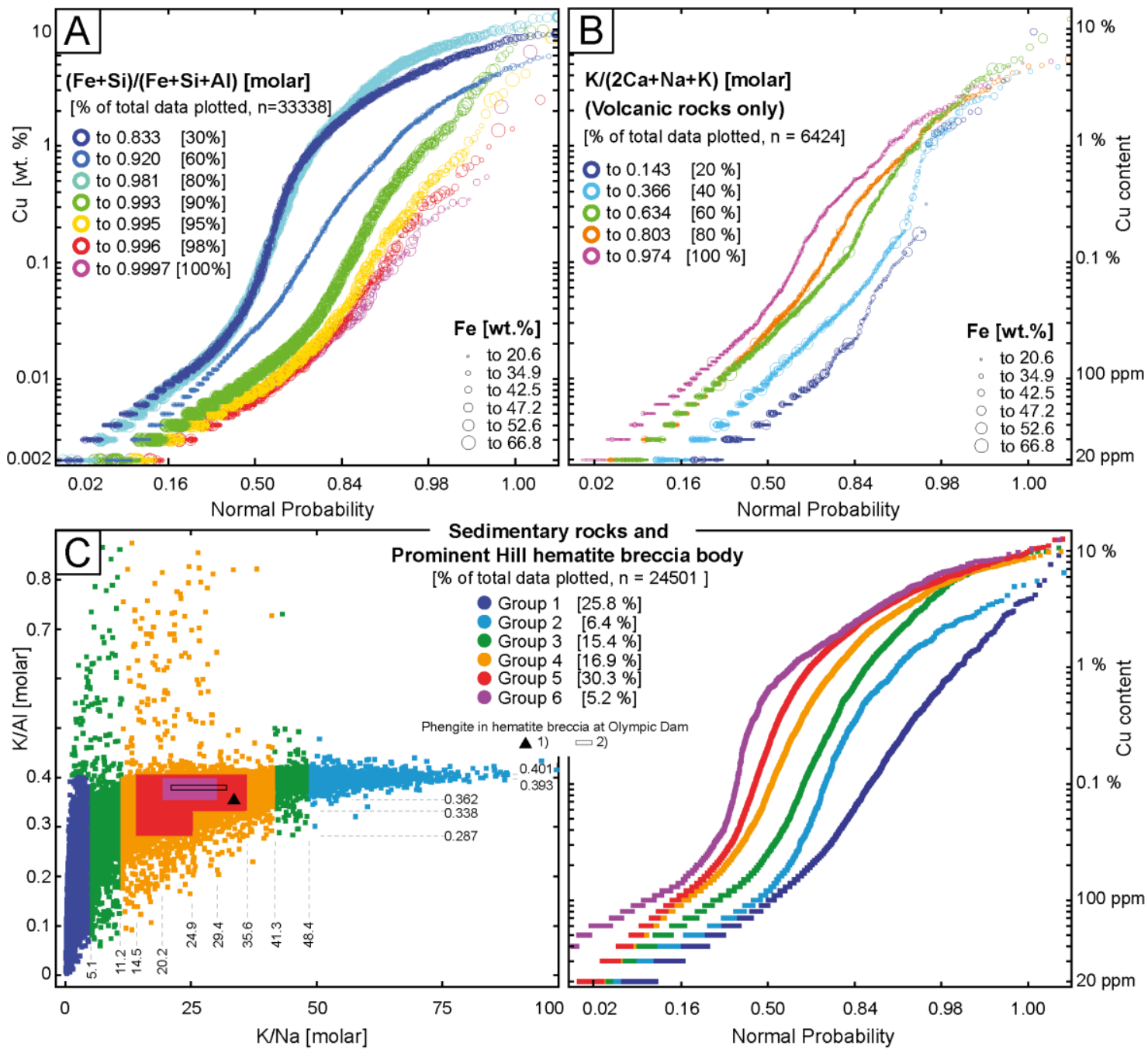

Fig. 20. Correlation between alteration and $\mathrm{Cu}$ mineralization at Prominent Hill. (A) Relationship between probability of Hematite Quartz Alteration Index (HMSI value) and Fe content vs. $\mathrm{Cu}$ grade in volcanic, sedimentary, intrusive rocks, and Prominent Hill hematite breccia body. (B) Split probability of molar K/(2Ca+Na+K) ratio of volcanic rocks indicating degree of K-metasomatism including Fe content vs. Cu grade. (C) Relationship between degree of K-metasomatism and Cu grade probability for altered sedimentary rocks and Prominent Hill hematite breccia body; (Left) Molar K/Na vs. K/Al alteration matrix; Groups 1-5 indicate areas maximized to $\mathrm{Cu}$ grade probability; 1), average phengite composition of $\mathrm{Cu}$-bearing hematite breccia from Olympic Dam (Roberts and Hudson, 1983); 2), compositional range of chalcocite and bornite-rich hematite breccia from Olympic Dam (Tappert et al., 2013). (Right) Blue area marks low Cu grade probability, purple area the highest (see text for discussion). 
Degree of alteration correlates with Cu grade: The degree of K-bearing alteration in volcanic rocks can be determined by use of the molar $\mathrm{K} /(2 \mathrm{Ca}+\mathrm{Na}+\mathrm{K})$ ratio (Warren et al., 2007). Volcanic rocks at Prominent Hill show a strong correlation between high $\mathrm{K} /(2 \mathrm{Ca}+\mathrm{Na}+\mathrm{K})$ ratios and anomalous to high $\mathrm{Cu}$ grade probability (Fig. 20B). For example, intervals having $\mathrm{K} /(2 \mathrm{Ca}+\mathrm{Na}+\mathrm{K})>0.97$ have a $90 \%$ probability for $\mathrm{Cu}$ contents of $>50 \mathrm{ppm}$ and a $\sim 40 \%$ probability for $\mathrm{Cu}>0.1$ wt \%. By contrast, intervals having $\mathrm{K} /(2 \mathrm{Ca}+\mathrm{Na}+\mathrm{K})<0.14$ show only a $\sim 50 \%$ probability for $\mathrm{Cu}>50 \mathrm{ppm}$. The probability rapidly decreases towards higher Cu contents, with only $7 \%$ of the data showing a Cu grade $>0.1 \%$, compared to a $\sim 45 \%$ probability for such grades occurring in the highly K-metasomatized volcanic rocks.

Relationships among degree of alteration, acid neutralization buffer capacity of the rock, and $\mathrm{Cu}$ grades in sedimentary host rocks and the hematite breccia body are indicated in Figure 20C. Maximizing the $\mathrm{Cu}$ grade probability indicates that the highest $\mathrm{Cu}$ probability is shown by whole-rock molar K/Al ratios between $\sim 0.3$ and $\sim 0.4$, in combination with $\mathrm{K} / \mathrm{Na}$ ratios between $\sim 20$ and $\sim 36$. Data points in group 1 have a $50 \%$ probability for $\mathrm{Cu}>100 \mathrm{ppm}$, whereas only $\sim 5 \%$ have $>0.6$ wt $\%$ $\mathrm{Cu}$. For comparison, data in group 6 have a $90 \%$ probability for $\mathrm{Cu}$ contents $>100 \mathrm{ppm}$; $50 \%$ of the data have $>0.6 \mathrm{wt} \% \mathrm{Cu}$.

\subsection{Footprints of alteration and mineralization superimposed on chemical lithologic geometry}

At Prominent Hill, $\mathrm{Cu}$ grades of $>0.1 \mathrm{wt} \%$ typically occur in zones of low to intermediate HMSI values (Figs. 20A, 21A), where molar $\mathrm{K} / \mathrm{Al}$ ratios indicate the presence of sericite rather than $\mathrm{K}$ feldspar (Fig. 21B) and molar K/Na ranges between $\sim 20$ and $~ 36$ (Fig. 21C). In terms of the spatial Fe distribution, high Fe contents generally do not correlate with areas of high Cu contents (Fig. 21D) or high HMSI values (Fig. 21A). The HMSI values show a patchy distribution, steep gradients, and do not mimic lithological units. The good spatial agreement between $\mathrm{Cu}$ grades and K/Al values (Fig. 21B) indicates that much of the feldspar in the volcanic host rocks was altered to sericite, or alternatively that sericite in sedimentary host rocks remained stable during alteration. The K/Na ratio distribution between 13.5 and 33.5 along section $56050 \mathrm{mE}$ (Fig. 21C) resembles that of the chemical groups of host lithologies interpreted to contain minerals (i.e., carbonate and feldspar) that have the ability to neutralize acidic hydrothermal fluids during fluid-rock interaction. Rocks that still possess this acid buffer capacity must have been unaffected by the intense hematite-quartz alteration. The distribution of $\mathrm{K} / \mathrm{Na}$ ratios further indicates that the highest $\mathrm{Cu}$ grades are not found where extreme Na depletion occurred (Fig. 21C), which is in agreement with the presence in these areas of weak to moderate hematite-quartz alteration.

\section{Interpretation and Discussion}

The $\mathrm{Cu}-\mathrm{Au}$ mineralized hematite breccia body at Prominent Hill is bounded by mostly unbrecciated, tabular sedimentary and volcanic host rocks. Hydrothermal alteration led to hematite pervasively replacing the calcareous and dolomitic matrix of breccias. Chemical corrosion and hydrothermal replacement of aluminosilicate-rich rock components resulted in the formation of hematite, sericite, siderite, sulfides, and quartz, together with minor amounts of fluorite, barite, ankerite, fluorapatite, and REE minerals (Figs. 8-10). Paragenetically late and cyclic $\mathrm{Cu}$-(Fe)-sulfide mineralization (Fig. 12) occurs in a discordant front of alteration and mineralization associated with low degrees of hematite-quartz alteration (Figs. 19-22) that show a predominance of hematite and sericite (Fig. 21). These findings support our interpretation that the intensity of hydrothermal alteration exerted a decisive chemical control on the local precipitation and mine-scale distribution of $\mathrm{Cu}$ mineralization. Figure 23 summarizes the evolution of sedimentary and volcanic host-rock deposition, fault-related deformation, and hydrothermal alteration that led to formation of the Prominent Hill IOCG deposit. 


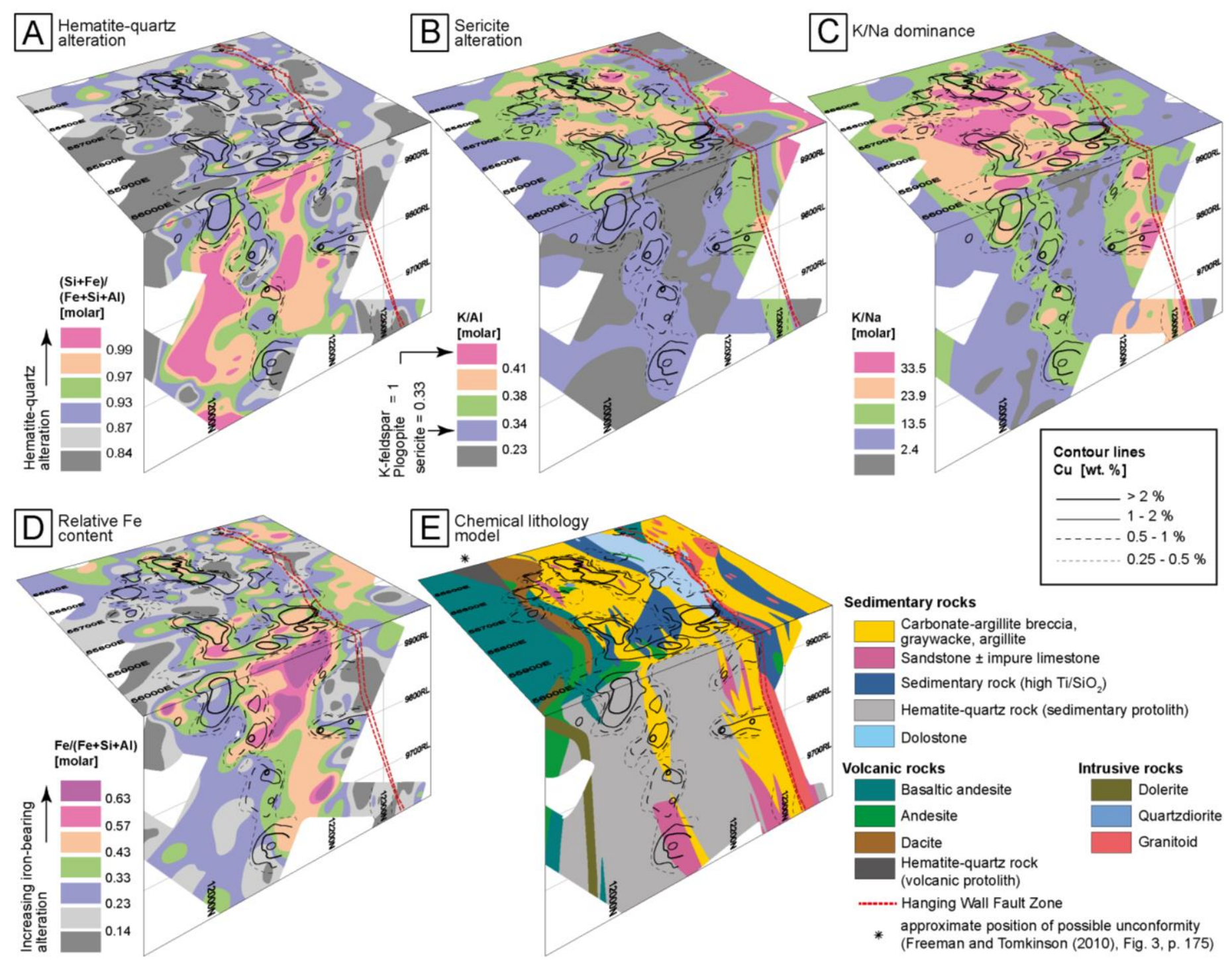

Fig. 21. Block diagrams made from sections $56050 \mathrm{mE} \pm 25 \mathrm{~m}$ and $9950 \mathrm{mRL} \pm 25 \mathrm{~m}$ showing effects of combined alteration and lithology control on Cu mineralization at Prominent Hill. Diagrams show Cu grade distribution (black contours with isograds of $0.5,1,2$, and $>2 \mathrm{wt} \% \mathrm{Cu}$ ) in relation to: (A) Hematite-quartz alteration, (B) hematitechlorite-sericite alteration, (C) K/Na dominance, (D) relative Fe content, and (E) chemical lithology distribution model from Figure 17. 

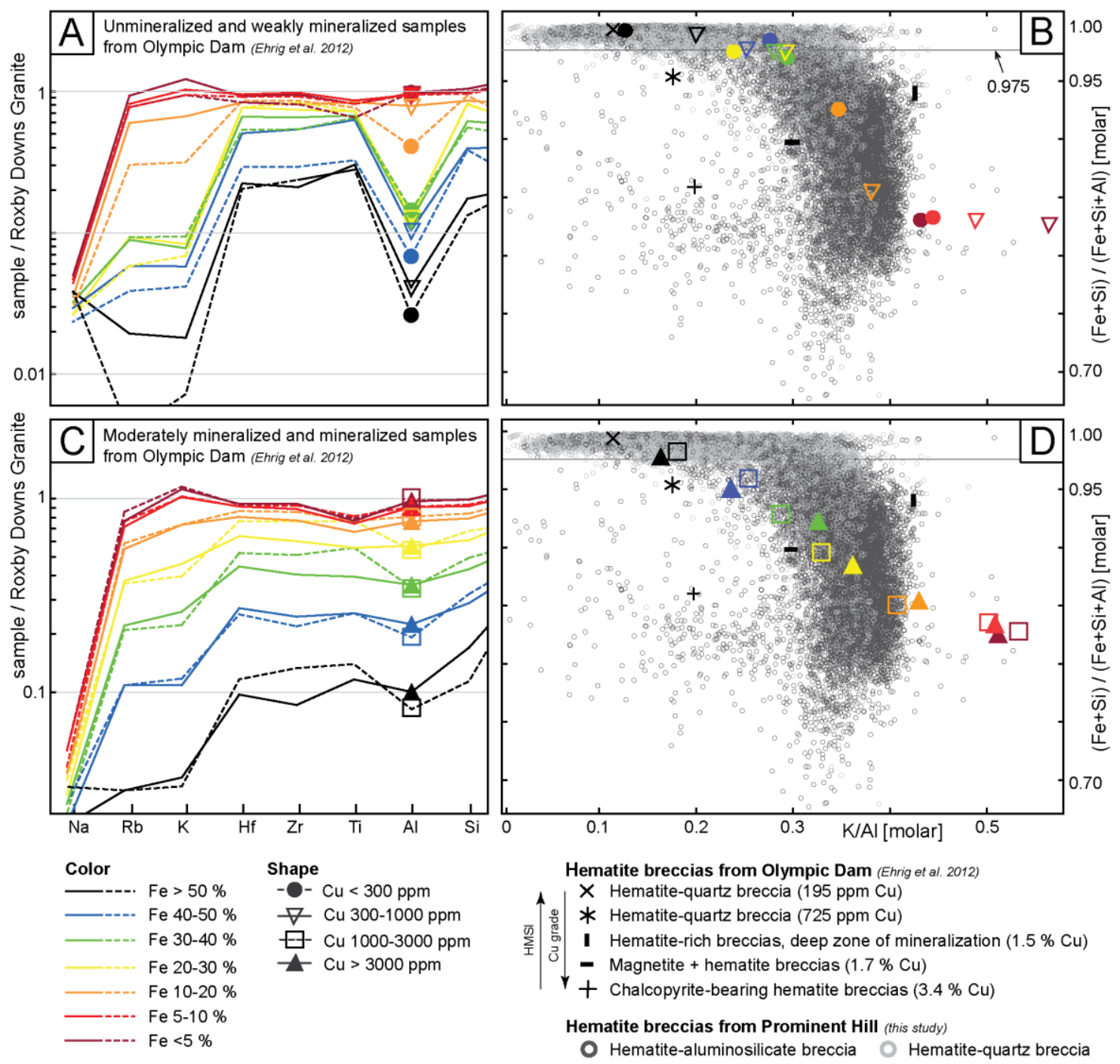

Fig. 22. Comparison between average compositions of 10,000 samples from iron oxide-altered rocks at Olympic Dam (Ehrig et al., 2012) and data for the hematite breccia body at Prominent Hill. (A) Data normalized to Roxby Downs Granite (RDG) showing effects of iron oxide alteration on individual granite-derived elements introduced by the hydrothermal system for (A) unmineralized $(\mathrm{Cu}<300 \mathrm{ppm}$ ) and weakly mineralized ( $\mathrm{Cu} 300-1000 \mathrm{ppm}$ ) samples. (B) Diagram showing molar K/Al ratio vs. Hematite Quartz Alteration Index (HMSI value) of data from (A) including average composition of hematite breccia at Olympic Dam overlain with data from the hematite breccia body at Prominent Hill. (C, D) Equivalent to (A, B) but plotted for data from moderately mineralized ( $\mathrm{Cu} 1000-3000 \mathrm{ppm})$ and mineralized $(\mathrm{Cu} \geq 3000 \mathrm{ppm})$ breccias from Olympic Dam (see text for discussion).

\subsection{Host rocks}

The original sedimentary host rocks contained abundant carbonate, as evidenced by the presence of relict massive dolostone in the deposit, calc-silicates and marbles north of the deposit, and by calcareous-argillaceous lithologies in likely equivalent sedimentary rock packages outside the Prominent Hill area (Fig. 1C; Freeman and Tomkinson, 2010). The host rock package of interbedded and brecciated carbonate-argillite, graywacke, argillite breccias, sandstone, and minor mafic to intermediate-composition volcanic rocks is consistent with deposition in a continental and perhaps mildly evaporitic (dolomite), magmatically and tectonically active basin (Fig. 23A). The $\mathrm{Cu}-\mathrm{Au}$ mineralization is hosted mainly by sedimentary rocks and lesser volcanic rocks that would have contained abundant alteration-reactive constituents such as carbonates (Fig. 6) or feldspars (Fig. 7), both being suitable for later hydrolysis to form hydrothermal sericite and chlorite. 
The precise age of the sedimentary host rocks is unknown. Freeman and Tomkinson (2010) correlated the metasedimentary rocks north of the HWFZ with the $\sim 1750$ Ma Wallaroo Group and speculated that the seimentary host rocks south of the HWFZ may represent younger rocks having ages of $\sim 1590$ to $\sim 1580$ Ma. Alternatively, the sedimentary host rocks might be less-metamorphosed or reworked equivalents of the Wallaroo Group, which is regionally intruded by rocks of the $1595-$ 1575 Ma GRV-Hiltaba Suite Similar host rocks contain economic $\mathrm{Cu}$ mineralization not only at Prominent Hill but also at the Hillside IOCG deposit (Conor, 1995; Conor et al., 2010; Porter, 2010b). Moreover, Wallaroo Group-equivalent metasedimentary rocks are present in other IOCG prospects and deposits such as Emmie Bluff (Gow et al., 1994), Murdie-Murdie, Titan, and Torrens Dam (Bastrakov et al., 2007). We infer that carbonate-bearing sedimentary rocks of Wallaroo Group age, and/or reworked Wallaroo Group strata that were intruded by magmas of Hiltaba Suite-GRV-age (Fig. 23B), represent important host rocks for IOCG mineralizing systems throughout the Olympic IOCG province (Fig. 1A).

\section{$S$}
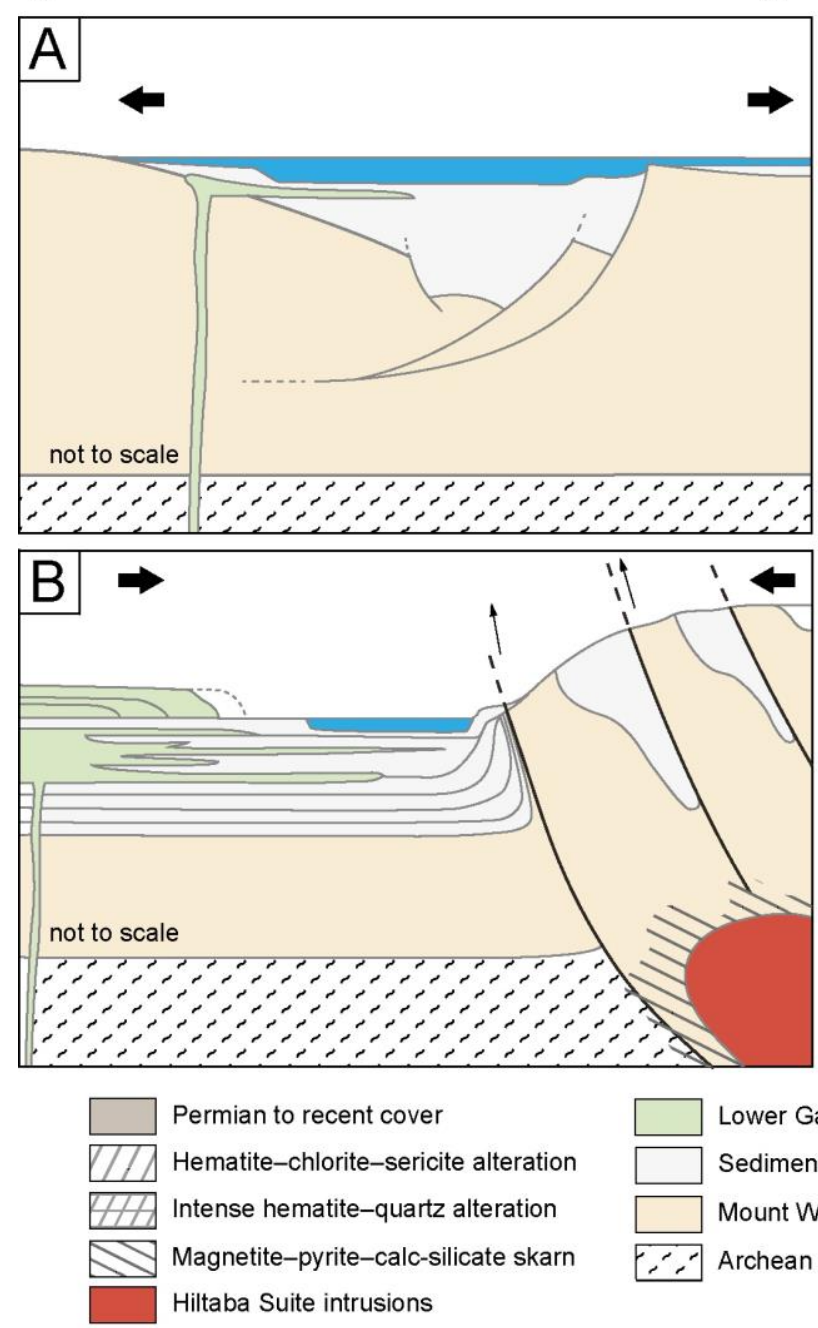

Permian to recent cover

Hematite-chlorite-sericite alteration

ntense hematite-quartz alteration

Magnetite-pyrite-calc-silicate skarn

Hiltaba Suite intrusions
$\mathrm{N}$
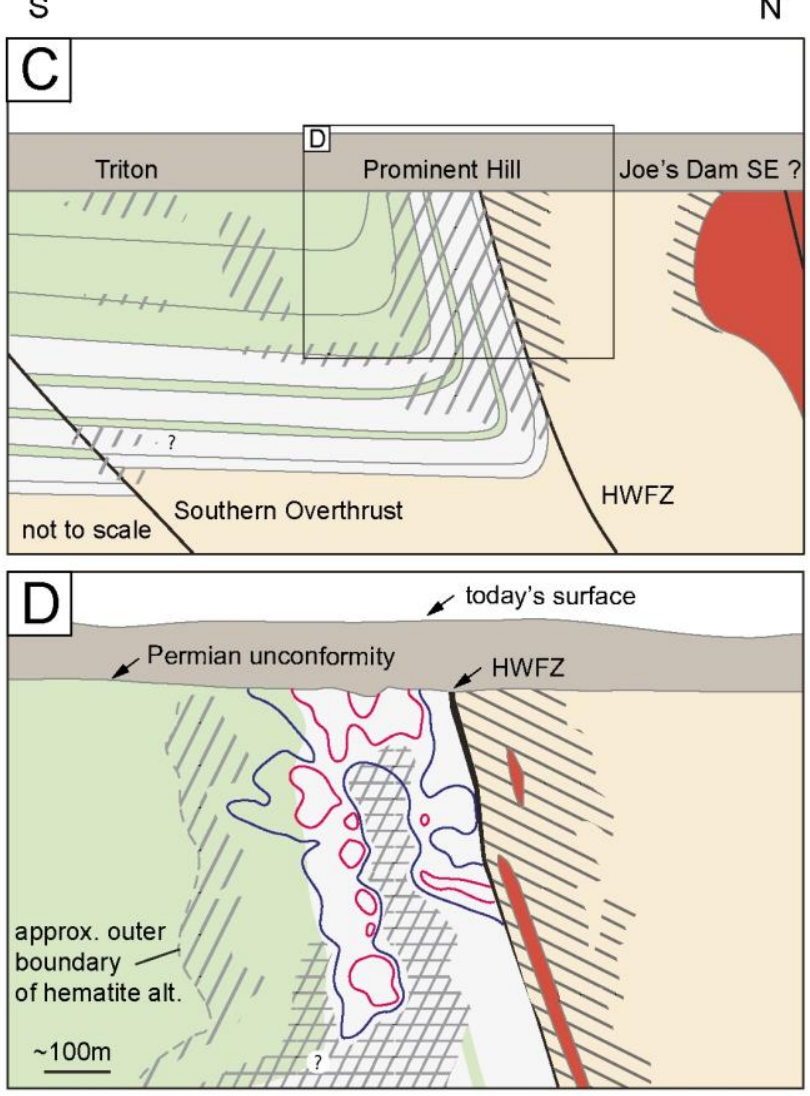

Fig. 23. Proposed sequence of events that led to the formation of the Prominent Hill deposit. (A) Sedimentation of host rock package and extrusion of lower Gawler Range Volcanics (GRV) possibly including depositional to diagenetic brecciation. (B) Continued extrusion of volcanics, intrusion of comagmatic Hiltaba Suite, and regional metamorphism within Mount Woods inlier during compression, tilting, and brecciation of host rock package. (C) Area of Prominent Hill after compression, intrusion of subvolcanic dikes, alteration, and mineralization, followed by exhumation, erosion, and deposition of postPermian cover sequence. (D) Simplified cross section ( $\sim 56050 \mathrm{~m} \mathrm{E})$ through the deposit area, showing upward-convex alteration profile and $\mathrm{Cu}$ precipitation front defining current economic orebodies. 


\subsection{Geometric and structural controls on mineralization}

Clastic sedimentary rocks (Coodambana metaconglomerate) unconformably overlie a potential early-stage Hiltaba-GRV-age depositional hiatus that may extend across the Mount Woods inlier into the area of Prominent Hill. This interpretation is supported by the possible unconformity (Freeman and Tomkinson, 2010, fig. 3, p. 175) between the lower GRV (Carter et al., 2003; Belperio et al., 2007; Harris et al., 2013) and sedimentary host rocks at Prominent Hill. A regionally compressive phase late in the evolution of the GRV igneous province is recorded in the Mount Woods inlier and in adjacent Proterozoic terranes (Page et al., 2005; Betts et al., 2006; Giles et al., 2006; Payne et al., 2006, 2008; Cutts et al., 2011; Forbes et al., 2011, 2012; Armit et al., 2014).

Deposition of the Coodnambana metaconglomerate took place in a high-energy topographic setting like a valley (Chalmers, 2007) that may have changed into a fault-bounded basin in the southern Mount Woods domain (Fig. 23A; Belperio et al., 2007). Crustal shortening and deformation (Forbes et al., 2011) occurred after (or during) deposition of the clastic sediments (Chalmers, 2007). Subsequently, the Prominent Hill host rock package was overturned (Forbes et al., 2012) along the Hanging Wall Fault Zone and the Southern Overthrust, which separates the orogenic front from essentially flat-lying strata of the GRV further south (Harris et al., 2013; Fig. 23B). Geopetal structures (Fig. 13) show that brecciation, hematite alteration, and high-grade chalcocite-bornite deposition occurred syn-tectonically during and after rotation of the host rock package. The geometric controls that localized the Prominent Hill orebodies are probably a combination of stratigraphy (possible unconformities; Freeman and Tomkinson, 2010, Fig. 3, p. 175) and block rotation from reverse faulting (e.g., Simpson, 2010). Geochronological data (Jagodzinski, 2005; Belperio et al., 2007; Skirrow et al 2007; Forbes et al., 2012) indicate that $\mathrm{Cu}-\mathrm{Au}$ mineralization at Prominent Hill was broadly contemporaneous with the intrusion of the Hiltaba Suite and the exhumation of the Mount Woods inlier (see below). Thus, any north-side-up movement along the HWFZ likely was synchronous with, or followed, the onset of high-grade mineralization (Fig. 23B-C).

\subsection{Hematite alteration, replacement, and mineralization}

Economic $\mathrm{Cu}$-(Fe)-sulfide mineralization at Prominent Hill is strata-bound and appears to follow geochemically mappable lithostratigraphic units, but is concentrated on a discordant front of alteration and mineralization (Figs. 21, 23D). The hematite alteration is zoned, showing variations from hematite-quartz $\pm \mathrm{Au}$ to transitional hematite-chlorite-sericite including $\mathrm{Cu}$-(Fe)-sulfide mineralization (Fig. 23D). These two pervasive alteration varieties correlate with the local distribution of $\mathrm{Cu}$. The transition from hematite \pm quartz-dominant alteration can be mapped using the HMSI value (Fig. 18), which correlates inversely with $\mathrm{Cu}$ grade. Spatial variations of other alteration indices, including molar $\mathrm{K} /(2 \mathrm{Ca}+\mathrm{Na}+\mathrm{K}), \mathrm{K} / \mathrm{Al}$, and $\mathrm{K} / \mathrm{Na}$ ratios (Fig. 20), show that alteration gradients in the stability field of white mica solid solutions are correlated with economic $\mathrm{Cu}$ mineralization (Figs. 19-21). Distal from $\mathrm{Cu}$-poor zones of intense hematite-quartz alteration (Fig. 21), hematite-chlorite-sericite alteration with high $\mathrm{Cu}$ grades can be mapped using molar K-Na-Al ratios (Fig. 20).

The inferred carbonate dissolution and widespread hematite replacement is likely associated with net mass loss $\left(\mathrm{CaO}, \mathrm{Na}_{2} \mathrm{O}\right.$, and variable $\mathrm{CO}_{2}, \mathrm{Al}_{2} \mathrm{O}_{3}$; Fig. 14). This process led to increases in porosity and permeability (Fig. 6), which may have contributed to the brecciation that made the deposit area susceptible to increased fluid penetration over time. In contrast, the hematite-quartzalteration in the breccia is characterized by local reduction of porosity due to major addition of $\mathrm{Fe}_{2} \mathrm{O}_{3}$ $\left( \pm \mathrm{SiO}_{2}\right)$ (Figs. 8, 14B). Nevertheless, this altered breccia must have been sufficiently permeable to act as major focus for the influx of acid fluids, controlling the overall permeability structure of the breccia body and leading to $\mathrm{Cu}$ precipitation from an initially acidic and $\mathrm{Cu}$-bearing fluid, as a result of acidneutralization by chlorite-sericite-hematite alteration. The distribution of HMSI values (e.g., section $9950 \mathrm{mRL}$, Fig. 21) can therefore be used as an exploration vector to high-grade ore. The onset of 
hematite-quartz alteration is partly controlled by structural and/or stratigraphic contacts, as indicated by the sharp increase in the HMSI value between the inferred lower GRV (Belperio et al., 2007) and abundantly mineralized sedimentary rocks (Figs. 17 and 21).

The range of HMSI values record the degree of $\mathrm{Na}, \mathrm{K}$, and $\mathrm{Al}$ depletion relative to iron oxide \pm quartz addition. In fact, data for the sub-arkose reference sample and two altered sandstones from Prominent Hill show that the intensely altered equivalents not only have higher HMSI values (Fig. 18B) but also lower $\mathrm{Al} / \mathrm{Ti}$ ratios, compared with their unaltered references (Figs. 14E, 16A). This inverse correlation justifies the interpretation that data defining clusters S4 and V5 (Fig. 15B, C) do not represent distinct lithologies. The limbs in Figure 19 reflect the gradual change from rocks containing sericite and chlorite to hematite+quartz. Mineralogical evidence for the replacement of aluminosilicates is documented in Figures 4, 7, and 9A. Similarly, hematite-replaced aluminosilicate minerals occur at Olympic Dam (Oreskes and Einaudi, 1990; Ehrig et al., 2012).

The hematite-quartz alteration and its influence on the HMSI value also provide a plausible explanation for the Al-depletion (relative to $\mathrm{Ti}, \mathrm{Hf}$ and $\mathrm{Zr}$ ) in many Fe-rich rocks at Olympic Dam (Fig. 22). The degree of depletion for Roxby Downs Granite-derived elements including $\mathrm{Na}, \mathrm{Rb}, \mathrm{K}, \mathrm{Hf}, \mathrm{Zr}$, $\mathrm{Ti}, \mathrm{Al}$ and Si increases with increasing Fe concentration (cf. Ehrig et al., 2012). The generally greater relative depletions of $\mathrm{Na}, \mathrm{Rb}$ and $\mathrm{K}$ reflect hydrothermal leaching, coupled with the effects of the net mass gain due to Fe addition. As at Prominent Hill, barren to weakly $\mathrm{Cu}$ mineralized and Fe-rich rocks are increasingly Al-depleted (Fig. 22A) and show a trend towards HMSI = 1 (Fig. 22B). For moderately mineralized rocks, the relative Al decrease is not as significant (Fig. 22C), but these rocks consistently show higher HMSI values than the mineralized rock group (Fig. 22D). In addition, average compositions for various breccia types from Olympic Dam indicate that higher $\mathrm{Cu}$ grades can be expected in rocks with low HMSI values (Fig. 22D). Another similarity between Prominent Hill and Olympic Dam appears in the spatial distribution of intense hematite-quartz alteration. Despite local exceptions that occur throughout both deposits, hematite-quartz breccias formed within a central, high-intensity alteration zone and are commonly bound by $\mathrm{Cu}$ mineralized, bornite- and chalcociterich, hematite-aluminosilicate breccias (Figs. 21, 23D; Ehrig et al., 2012, Figs. 4, 6, and 14).

Texturally late covellite and chalcocite that replace early $\mathrm{Cu}$-(Fe)-sulfides and pyrite (Belperio et al., 2007; Schlegel, 2010) can potentially form by supergene enrichment. Such Cu enrichment records oxygenated and acidic surface fluids that leach the fully-oxidized surficial part of an orebody in the vadose zone, and reprecipitate copper as low-sulfur $\mathrm{Cu}$-sulfide minerals in subjacent secondary enrichment blankets (e.g., Sillitoe, 2005). The formation of chalcocite ores at Prominent Hill probably did involve fluids with a high concentration ratio of copper to reduced sulfur, but the upward-convex geometry of the alteration and mineralization front indicates hydrothermal fluid upflow and some lateral fluid flow, rather than downward infiltration of groundwaters (Fig. 18). Moreover, $\mathrm{Cu}-(\mathrm{Fe})-$ sulfide-associated fluid inclusion assemblages (including syn-ore fluorite) homogenize between $\sim 145^{\circ} \mathrm{C}$ and $\sim 330^{\circ} \mathrm{C}$ (Schlegel, 2010 , and unpublished data), thus indicating that the chalcocite- and bornite-rich mineralization formed at hydrothermal temperatures. The Prominent Hill deposit is truncated by a glacial erosion surface of Permian age, and overlying but now eroded parts of the orebody may well have been exposed to weathering between Middle Proterozoic and Permian times. However, the spatial distribution of sulfide assemblages in the preserved upper part of the orebody (Fig. 11) is inconsistent with supergene enrichment from above. The distribution of chalcocite assemblages follows the upward-convex aluminosilicate alteration front (Figs. 18 and 21), and chalcocite replacement textures occur down to the deepest sample depths ( $500 \mathrm{~m}$ below the erosion surface), and pyrite and chalcopyrite assemblages in chlorite-sericite-bearing ore can be observed within centimeters of the glacial erosion surface.

Models for the origin of hematite-associated IOCG deposits imply that pyrite-rich halos surrounding magnetite-bearing alteration zones were important in providing a source of abundant sulfur for later $\mathrm{Cu}$ sulfide mineralization. Pyrite that formed prior to $\mathrm{Cu}$ mineralization is a potential source of sulfur within IOCG systems, which are typically sulfide deficient (e.g., Chen, 2013). Besides the zoned alteration (Fig. 21), the incorporation of earlier pyrite is considered critical in the genesis 
of Cu-sulfide mineralization at Prominent Hill, because $\mathrm{Cu}$-rich sulfides commonly replace pyrite in the hematite-aluminosilicate breccia (Belperio et al., 2007; Schlegel, 2010). If structurally-enhanced hydrothermal fluid flow discharges fluid into thicker-bedded, calcareous (meta-) sedimentary rocks, argillaceous or pelitic beds may act as aquitards, resulting in fluid focusing. In this respect, pyritebearing sedimentary lithologies may represent prospective IOCG exploration targets that may not be detectable by aeromagnetic surveys.

\subsection{Timing of alteration and mineralization}

The Engenina Adamellite ( 1692 Ma; Fanning, 1997; Daly et al., 1998) and the magnetite \pm pyrite \pm chalcopyrite-bearing alteration that is probably related to emplacement of the Hiltaba Suite intrusions ( $\sim 1595$ to $\sim 1575$ Ma; Fanning et al., 1988; Fanning, 1997; Betts et al., 2003; Fanning et al., 2007; Hand et al., 2007) at least partly pre-date economic $\mathrm{Cu}-\mathrm{Au}$ ore formation. This conclusion is based on the interpretation that apparently GRV-equivalent rocks are hematite-altered and mineralized at Prominent Hill (Belperio et al., 2007) and elsewhere in the deposit area (Carter et al., 2003; Harris et al., 2013).

Magnetite-pyrite-rich alteration (Fig. 2) in the Mount Woods domain occurred during several events. The timing of the magnetite-albite-calc-silicate alteration is bracketed by the age of gabbro crystallization ( $1587 \mathrm{Ma}$; Jagodzinski, 2005), and by the age of likely contact metamorphism-related magnetite-pyrite-pyrrhotite-chalcopyrite mineralization at Peculiar Knob ( 1576 Ma; Jagodzinski, 2005) that overlaps the age of vein titanite at Manxman West (1567 $\pm 10 \mathrm{Ma}$, U-Pb SHRIMP; Skirrow et al., 2007), representing the local minimum age of magnetite-bearing alteration. These ages overlap with those of Hiltaba Suite and GRV magmatism between 1604 and 1575 Ma (Fanning et al., 1988; Fanning, 1997; Fanning et al., 2007; Hand et al., 2007) and with peak metamorphism between 1615 and $\sim 1590$ Ma (Forbes et al., 2011), which possibly extended until 1576 Ma. Forbes et al. (2011) concluded that the metamorphism was associated with intrusion of the Hiltaba Suite. According to Forbes et al. (2012), the $\mathrm{Cu}$ mineralization at Prominent Hill was potentially associated with initial exhumation of the Mount Woods inlier, starting between $\sim 1592$ and 1582 Ma.

Hematite alteration and $\mathrm{Cu}$ mineralization at Prominent Hill post-dates deposition of the lower GRV (Carter et al., 2003; Belperio et al., 2007; Harris et al., 2013), based on the presence of alteration and mineralization of the volcanic rocks proximal to the deposit (Fig. 23C, D). Repeated high-grade mineralization by $\mathrm{Cu}$-rich sulfides occurred late at Prominent Hill (Fig. 12); hematite-stable conditions post-dated (or at least outlasted) the magnetite skarn stage. There is little evidence for large-scale replacement of magnetite by hematite, other than the formation of martite North of the HWFZ, indicating a fluctuation of redox conditions or the conversion of magnetite to hematite by acidic fluids of intermediate to low temperature (Ohmoto, 2003; Otake et al., 2007). Within the hematite breccia body, replacement of magnetite to hematite is rare and textures show that the bulk of the hematite was precipitated directly from a hydrothermal fluid.

\section{Conclusions and Exploration Implications}

- The Prominent Hill $\mathrm{Cu}-\mathrm{Au}$ deposit is hosted by hematite-altered, brecciated, steeply dipping sedimentary rocks and structurally underlying mafic to intermediate-composition volcanic rocks inferred to be part of the Gawler Range Volcanics large igneous province. Geopetal markers indicate that economic $\mathrm{Cu}$ mineralization occurred after tilting of the host rock package into the present orientation, and therefore is younger than deposition of the lower Gawler Range Volcanics.

- $\mathrm{Cu}-(\mathrm{Fe})$-sulfides at Prominent Hill are within a predominantly unmetamorphosed sedimentary package including brecciated, carbonate-rich and/or feldspar-bearing host rocks that had a capacity to neutralize acidic fluids. Besides Prominent Hill, many other prospects and deposits in the Olympic IOCG province are at least partly hosted by (meta)sedimentary rocks of similar age and character, and are invariably in contact with volcanic or intrusive equivalents of the Gawler 
Range Volcanics and Hiltaba Suite. Large-scale exploration should therefore consider both lithostratigraphic controls (permeable feldspathic \pm carbonate sediments adjacent to magmatic rocks) and structural controls (faulting and block rotation).

- The $\mathrm{Cu}$ mineralization is broadly strata-bound, constrained by geochemically mappable lithostratigraphy, and exists outside a discordant hematite-quartz alteration front. Most of the zones of higher $\mathrm{Cu}$ ore grade occur within hematite-chlorite-sericite-altered breccias that also contain siderite, fluorite, and barite.

- The hematite-quartz alteration index (HMSI value, defined as the molar [Fe+Si]/[Fe+Si+Al] ratio) can be used to map the transition of strong hematite-quartz alteration to moderate hematitechlorite-sericite alteration, and provides a local mapping vector towards high-grade $\mathrm{Cu}$ ore. The most intense hematite-quartz alteration (high HMSI value) was texturally destructive and resulted in Al-depletion and reduced porosity in the breccias. This alteration generated a weakly Au-enriched but $\mathrm{Cu}$-poor zone inside the front of highest-grade $\mathrm{Cu}$ mineralization, bordering the surrounding hematite-chlorite-sericite-altered rocks.

- This study has potential exploration applications in delineating high $\mathrm{Cu}$ grades within other hematite-type IOCG deposits in similar geologic and alteration settings, using molar element ratios such as $(\mathrm{Fe}+\mathrm{Si}) /(\mathrm{Fe}+\mathrm{Si}+\mathrm{Al}), \mathrm{K} /(2 \mathrm{Ca}+\mathrm{Na}+\mathrm{K}), \mathrm{K} / \mathrm{Al}$, and $\mathrm{K} / \mathrm{Na}$ as determined from prospect-scale assay data.

- Magnetite-dominant replacement bodies are abundant in the Mount Woods domain. This mildly reducing alteration occurred before, during, and after brecciation of regional (meta)sedimentary rocks and was more directly linked with emplacement of mafic and felsic intrusions related to the Hiltaba Suite-Gawler Range Volcanics. This alteration provided a source of reduced sulfur in the form of pyrite and some chalcopyrite, which may have contributed to subsequent economic $\mathrm{Cu}$ mineralization. The more oxidized, hematite-stable alteration post-dated, or at least outlasted, the reduced magnetite-bearing alteration, but partly pre-dated the deposition of bornite-chalcocite-chalcopyrite-digenite- and idaite-rich ores at Prominent Hill.

\section{Acknowledgments}

This study was funded by Swiss Science National Funds (SSNF) Project 200020-135302/1 and by OZ Minerals during extended periods of work at Prominent Hill, as part of the senior author's Ph.D. thesis. This study would not have been possible without the help of Mark Allen, Marcel Van Eck, and Hamish Freeman, who provided access to mine data, drill core, and extensive practical and intellectual support during several site visits. For their great support we thank the entire OZ Minerals team including exploration geologists Camla Rochat, Ian Anderson, Ricardo Brigante, Paul Hehuwat, Richard Barrat, and Mick Sawyer, external consultants Markus Tomkinson and Stuart Bull, and the field technician teams of Mark Zanker, Peter Keepence, Jay Craker, and others. Dave Lawie is thanked for access to the ioGAS software. Thomas Wagner and Mark Barton contributed valuable discussion points during progress and defense of the Ph.D. thesis. Special thanks are due to Patrick Williams for numerous comments that helped significantly to improve the clarity of this contribution. Roger Skirrow, an anonymous referee, and John Slack are thanked for reviewing the manuscript.

\section{References}

Agangi, A., Kamenetsky, V. S., and McPhie, J., 2012, Evolution and emplacement of high fluorine rhyolites in the Mesoproterozoic Gawler silicic large igneous province, South Australia: Precambrian Research, v. 208, p. 124-144.

Allen, S. R., McPhie, J., Ferris, G., and Simpson, C., 2008, Evolution and architecture of a large felsic igneous province in western Laurentia: The 1.6 Ga Gawler Range Volcanics, South Australia: Journal of Volcanology and Geothermal Research, v. 172, p. 132-147. 
Allen, S. R., Simpson, C. J., McPhie, J., and Daly, S. J., 2003, Stratigraphy, distribution and geochemistry of widespread felsic volcanic units in the Mesoproterozoic Gawler Range Volcanics, South Australia: Australian Journal of Earth Sciences, v. 50, p. 97-112.

Ambrose, G. J., and Flint, R. B., 1981, Billa Kalina, South Australia, Explanatory Notes 250 000: Geological Survey of South Australia, Geological Series, Sheet SH/53-7.

Armit, R. J., Betts, P. G., Schaefer, B. F., Pankhurst, M. J., and Giles, D., 2014, Provenance of the early Mesoproterozoic Radium Creek Group in the northern Mount Painter inlier: Correlating isotopic signatures to inform tectonic reconstructions: Precambrian Research, v. 243, p. 63-87.

Bastrakov, E. N., Skirrow, R. G., and Davidson, G. J., 2007, Fluid evolution and origins of iron oxide- $\mathrm{Cu}-\mathrm{Au}$ prospects in the Olympic Dam district, Gawler craton, South Australia: Economic Geology, v. 102, p. 1415-1440.

Belperio, A. P., 2002, The Prominent Hill copper-gold discovery; exploration strategies for world-class iron-oxide Cu-Au deposits [abs]: Geological Society of Australia Abstracts, v. 67, p. 257.

Belperio, A., and Freeman, H., 2004, Common geological characteristics of Prominant Hill and Olympic Dam: Implications for iron oxide copper-gold exploration models: The AusIMM Bulletin, v. 1990, p. 67-70, 72-75.

Belperio, A., Flint, R., and Freeman, H., 2007, Prominent Hill: A hematite-dominated, iron oxide copper-gold system: Economic Geology, v. 102, p. 1499-1510.

Betts, P. G., Giles, D., Mark, G., Lister, G. S., Goleby, B. R., and Ailleres, L., 2006, Synthesis of the Proterozoic evolution of the Mt Isa inlier: Australian Journal of Earth Sciences, v. 53, p. 187-211.

Betts, P. G., Valenta, R. K., and Finlay, J., 2003, Evolution of the Mount Woods inlier, northern Gawler craton, southern Australia: An integrated structural and aeromagnetic analysis: Tectonophysics, v. 366, p. 83-111.

Blissett, A. H., Creaser, R. A., Daly, S. J., Flint, R. B., and Parker, A. J., 1993, Gawler Range Volcanics, in Drexel, J. F., Preiss, W. V., and Parker, A. J., eds., The geology of South Australia. The Precambrian, 1: Geological Survey of South Australia Bulletin 54, p. 107-126.

Carter, D., Belperio, T., and Freeman, H., 2003, The discovery of the Prominent Hill copper-gold deposit, South Australia: NewGenGold-Case histories of discovery: Perth, Lothean Media, 15 p.

Chalmers, N. C., 2007, Mount Woods domain: Proterozoic metasediments and intrusives: South Australia Department of Primary Industries and Resources, Report Book 2007/20, 78 p.

Chen, H. Y., 2013, External sulphur in IOCG mineralization: Implications on definition and classification of the IOCG clan: Ore Geology Reviews, v. 51, p. 74-78.

Ciobanu, C. L., Wade, B. P., Cook, N. J., Schmidt Mumm, A., and Giles, D., 2013, Uranium-bearing hematite from the Olympic Dam Cu-U-Au deposit, South Australia: A geochemical tracer and reconnaissance $\mathrm{Pb}-\mathrm{Pb}$ geochronometer: Precambrian Research, v. 238, p. 129-147.

Conor, C., 1995, Moonta-Wallaroo region: An interpretation of the geology of the Maitland and Wallaroo 1:100 000 sheet areas: Adelaide, South Australia Department of Primary Industries and Resources Open file envelope 8886.

Conor, C., Raymond, O., Baker, T., Teale, G., Say, P., and Lowe, G., 2010, Alteration and mineralisation in the Moonta-Wallaroo copper-gold mining field region, Olympic domain, South Australia, in Porter, T. M., ed., Hydrothermal iron oxide copper-gold \& related deposits: A global perspective: Adelaide, PGC Publishing, v. 3, p. 147-170.

Cowley, W. M., Conor, C. H. H., and Zang, W. L., 2003, New and revised Proterozoic stratigraphic units on the northern Yorke Peninsula: MESA Journal, v. 29, p. 46-58.

Cox, K. G., Bell, J. D., and Pankhurst, R. J., 1979, The interpretation of igneous rocks: London, George Allen \& Unwin, 445 p.

Creaser, R. A., 1995, Neodymium isotopic constraints for the origin of Mesoproteroroic felsic magmatism, Gawler craton, South Australia: Canadian Journal of Earth Sciences, v. 32, p. 460-471.

Creaser, R. A., 1996, Petrogenesis of a Mesoproterozoic quartz latite-granitoid suite from the Roxby Downs area, South Australia: Precambrian Research, v. 79, p. 371-394. 
Creaser, R. A., and White, A. J. R., 1991, Yardea Dacite — Large-volume, high-temperature felsic volcanism from the Middle Proterozoic of South Australia: Geology, v. 19, p. 48-51.

Cutts, K., Hand, M., and Kelsey, D. E., 2011, Evidence for early Mesoproterozoic (ca. 1590 Ma) ultrahigh-temperature metamorphism in southern Australia: Lithos, v. 124, p. 1-16.

Daly, S. J., Fanning, C. M., and Fairclough, M. C., 1998, Tectonic evolution and exploration potential of the Gawler craton, South Australia [abs]: Geological Society of Australia Abstracts, v. 49, p. 104.

Ehrig, K., McPhie, J., and Kamenetsky, V., 2012, Geology and mineralogical zonation of the Olympic Dam iron oxide Cu-U-Au-Ag deposit, South Australia, in Hedenquist, J. W., Harris, M., and Camus, F., eds., Geology and genesis of major copper deposits and districts of the world: A tribute to Richard H. Sillitoe: Economic Geology Special Publication 16, p. 237-267.

Fanning, C. M., 1997, Geochronological synthesis of southern Australia. Part 2. The Gawler craton: South Australia Primary Industries and Resources, Open File Envelope No. 8918.

Fanning, C. M., Reid, A. J., and Teale, G. S., 2007, A geochronological framework for the Gawler craton, South Australia: South Australia Geologial Survey Bulletin 55, 258 p.

Fanning, C. M., Flint, R. B., Parker, A. J., Ludwig, K. R., and Blissett, A. H., 1988, Refined Proterozoic evolution of the Gawler craton, South Australia, through U-Pb zircon geochronology: Precambrian Research, v. 40-41, p. 363-386.

Ferris, G. M., Schwarz, M. P., and Heithersay, P., 2002, The geological framework distribution and controls of Fe-oxide $\mathrm{Cu}-\mathrm{Au}$ mineralisation in the Gawler craton, South Australia. Part I Geological and tectonic framework, in Porter, T. M., ed., Hydrothermal iron oxide copper-gold \& related deposits A global perspective: Adelaide, PGC Publishing, v. 2, p. 9-31.

Flint, R. B., and Benbow, M. C., 1977, Geology of the Mount Woods inlier: South Australia Department of Mines Report Book 77/134, 50 p.

Freeman, H., and Tomkinson, M., 2010, Geological setting of iron oxide related mineralisation in the southern Mount Woods domain, South Australia, in Porter, T. M., ed., Hydrothermal iron oxide copper-gold \& related deposits: A global perspective: Adelaide, PGC Publishing, v. 3, p. 171-190.

Giles, C. W., 1988, Petrogenesis of the Proterozoic Gawler Range Volcanics, South Australia: Precambrian Research, v. 40, p. 407-427.

Giles, D., Betts, P. G., Ailleres, L., Hulscher, B., Hough, M., and Lister, G. S., 2006, Evolution of the Isan orogeny at the southeastern margin of the Mt Isa inlier: Australian Journal of Earth Sciences, v. 53, p. 91-108.

Gow, P. A., Wall, V. J., Oliver, N. H. S., and Valenta, R. K., 1994, Proterozoic iron oxide (Cu-U-AuREE) deposits - Further evidence of hydrothermal origins: Geology, v. 22, p. 633-636.

Grant, J. A., 1986, The isocon diagram - A simple solution to Gresens' equation for metasomatic alteration: Economic Geology, v. 81, p. 1976-1982.

Grant, J. A., 2005, Isocon analysis: A brief review of the method and applications: Physics and Chemistry of the Earth, v. 30, p. 997-1004.

Gresens, R. L., 1967, Composition-volume relationships of metasomatism: Chemical Geology, v. 2, p. 47-65.

Guillong, M., Meier, D. L., Allan, M. M., Heinrich, C. A., and Yardley, B. W. D., 2008, Appendix A6; SILLS; a MATLAB-based program for the reduction of laser ablation ICP-MS data of homogeneous materials and inclusions: Mineralogical Association of Canada Short Course Notes, v. 40, p. 328-333.

Günther, D., von Quadt, A., Wirz, R., Cousin, H., and Dietrich, V. J., 2001, Elemental analyses using laser ablation-inductively coupled plasma-mass spectrometry (LA-ICP-MS) of geological samples fused with Li2B407 and calibrated without matrix-matched standards: Mikrochimica Acta, v. 136, p. 101-107.

Hampton, S., 1997, A study of the paragenesis and controls of Proterozoic (Cu-Fe-Au-REE) mineralisation at the Manxman A1 and Joe's Dam South prospects, Mount Woods inlier, South Australia: Unpublished Honours thesis, James Cook University of North Queensland, Townsville, Queensland, $140 \mathrm{p}$. 
Hand, M., Reid, A., and Jagodzinski, L., 2007, Tectonic framework and evolution of the Gawler craton, southern Australia: Economic Geology, v. 102, p. 1377-1395.

Harris, T. M., Murphy, F. C., Funk, C. W., and Betts, P. G., 2013, Mt Woods 2D seismic reflection survey, Gawler craton, South Australia: An intergrated minerals exploration case study: Melbourne, Australia, CSIRO Publishing, 23rd International Geophysical Conference and Exhibition ASEG-PESA 2013, The eureka moment, p. 1-4.

Haynes, D. W., Cross, K. C., Bills, R. T., and Reed, M. H., 1995, Olympic Dam ore genesis: A fluidmixing model: Economic Geology v. 90, p. 281-307.

Hayward, N., and Skirrow, R. G., 2010, Geodynamic setting and controls on iron oxide $\mathrm{Cu}-\mathrm{Au}(\mathrm{U})$ ore in the Gawler craton, South Australia, in Porter, T. M., ed., Hydrothermal iron oxide copper-gold \& related deposits: A global perspective: Adelaide, PGC Publishing, v. 3, p. 119-146.

Holm, 0., 2004, New geochronology of the Mount Woods inlier and the central Gawler gold province, in Gawler craton: State of play 2004: South Australia Department of Primary Industries and Resources.

Humphris, S. E., Alt, J. C., Teagle, D. A. H., and Honnorez, J. J., 1998, Geochemical changes during hydrothermal alteration of basement in the stockwork beneath the active Tag hydrothermal mound, in Herzig, P. M., Humphris, S. E., Miller, D. J., and Zierenberg, R. A., eds., Proceedings of the Ocean Drilling Program, Scientific Results, v. 158, p. 255-276.

Jagodzinski, E. A., 2005, Compilation of SHRIMP U-Pb geochronological data, Olympic domain, Gawler craton, South Australia, 2001-2003: Record Geoscience Australia, Report \# 2005/20, 220 p.

Jagodzinski, E. A., Reid, A. J., Calmers, N. C., Swain, G., Frew, R. A., and Foudoulis, C., 2007, Compilation of SHRIMP U-Pb geochronological data for the Gawler craton, South Australia: South Australia Department of Primary Industries and Resources, Report Book 2007/21, 224 p.

Johnson, J. P., and Cross, K. C., 1995, U-Pb geochronological constraints on the genesis of the Olympic Dam Cu-U-Au-Ag deposit, South Australia: Economic Geology, v. 90, p. 1046-1063.

Lollo, C., 2013, The Prominent Hill reserves and resources outlook: http://www.ozminerals.com/Media/docs/ASX-131211-Prominent-Hill-Reserves-and-ResourcesStatement-and-Production-Outlook-bb2a4128-adc9-42d2-97df-7a444cc72845-0.pdf OZ Minerals LTD, Melbourne Victoria, Australia.

Lopez-Moro, F. J., 2012, Easygresgrant-A Microsoft Excel spreadsheet to quantify volume changes and to perform mass balance modeling in metasomatic systems: Computers \& Geosciences, v. 39, p. 191-196.

McPhie, J., Kamenetsky, V. S., Chambefort, I., Ehrig, K., and Green, N., 2011, Origin of the supergiant Olympic Dam Cu-U-Au-Ag deposit, South Australia: Was a sedimentary basin involved?: Geology, v. 39, p. 795-798.

Mukherjee, P. K., and Gupta, P. K., 2008, Arbitrary scaling in isocon method of geochemical mass balance: An evaluation of the graphical approach: Geochemical Journal, v. 42, p. 247-253.

Ohmoto, H., 2003, Nonredox transformations of magnetite-hematite in hydrothermal systems: Economic Geology, v. 98, p. 157-161.

Oreskes, N., and Einaudi, M. T., 1990, Origin of rare-earth element-enriched hematite breccias at the Olympic-Dam Cu-U-Au-Ag deposit, Roxby Downs, South Australia: Economic Geology, v. 85, p. 128.

Oreskes, N., and Einaudi, M. T., 1992, Origin of hydrothermal fluids at Olympic Dam: Preliminary results from fluid inclusions and stable isotopes: Economic Geology, v. 87, p. 64-90.

Otake, T., Wesolowski, D. J., Anovitz, L. M., Allard, L. F., and Ohmoto, H., 2007, Experimental evidence for non-redox transformations between magnetite and hematite under $\mathrm{H}_{2}$-rich hydrothermal conditions: Earth and Planetary Science Letters, v. 257, p. 60-70.

Page, R. W., Conor, C. H. H., Stevens, B. P. J., Gibson, G. M., Preiss, W. V., and Southgate, P. N., 2005, Correlation of Olary and Broken Hill domains, Curnamona Province: Possible relationship to Mount Isa and other north Australian Pb-Zn-Ag-bearing successions: Economic Geology, v. 100, p. 663-676. 
Payne, J. L., Barovich, K. A., and Hand, M., 2006, Provenance of metasedimentary rocks in the northern Gawler craton, Australia: Implications for Palaeoproterozoic reconstructions: Precambrian Research, v. 148, p. 275-291.

Payne, J. L., Hand, M., Barovich, K. M., and Wade, B. P., 2008, Temporal constraints on the timing of high-grade metamorphism in the northern Gawler craton: Implications for assembly of the Australian Proterozoic: Australian Journal of Earth Sciences, v. 55, p. 623-640.

Pettijohn, F. J., Potter, P. E., and Siever, R., 1987, Sand and sandstone: New York, SpringerVerlag, $533 \mathrm{p}$.

Pollard, P. J., 2006, An intrusion-related origin for $\mathrm{Cu}-\mathrm{Au}$ mineralization in iron oxide-coppergold (IOGG) provinces: Mineralium Deposita, v. 41, p. 179-187.

Porter, T. M., 2010a, The Carrapateena iron oxide copper gold deposit, Gawler craton, South Australia: A review, in Porter, T. M., ed., Hydrothermal iron oxide copper-gold \& related deposits: A global perspective: Adelaide, PGC Publishing, v. 3, p. 191-200.

Porter, T. M., 2010b, Current understanding of iron oxide associated-alkali altered mineralised systems: Part II - A review, in Porter, T. M., ed., Hydrothermal iron oxide copper-gold \& related deposits: A global perspective: Adelaide, PGC Publishing, v. 3, p. 33-105.

Reeve, J. S., Cross, K. C., Smith, R. N., and Oreskes, N., 1990, Olympic Dam copper-uranium-goldsilver deposit: Australasian Institute of Mining and Metallurgy Monograph Series, v. 14, p. 10091035.

Reid, A., Smith, R. N., Baker, T., Jagodzinski, E. A., Selby, D., Gregory, C. J., and Skirrow, R. G., 2013, Re-Os dating of molybdenite within hematite breccias from the Vulcan $\mathrm{Cu}-\mathrm{Au}$ prospect, Olympic Cu-Au province, South Australia: Economic Geology, v. 108, p. 883-894.

Roberts, D. E., and Hudson, G. R. T., 1983, The Olympic Dam copper-uranium-gold deposit, Roxby Downs, South Australia: Economic Geology, v. 78, p. 799-822.

Rossi, M. E., and Deutsch, C. V., 2014, Mineral resource estimation: Dordrecht, Springer, 332 p.

Schlegel, T. U., 2010, Ore-fluid history of the Prominent Hill iron oxide-copper-gold deposit, South Australia: A reconnaissance fluid inclusion study: Unpublished M.Sc. thesis, Swiss Federal Institute of Technology, ETH Zürich, 66 p.

Schlegel, T. U., Walle, M., Steele-MacInnis, M., and Heinrich, C. A., 2012, Accurate and precise quantification of major and trace element compositions of calcic-sodic fluid inclusions by combined microthermometry and LA-ICPMS analysis: Chemical Geology, v. 334, p. 144-153.

Sillitoe, R. H., 2005, Supergene oxidized and enriched porphyry copper and related deposits: Economic Geology One Hundredth Anniversary Volume, p. 723-768.

Simpson, G. D. H., 2010, Formation of accretionary prisms influenced by sediment subduction and supplied by sediments from adjacent continents: Geology, v. 38, p. 131-134.

Skirrow, R. G., Bastrakov, E., Davidson, G. J., Raymond, O. L., and Heithersay, P., 2002, The geological framework, distribution and controls of Fe-oxide $\mathrm{Cu}$-Au mineralisation in the Gawler craton, South Australia; Part II, Alteration and mineralisation, in Porter, T. M., ed., Hydrothermal iron oxide copper-gold \& related deposits: A global perspective: Adelaide, PGC Publishing, v. 2, p. 3347.

Skirrow, R. G., Bastrakov, E. N., Barovich, K. M., Fraser, G. L., Creaser, R. A., Fanning, C. M., Raymond, O. L., and Davidson, G. J., 2007, Timing of iron oxide $\mathrm{Cu}-\mathrm{Au}-(\mathrm{U})$ hydrothermal activity and $\mathrm{Nd}$ isotope constraints on metal sources in the Gawler craton, South Australia: Economic Geology, v. 102, p. 1441-1470.

Tappert, M. C., Rivard, B., Giles, D., Tappert, R., and Mauger, A., 2013, The mineral chemistry, near-infrared, and mid-infrared reflectance spectroscopy of phengite from the Olympic Dam IOCG deposit, South Australia: Ore Geology Reviews, v. 53, p. 26-38.

Warren, I., Simmons, S. F., and Mauk, J. L., 2007, Whole-rock geochemical techniques for evaluating hydrothermal alteration, mass changes, and compositional gradients associated with epithermal Au-Ag mineralization: Economic Geology, v. 102, p. 923-948. 
Wingate, M. T. D., Campbell, I. H., Compston, W., and Gibson, G. M., 1998, Ion microprobe U-Pb ages for Neoproterozoic basaltic magmatism in south-central Australia and implications for the breakup of Rodinia: Precambrian Research, v. 87, p. 135-159.

Zhao, J.-X., McCulloch, M. T., and Korsch, R. J., 1994, Characterisation of a plume-related $~ 800$ Ma magmatic event and its implications for basin formation in central-southern Australia: Earth and Planetary Science Letters, v. 121, p. 349-367. 


\section{Appendix: Sampling and analytical methods performed in this study}

In total, 31 samples for the hematite - chlorite - sericite to hematite - quartz alteration and magnetite-pyrite altered regional volcanic and sedimentary rock reference samples (Fig. 2, 3) were analyzed for major and trace element concentrations (Table 4, electronic supplementary data). Fused discs were prepared from ground, homogenous rock powders mixed with lithiumtetraborate fluxing agent. Major element oxide concentrations were analyzed by X-ray fluorescence (XRF) analysis using an Axios PANalytical wavelength dispersive spectrometer at ETH Zürich. Trace elements were measured on freshly broken cross sections of XRF disk fragments at ETH Zürich by laser-ablation inductively coupled plasma-mass spectroscopy (LA-ICPMS) using an Eximer $193 \mathrm{~nm}$ laser system with $60 \mu \mathrm{m}$ beam diameter and $10 \mathrm{~Hz}$ repetition rate. Element ratios were measured with an Elan 6100 DRC ICP quadrupole mass spectrometer. The NIST 610 glass was used as an external calibration standard. Post-data acquisition LA-ICPMS signals were processed using SILLS software (Guillong et al., 2008). Reported trace element concentrations are the average of three analyses in different areas of the cullet. The analytical error on reproducibility is $<5 \%$ for concentration above $1 \mathrm{ppm}$ but slightly higher for concentrations below 1 ppm (Günther et al., 2001).

\section{Sampling and analytical methods for assaying}

The following summary originates from the Prominent Hill Resource statement (Lollo, 2013). The drill core used in the assay database were previously geologically logged, mostly photographed and sampled to major lithological and mineralogical contacts on nominal $1 \mathrm{~m}$ intervals permitting sample lengths between 0.4 and $1.4 \mathrm{~m}$. Diamond drill holes were sampled in full extent within the mineralization and host lithologies but only periodically within waste domains. Two field duplicate samples per 40 to 60 samples complemented the sampling protocol. All samples were crushed and pulverized prior analysis. Representative samples were assayed using aqua regia digest, $40 \mathrm{~g}$ fire assay, alkali fusion, mixed acid digest, screen fire assay, glass fusion and inductively coupled plasmamass spectroscopy (ICP-OES). Samples including laboratory duplicates were analyzed for 31 elements or 55 elements, respectively. Analytical pulps are archived onsite. High standard QAQC procedures on assay data were in place and audited frequently at Prominent Hill (Lollo, 2013).

\section{Database extract}

For the purpose of establishing a lithochemical model of the $\mathrm{Cu}$ mineralized basement, an extract of the assay database contained drill holes from Prominent Hill up to the year 2010. The assay database was matched with diamond drill core logging information from three north-south type sections (56050 mE $\pm 25 \mathrm{~m}, 55950 \mathrm{mE} \pm 25 \mathrm{~m}$ and $55650 \mathrm{mE} \pm 25 \mathrm{~m}$ ). Drill holes in these sections were collared through the magnetite-stable hanging wall, the $\mathrm{Cu}$ mineralized hematite breccia body and the footwall volcanic rocks. In addition, one east-west section $(12150 \mathrm{mN} \pm 25 \mathrm{~m})$ and one planar section ( $9950 \mathrm{mRL} \pm 25 \mathrm{~m}$ ) located approximately $150 \mathrm{~m}$ below the basement-cover sequence unconformity were included. The five sections sample $40 \%$ of the exploration drill hole data available between $55300 \mathrm{mE}$ and $56545 \mathrm{mE}$ in east-west, between $8738 \mathrm{mN}$ and $12768 \mathrm{mN}$ in north-south direction and between $10209 \mathrm{mRL}$ and $8738 \mathrm{mRL}$ in depth. In total, 38650 samples were analyzed for their bulk-rock composition and includes in the database extract. The rock intervals are distributed over total $42360 \mathrm{~m}$ logged drill core in a rock volume representing the center of the $\mathrm{Cu}$ mineralized ore body. Approximately $14 \%$ of the database did not contain information for at least one element of $\mathrm{Al}$, Ti or Si. The usually short drill core intervals with missing $\mathrm{Al}, \mathrm{Ti}$, and $\mathrm{Si}$ contents are distributed across the entire reconstruction volume but are concentrated in the magnetite-stable and $\mathrm{Cu}$-poor hanging wall. Data analysis was performed using ioGAS exploratory and geochemical 
data analysis software. Target for ArcGIS was used for alteration calculations and plotting oriented drill hole data which served as a basis for the lithochemical interpretation. 